\title{
El JaRdín JaponÉs en Six JaPanese GaRdenS de KaIJa SaARiaho
}

\section{The Japanese Garden at Six Japanese Gardens by KaIJa SaARIaho}

M. ${ }^{a}$ Dolores Romero Ortiz••

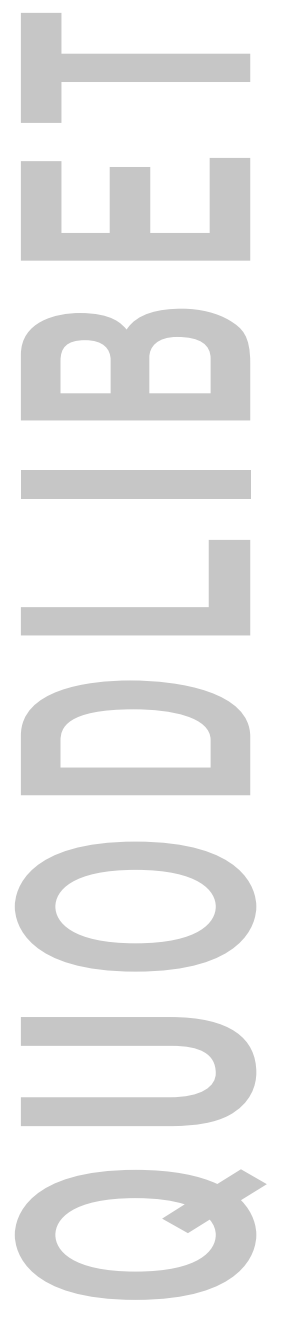

\section{RESUmen}

La obra Six Japanese Gardens (1994) de la compositora finlandesa Kaija Saariaho (1952) es el objeto de estudio de esta investigación como obra significativa no solo en la producción de su autora sino también como visión finisecular de la aplicación de principios estéticos japoneses en obras musicales occidentales.

Una orientación eminentemente analítica permite establecer que los principales fundamentos del jardín japonés (el vacío, la dualidad, la asimetría, la sencillez y la abstracción) se aplican en la composición tanto en la construcción y tratamiento del material como en lo referente a la elección y agrupación instrumental. Además, la simbología actúa de eje vertebrador en las decisiones compositivas ya que afecta tanto al parámetro tímbrico como a la construcción matérica, fundamentada en la aplicación del número tres.

- Esta investigación procede del Trabajo Fin de Máster «Música y jardín. El jardín japonés en Six Japanese Gardens de Kaija Saariaho» realizado por la autora para el Máster Universitario en Interpretación e Investigación Musical de la Universidad Internacional de Valencia (VIU). Fue dirigido por el Dr. Guillermo Aguirre Martínez y leído en febrero de 2020.

- Tecnóloga, compositora y docente. Doctora en Educación Cum Laude por la UNED. Profesora de Fundamentos de Composición por oposición desde 2010.

Ha estrenado varias obras en el Conservatorio de su ciudad natal, Córdoba, en la Fundación Antonio Gala, cuya beca de Jóvenes Creadores obtuvo en el curso 2005/2006, en Madrid, Barcelona, Las Palmas, Alhaurín, Fuengirola y Málaga, destacando sus obras con claras referencias literarias donde se sumerge en la búsqueda de una praxis sonora que aúne música, lenguaje y literatura.

Ha dado conferencias sobre Música Contemporánea, Música Oriental e Historia, y ha participado como ponente en el I Congreso Nacional de Profesores de Análisis y en el II Congreso Nacional de Conservatorios Superiores de Música.

Tiene publicados varios artículos en las revistas Música Oral del Sur, Hoquet, Somos ACIM y Didas@@lia y un libro sobre Música Impresionista.

Recepción del artículo: 10-02-2021. Aceptación del artículo: 19-05-2021. 
Palabras clave: jardín japonés; Kaija Saariaho; simbología; zen.

\section{Abstract}

The piece Six Japanese Gardens (1994) by the Finnish composer Kaija Saariaho (1952) is the subject of study of this research for being a significant work not only in the general production of the composer but also as a turn-of-the-century perspective of the Japanese aesthetics principles in occidental music works.

The material, estructural, timbrical, aesthetic and symbolic analyses will be applied to the original score. This guidance will establish that main foundations of the Japanese garden will be used in the composition in his structural and material treatment and also in the instrumental choice and grouping. Furthermore, the symbolism works as a supporting axis of the composition choices since it will affect timbrical parameters and material structure, based on the appliance of number three.

Key words: Japanese garden; Kaija Saariaho; symbolism; zen.

\section{INTRODUCCIÓN}

El jardín siempre ha sido un elemento que ha fascinado al ser humano. Su contenido simbólico y su espiritualidad han estado presentes en el arte: el Edén de la Biblia, el Jardín de las Hespérides, los Jardines Colgantes de Babilonia o los Jardines de la Alhambra han inspirado a poetas, pintores, literatos y, por supuesto, músicos. El siglo xx ha sido rico en obras musicales con referencias implícitas y explícitas al jardín. Es el caso de Noche en los jardines de España (1915) de Manuel de Falla (1876-1946) o, más próxima en el tiempo, de El jardín de los gozos y las tristezas (1980) de Sofia Gubaidulina (1931). Pero será especialmente entre la década de los 70 y los 90 del siglo pasado cuando los compositores se vuelvan hacia el jardín japonés como fuente de inspiración ${ }^{1}$.

Esta investigación versa sobre una obra emblemática finisecular, Six Japanese Gardens (1994) para percusión y electrónica, de la compositora finlandesa Kaija Saariaho, fruto de un viaje de la autora a Japón y donde se ven reflejados musicalmente los elementos, simbología y contenido de seis jardines japoneses diferentes.

El interés por Japón no es una tendencia novedosa. Japonismo es un término empleado por historiadores y estudiosos para caracterizar la influencia japonesa en Occidente que data de la segunda mitad del siglo xix y principios del siglo xx, y que puede rastrearse desde la literatura, la pintura o la música hasta la publicidad, la moda o la decoración ${ }^{2}$. Esta predilección ha influenciado irremediablemente a

${ }^{1}$ Alfredo Aracil, ed., Música y Jardines (Granada: Archivo Manuel de Falla, 2003), 196.

${ }^{2}$ Menene Gras Balaguer, dir., El jardín japonés: qué es y qué no es entre la espacialidad y la temporalidad del paisaje (Madrid: Tecnos, 2015), 373. 
autores como Vincent Van Gogh (1853-1890), coleccionista de estampas japonesas que «tuvieron un impacto inmediato sobre su pintura, aumentando notablemente el colorido de sus cuadros» ${ }^{3}$ o Claude Monet (1840-1916) cuyo resultado reside en la creación del famoso jardín del artista en Giverny y que sería su fuente de inspiración para sus obras de nenúfares ${ }^{4}$. El Japonismo, en definitiva, ha influido en la evolución del arte occidental, tal como expresa Gras Balaguer:

Cabe quizá aludir al hecho de que la evolución en la estética occidental que parte del impresionismo en pintura, la adopción de principios, motivos y ornamentos naturales en la arquitectura modernista, el minimalismo de la música de Satie, entre otros, no puede desligarse del fenómeno «japonista» como moda artística en la literatura y el arte. ${ }^{5}$

El jardín japonés ha sido uno de los elementos más destacados en esta preferencia por lo japonés, pero su atractivo ha continuado fascinando a lo largo de todo el siglo xx, debido entre otros aspectos a los numerosos puntos de contacto con las concepciones de diferentes artistas de vanguardia cuya obra tendía hacia la abstracción. En palabras de Gras Balaguer:

La sorpresa fue descubrir que el largo proceso hacia la abstracción funcional que Europa había tardado tanto en aceptar y asumir como conveniente expresión de una tradición renovada, en Japón había sobrevenido siglos antes con un grado de sorprendente naturalidad [...] en un jardín de las afueras de Kioto [...], la Villa Katsura, realizada a partir de $1616 .{ }^{6}$

Refiriéndose al jardín de Ryōan-ji, uno de los jardines secos — solo de piedra y grava— más famosos y fuente de inspiración reconocida por autores como John Cage (1912-1992) en su composición homónima Ryōan-ji (1983-1985) o Joan Miró (1893-1983) en Gota de agua sobre la nieve rosa $(1968)^{8}$, Cabañas afirma que es «una constatación de que las diferentes artes no eran compartimentos estancos, y que los materiales que el artista podría utilizar para expresarse podían ser de lo más diverso»?

${ }^{3}$ Gras Balaguer, El jardin japonés..., 372.

${ }^{4}$ Gras Balaguer, El jardín japonés..., 373.

${ }^{5}$ Gras Balaguer, El jardín japonés..., 204.

${ }^{6}$ Gras Balaguer, El jardín japonés..., 522.

${ }^{7}$ Puede escucharse una versión de esta obra interpretada por Carl Rosman (clarinete), Bruce Collings (trombón) y Dick Rothbrust (percusión) en: Ensemble Musikfabrik, «John Cage. Ryoanji», vídeo de You'Tube, 23:48, publicado el 21 de agosto de 2014, https://www.youtube.com/watch?v=TNP3kuu9xvw.

${ }^{8}$ Puede explorarse esta obra en la web de la Fundación Joan Miró: «Fundació Joan Miró», Fundació Joan Miró, acceso el 10 de febrero de 2021, https://www.fmirobcn.org/es/.

${ }^{9}$ Pilar Cabañas Moreno, «Un puente entre la tradición y el arte contemporáneo. El jardín japonés». Anales de Historia del Arte 12 (2002): 251. 


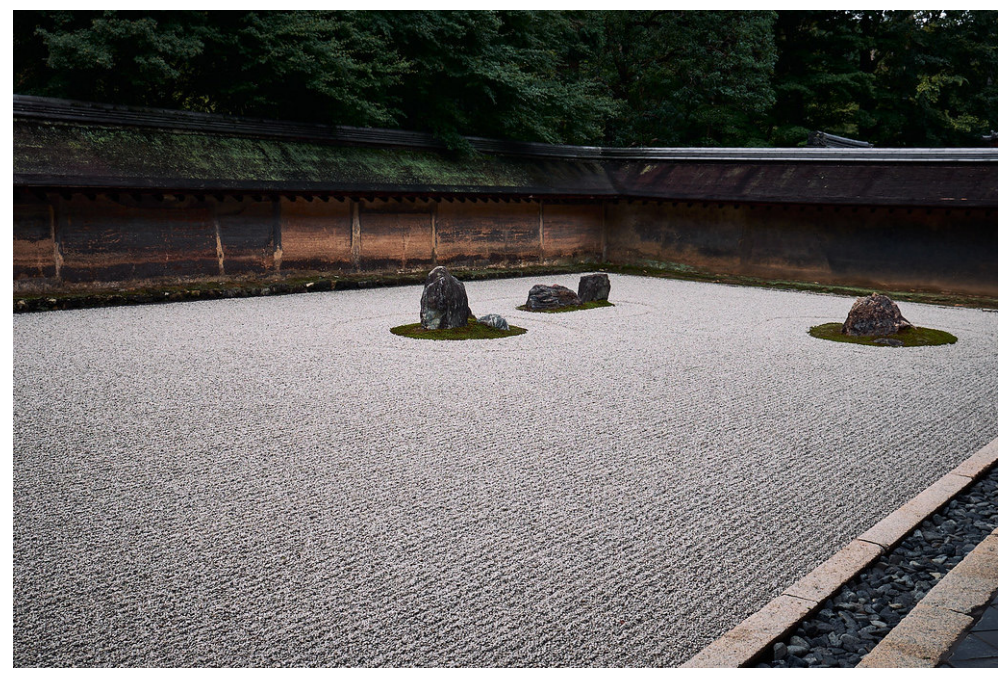

Imagen 1. Vista general del jardín de Ryōan-ji en Tokio ${ }^{10}$

El jardín japonés de Ryōan-ji está en la base de las pinturas de vacío de Joan Miró, en las cuales «sus inmensos azules donde las manchas armoniosamente distribuidas y los rastros de su pincel, son asimilados por el mismo espíritu que guía las creaciones japonesas ${ }^{11}$. También impregna las obras literarias de autores como Yukio Mishima (1925-1970) y Kobo Abe (1924-1993) e incluso de cineastas como Peter Greenaway (1942).

Muchos otros como los arquitectos Frank Lloyd Wright o Walter Gropius, poetas como Octavio Paz, escultores como Isamu Noguchi, o filósofos como Roland Barthes, han visitado este paradigma de jardín seco [Ryōan-ji], que siendo un jardín habla directamente a todos, porque [...] utiliza un lenguaje formal y unos planteamientos muy próximos a las necesidades de nuestro tiempo.

Rocas que se acercan a las esculturas invitándonos a la introspección, a proyectarnos sobre ellas, a reflexionar. Formas abstractas que buscan la unidad con la mirada del espectador. Desarrollos espaciales que podríamos confundir con las instalaciones de artistas contemporáneos [...].

Un abandono del soporte tradicional, un salto a la tridimensionalidad del espacio más allá de la escultura, un desarrollo temporal, una revalorización de otro tipo de materiales, la inclusión de la naturaleza en el ámbito artístico... Éstas son algunas de las afinidades por las que hoy [...] el jardín japonés, y en especial el jardín seco sigue estando en la avant-garde. ${ }^{12}$

10 Ángel de los Ríos. «Ryōan-ji». Flicker.com. 13 de octubre de 2019. https://www. Alickr.com/photos/ diocrio/49477285897.

${ }^{11}$ Gras Balaguer, El jardín japonés..., 489.

${ }^{12}$ Gras Balaguer, El jardín japonés..., 494. 
En música, la presencia del jardín ha sido especialmente significativa desde el impresionismo, corriente en la que los compositores se inspiraron en la naturaleza para "plasmarla en una creación musical $\gg^{13}$. A este respecto, Aracil ofrece una exhaustiva lista de obras inspiradas en jardines, entre las cuales se encuentran Juegos de agua (1901) de Maurice Ravel (1875-1937), Jardines bajo la lluvia (1903) de Claude Debussy (1862-1918) o Noche en los jardines de España de Manuel de Falla ${ }^{14}$. Esta inclinación continuó en el siglo xx. Baste mencionar para ello composiciones de estéticas muy diferentes como El libro de los Jardines Colgantes op. 15 (1908-1909) de Arnold Schönberg (1874-1951), In a Summer Garden (1908) de Frederick Delius (1862-1934) o Giardino religioso (1972) de Bruno Maderna (1920-1973).

Pero el jardín japonés, como se comenta más arriba, no cautivará a los compositores hasta la década de los setenta y ya «poco tiene que ver este auge con una moda "exótica". [...] El jardín japonés atrae ante todo por su carácter de "composición". Los músicos quedan cautivados por la disposición armónica de sus elementos, en vilo entre naturalismo y abstracción ${ }^{15}$. Además, el carácter simbólico del jardín japonés casa a la perfección con la idea contemporánea de obra abierta en «donde el artista deja abierta la obra a la interpretación del espectador [...] para invitarle a acercarse a la obra con libertad y sin ningún tipo de condicionamiento» ${ }^{16}$. Son estos aspectos, junto a otros como la asimetría, el vacío o la dualidad que serán ilustrados más adelante, los que seducen a compositores occidentales y orientales como John Cage o Toru Takemitsu (1930-1996) respectivamente.

El vacío es un elemento esencial en la música de John Cage (su pieza de silencio 4’33”' donde invita al oyente a tomar conciencia de los sonidos a su alrededor es paradigmática), dentro de la influencia que el zen ejerció en su obra a raíz de sus estudios con el maestro Suzuki Daisetsu (18701966). El jardín japonés de Ryōan-ji le inspirará la composición de varias piezas solísticas reunidas bajo el título de Ryōan-ji para oboe, voz, flauta, contrabajo y trombón. En esta obra Cage «consiguió hacer una transposición sonora del jardín. [...] Buscó indirectamente apropiarse de la estructura de los elementos físicos y de los atributos del jardín para utilizarla en su composición musical» ${ }^{17}$.

El jardín es intrínseco a la obra de Toru Takemitsu. Está en la base de numerosas piezas para distintas formaciones, desde In an Autumn Garden (1973) para orquesta gagaku y Garden Rain (1974) para grupo de metales hasta A Flock descends into the Pentagonal Garden (1977) o Spiritual Garden (1994), ambas para orquesta.

${ }^{13}$ Aracil, Música y..., 127.

${ }^{14}$ Aracil, Música y..., 128.

${ }^{15}$ Aracil, Música y..., 196.

${ }^{16}$ Gras Balaguer, El jardín japonés..., 484.

${ }^{17}$ Aracil, Música y..., 488. 
Takemitsu invita al oyente a un viaje por sus jardines sonoros, incidiendo en la ambigüedad de sus manifestaciones sonoras [...]. El jardín es un lugar de resonancias y consonancias espirituales, al que se accede por un proceso de empatía que desafía la precisión analítica. ${ }^{18}$

Es en este entorno donde se sitúa la partitura Six Japanese Gardens de Kaija Saariaho, precisamente dedicada al propio Toru Takemitsu, aunque no es la única pieza de la autora inspirada en jardines, sino que en tres obras anteriores ya había explorado los jardines de nenúfares de Monet: Jardin Secret I (1985), Jardin Secret II (1986) y Nymphea (Jardin Secret III) de 1987.

La investigación parte pues de la siguiente pregunta: ¿Cómo se materializa el concepto de jardín japonés, sus principios y elementos en la obra Six Japanese Gardens de la compositora Kaija Saariaho? Vinculada a esta, se proponen como objetivos identificar los fundamentos estéticos y simbólicos del jardín japonés empleados en la composición de la pieza musical, basándose en referentes en la materia como Cirlot $^{19}$ y Chevalier ${ }^{20}$, así como indagar en cómo intervienen los principios artísticos tradicionales japoneses en la aplicación de las técnicas de composición musical contemporáneas occidentales en la obra de Saariaho.

Para llevar a cabo estos objetivos se ha recurrido a una metodología eminentemente cualitativa ya que no corresponde un análisis estadístico o cuantificación de variables a la investigación planteada, sino que se orienta «al estudio "interpretativo" de los significados [...] desde un punto de vista más reflexivo y holístico de la realidad» ${ }^{21}$. La investigación busca entender la aplicación de los principios del jardín japonés a la música de Saariaho a través de una interpretación en la que tiene cabida la subjetividad en la reflexión. Como indican Colás y Buendía: «el objetivo de la investigación es desarrollar un cuerpo de conocimientos ideográficos que describan los casos individuales» ${ }^{22}$, esto es, el objeto de estudio de esta investigación: la obra Six Japanese Gardens.

La técnica principal que se emplea es el análisis, aplicado a la fuente primaria de la investigación: la partitura de la pieza Six Japanese Gardens publicada por Chester Music ${ }^{23}$. El análisis (tanto a nivel global como parcial de cada movimiento) se aborda desde diversos puntos de vista relevantes: estructural, matérico, tímbrico, estético y simbólico, sin descartar otras aproximaciones puntuales según sea necesario en el transcurso de la investigación.

\footnotetext{
${ }^{18}$ Aracil, Música y..., 203.

${ }^{19}$ Juan Eduardo Cirlot, Diccionario de simbolos (Barcelona: Labor, 1992).

${ }^{20}$ Jean Chevalier, dir., Diccionario de los símbolos, trad. de Juan Manuel Silvar y Arturo Rodríguez (Barcelona: Herder, 1986).

${ }^{21}$ José Quintanal y Begoña García Domingo, coords., Fundamentos Básicos de Metodología de Investigación Educativa (Madrid: editorial CCS, 2012), 76.

${ }^{22} \mathrm{M}^{\mathrm{a}}$ Pilar Colás y Leonor Buendía, Investigación Educativa (Sevilla: Alfar, 1998), 251.

${ }^{23}$ Kaija Saariaho, Six Japanese Gardens [partitura] (Londres: Chester Music LTD, 1994).
} 
- Análisis estructural: hace referencia a la configuración de la obra y sus elementos. Esto nos permite comprobar la relación entre la disposición de los jardines reales y la de los componentes musicales.

- Análisis matérico: se centra en los elementos motívicos y células musicales. Con este análisis no solo se profundiza en la propia construcción musical de la obra, sino que posibilita confrontar posibles relaciones entre el material y los elementos naturales del jardín, así como la interrelación de determinados conceptos aplicables tanto a la música como al jardín: desarrollo, recurrencia, transformación o variación.

- Análisis tímbrico: se focaliza en la elección instrumental y los recursos técnicos tímbricos empleados. Este análisis está interrelacionado con el análisis simbólico ya que favorece la dilucidación de asociaciones instrumentales simbólicas a diferentes elementos: numéricos, de la naturaleza, constitutivos de jardines particulares o colorísticos.

- Análisis simbólico y estético: estos vertebran todo el proceso analítico, ya que se orientan a la búsqueda de las formas de aplicación a la materia musical de los numerosos elementos simbólicos del jardín japonés y de sus principios estéticos principales como el vacío, la asimetría o la abstracción.

\section{I.1. Estado de la cuestión}

Todo el planteamiento ilustrado parte de una revisión bibliográfica de fuentes secundarias centrada tanto en el propio jardín japonés como en la música de Saariaho.

La bibliografía sobre jardines es extensa al abordarse desde la óptica de la arquitectura, pero cuando se centra en el jardín japonés, se reduce considerablemente. Como comenta Gras Balaguer:

Se echa de menos [...] una continuidad en los estudios, una mayor difusión de sus poéticas interiores y una sistematización de los hallazgos [...]. Y, es que, en muchas ocasiones, al referirnos a la cultura japonesa, los términos son confusos a veces para el receptor del mensaje. ${ }^{24}$

Efectivamente, los libros, artículos y monografías que abordan el jardín japonés como elemento arquitectónico son relativamente abundantes y bien documentados, como el de Fariello ${ }^{25}$ o el de Baridon ${ }^{26}$, tomando como referencia la mayoría de ellos el libro de Nitschke ${ }^{27}$. La bibliografía

${ }^{24}$ Gras Balaguer, El jardín japonés..., 280.

${ }^{25}$ Francesco Fariello, La arquitectura de los jardines. De la Antigüedad al siglo Xx, trad. de Jorge Sainz (Barcelona: Reverte, 2004).

${ }^{26}$ Michel Baridon, Los jardines. Paisajistas, jardineros, poetas, trad. de Juan Calatrava (Madrid: Abada, 2004).

${ }^{27}$ Günter Nitschke, El jardín japonés. El ángulo recto y la forma natural, trad. de Carmen Sámchez Rodríguez (Koln: Taschen, 2003). 
que aborda aspectos más estéticos o filosóficos, en cambio, es mínima. En este sentido es de destacar el libro Historia y arte del jardín japonés del arquitecto Javier $\operatorname{Vives}^{28}$, que realiza un recorrido por los principales jardines japoneses organizados históricamente, a la vez que ofrece en capítulos separados otra información adicional como sus componentes o las constantes del jardín japonés (asimetría, vacío, etc.). Pero quizá, el texto más significativo sea el coordinado por Gras Balaguer: El jardín japonés. Qué es y no es entre la espacialidad y la temporalidad del paisaje ${ }^{29}$. Esta monografía está conformada por 32 artículos de otros tantos autores organizados en cuatro grandes bloques que abarcan la estética del jardín, su simbología, sus elementos y su significado cultural. Este texto resulta una monografía de referencia imprescindible donde diferentes expertos abordan la estética y la simbología del jardín, explicándolas desde sus orígenes y señalándolas en los lugares reales. El libro hace un recorrido por las diferentes épocas, sin eludir comparaciones con jardines occidentales o el jardín persa ni la interrelación con otras artes como la literatura o la pintura, hasta llegar a la actualidad y a los artistas contemporáneos que aún continúan la tradición a través de su obra.

Si la literatura sobre el jardín japonés es breve, la documentación que aborda la relación entre el jardín y la música se reduce al libro de Aracil, Música y jardines ${ }^{30}$. El texto es fruto de la colaboración de varios autores, músicos profesionales y aficionados, cada uno de los cuales se ha encargado de un capítulo centrado en su especialidad. Así, el libro abarca la temática desde diversas perspectivas tanto musicales como estéticas y literarias, incluyendo un estudio a modo de prólogo de la pluma del compositor Alfredo Aracil (1954), editor de la obra, que realiza un breve recorrido por la presencia del jardín en el arte desde la Antigüedad hasta nuestros días. Música y jardines forma parte de las publicaciones del archivo de Manuel de Falla y, por lo tanto, gran parte del texto (casi la mitad de sus páginas) se centra en la figura del compositor gaditano; a destacar el último estudio del musicólogo Stefano Russomano (1969) centrado en el siglo xx, en el que se abordan composiciones basadas en el concepto de jardín o en jardines concretos, resaltándose su encarnación en los aspectos meramente musicales, incluyendo brevemente la obra objeto de este estudio.

En el caso de la literatura centrada en Kaija Saariaho, esta es bastante limitada. Existen algunas monografías en otros idiomas (francés, alemán e inglés) que se basan en entrevistas, como el libro de Howell de 2011 en inglés ${ }^{31}$, una recopilación de nueve artículos escritos por la compositora en los que se explican algunas obras como Nymphea (1987). También en inglés está el libro publicado en 2009 de Pirkko Moisala ${ }^{32}$ en el que se habla de la compositora pero sin centrarse en ninguna partitura. En

${ }^{28}$ Javier Vives, Historia y arte del jardín japonés (Gijón: Satori Ediciones, 2014).

${ }^{29}$ Menene Gras Balaguer, dir., El jardín japonés: qué es y qué no es entre la espacialidad y la temporalidad del paisaje (Madrid: Tecnos, 2015).

${ }^{30}$ Alfredo Aracil, ed., Música y Jardines (Granada: Archivo Manuel de Falla, 2003).

${ }^{31}$ Tim Howell, ed., Kaija Saariabo: Visions, Narratives, Dialogues (Oxford: Routledge, 2011).

${ }^{32}$ Pirkko Moisala, Kaija Saariaho (Cahmpaign: University of lllinois Press, 2009). 
francés se encuentra el libro de 1994 de Michel, Stoïanova y Pousset ${ }^{33}$, que además de una entrevista incluye un ensayo sobre las obras orquestales de Saariaho de la década de los ochenta y principios de los noventa. Por último, en alemán, el libro publicado en 1991 por Winterfeldt como editor ${ }^{34}$ se centra nuevamente en las obras orquestales de principios de la década de los noventa.

Es de mencionar que hay algunos textos que tratan expresamente la obra Six Japanese Gardens: en primer lugar, un artículo de 2004 realizado por Elizabeth R. Cohen ${ }^{35}$ para un curso de historia de la música electroacústica de la Universidad de Pennsylvania en el que la autora retrata muy brevemente sus impresiones en la escucha de la obra y aporta alguna idea sobre la posible inspiración de cada jardín. Algo más extenso es el artículo de 2017 de Jean-Louis Di Santo ${ }^{36}$ que se centra en la interculturalidad Oriente-Occidente de la obra a través de un análisis formal (a partir de una transcripción auditiva) y un análisis filosófico (a partir del estudio de temporalidades y patrones de repetición) del primer movimiento. También es destacable la tesis leída en 2011 por el Dr. Meyer «Six Japanese Gardens and Trois Rivières: Delta: An analysis of Kaija Saariaho's two major works for solo percussion and electronics» ${ }^{37}$, en la cual se aborda un análisis de la obra pero focalizado en la parte percusiva desde un punto de vista de corte técnico-instrumental.

Ya en español pueden encontrarse varios artículos sobre la compositora finlandesa así como algunas reseñas o breves trabajos, pero la única tesis publicada sobre su obra es «Nuevas perspectivas sonoras. K. Saariaho y los enfoques de creación contemporáneos. Estudio de tres obras del siglo xxI: L'amour de loin, Aile du songe y Notes on lights de la Dra. Salvadora Díaz Jerez, leída en la Universidad de La Laguna (Tenerife) en 2016 y que como indica su título se centra en dichas tres obras orquestales.

De esta forma, la literatura sobre la obra que nos ocupa, Six Japanese Gardens, es bastante reducida y no se realiza un estudio profundo entre la relación de los jardines japoneses y la misma, por lo que este trabajo podría ser precursor de una nueva línea de investigación en la obra de Kaija Saariaho.

${ }^{33}$ Pierre Michel; Ivanka Stoïanova y Damien Pousset, Kaija Saariaho (París: IRCAM, 2014).

${ }^{34}$ Susanne Winterfeldt, ed., Kaija Saariaho (Berlín: Musikfrauen, 1991).

${ }^{35}$ Elizabeth R. Cohen, «Kaija Saariaho. Six Japanese Gardens», en INART55 (Filadelfia: Universidad de Pensylvania, 2004). http://www.personal.psu.edu/meb26/INART55/pastpapers/sixjapgdns.pdf.

${ }^{36}$ Jean-Louis Di Santo, «Six Japanese gardens by K. Saariaho: eastern and western temporalities», en Proceedings of the Electroacoustic Music Studies Network Conference (EMS17) (Nagoya: 2017). http://www.ems-network.org/IMG/ pdf EMS17 DiSanto.pdf.

${ }^{37}$ Bardley Edward Meyer, «Six Japanese Gardens and Trois Rivières: Delta: An analysis of Kaija Saariaho's two major works for solo percussion and electronics» (tesis doctoral, Universidad de Kentucky, 2011), https://uknowledge.

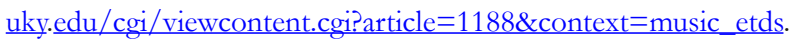




\section{Simbología DEL JARDÍN JAPONÉS}

El espíritu japonés es indisociable del amor por la naturaleza. Este sentimiento está tan arraigado que ha sido elevado a categoría estética e incluso religiosa. Escribe así Suzuki:

El amor de los japoneses a la naturaleza tiene sin duda su origen en el innato sentido estético para las cosas hermosas; pero la apreciación de lo bello es en el fondo religiosa, pues si no se es religioso no se puede detectar y gozar lo que es genuinamente hermoso. ${ }^{38}$

El amor por la naturaleza se traduce incluso en el furyu, un sentimiento de goce desinteresado de lo natural, una categoría estética tradicional japonesa definida por Gras Balaguer como «un arte del goce estético asociado al entorno paisajístico, sobre todo al jardín, entendido este como un lugar utópico donde el ser humano se encuentra con lo sublime, y satisface sus deseos» ${ }^{39}$.

Por ello no resulta extraño que «el patrimonio cultural y arquitectónico [japonés] aparecen siempre ligados al paisaje y participando de él» ${ }^{40}$. Baste mencionar como ejemplo el templo budista Horyuji o el santuario sintoísta de Itsukushima.

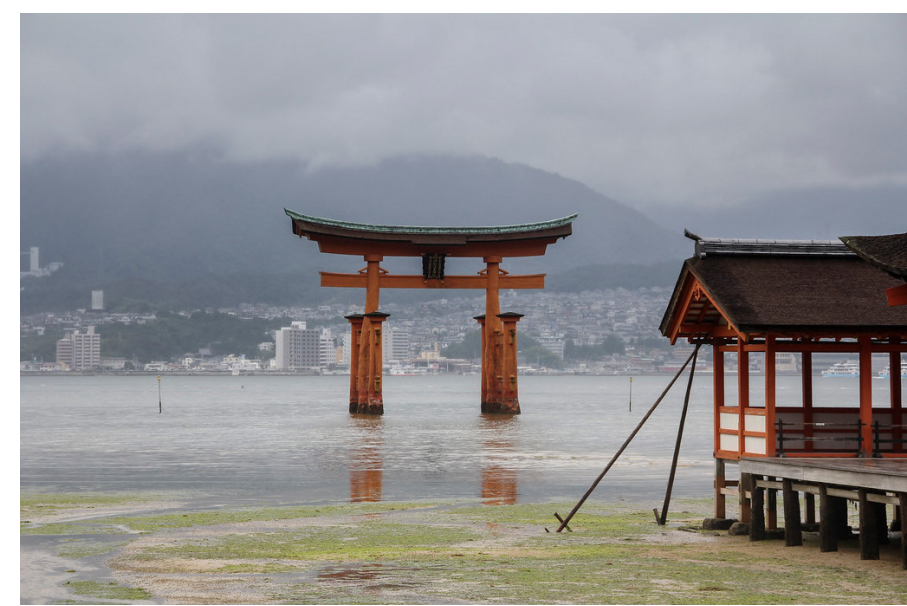

Imagen 2. Torii (arco tradicional que sirve de entrada al recinto sagrado) del santuario sintoísta de Itsukushima ${ }^{41}$

${ }^{38}$ Daisetz Suzuki, El zen y la cultura japonesa, trad. de María Tabuyo y Agustín López (Barcelona: Paidós, 1996), 242.

${ }^{39}$ Gras Balaguer, El jardín japonés..., 151.

${ }^{40}$ M. ${ }^{a}$ Dolores Palacios, «Patrimonio y paisaje en Japón», Axa. Una revista de Arte y Arquitectura 7 (2015): 8.

${ }^{41}$ Alexia Montavion. «Torii, Itsukushima-jinja». Flickr.com. 20 de julio de 2015. https://www.flickr.com/ photos/alan736/28086495464. 
Este profundo vínculo con la naturaleza queda patente en el arte del jardín japonés, concebido siempre como una naturaleza recreada; como indica Cabañas:

El jardín japonés es [...] un jardín simbólico donde los elementos presentes nos llevan a una realidad distinta, evocando el paraíso, o lo que de eterno hay en el continuo devenir. El jardín japonés es un microcosmos [...]. Si según la filosofía china un árbol puede representar el bosque, un pequeño espacio también puede contener el universo. ${ }^{42}$

Algunos jardines japoneses se basan en escenarios reales o paisajes de cuentos y poemas, pero nunca son una mera copia, sino que buscan «crear una visión abstracta o simbólica por medio de un escenario natural» ${ }^{43}$. Es aquí donde entra en juego el concepto de mitate, esto es, metáfora ${ }^{44}$. Al igual que otras manifestaciones artísticas japonesas como el baik $u^{45}$ o el kabuki $i^{46}$, el jardín japonés se apoya en reproducir una obra de arte a partir de la sugerencia de un elemento real.

El jardín japonés no es un mero ejercicio paisajista para el esparcimiento. Gras Balaguer lo define así:

Más que una técnica de jardinería, en el jardín japonés lo que domina es una filosofía y una estética que se aplica a la naturaleza y una visión del cosmos que deriva del budismo y el sintoísmo. Normas e instrucciones sobre los elementos que forman parte del jardín y su disposición se articulan con la filosofía y la religión [...]. Esto no es un jardín, porque todas sus formas son efímeras, son y no son, como se repite incesantemente desde los orígenes de la literatura japonesa hasta hoy. ${ }^{47}$

Esta concepción de la representación simbólica de la naturaleza se enraíza profundamente con la creencia sintoísta tradicional de que «todo en la naturaleza es sagrado, desde los árboles y las plantas hasta los objetos inanimados como las rocas o el agua» ${ }^{48}$. El sintoísmo se basa en la creencia

\footnotetext{
${ }^{42}$ Cabañas, «Un puente ...», 241.

${ }^{43}$ Eriko Terao, «El jardín japonés como microcosmos. Lo invisible en el jardín japonés», Galicia y Japón: del sol naciente al sol poniente. IX Encuentros internacionales de filosofía en el Camino de Santiago (2009): 235.

${ }^{44}$ Terao, «El jardín japonés...», 234.

${ }^{45} \mathrm{El}$ haiku es un género poético originario de Japón; cada poema consta de tres versos sin rima con 5,7 y 5 sílabas respectivamente.

${ }^{46} \mathrm{El} \mathrm{kabuki}$ es un género teatral japonés tradicional en el que se presenta un drama estilizado y que se caracteriza por el peculiar maquillaje de los actores, la inclusión de música con instrumentos tradicionales, unos estilos de actuación ritualizados y por ser interpretado en exclusiva por hombres (incluso los papeles femeninos). Puede verse una breve explicación en el siguiente vídeo: UNESCO en español, «El teatro Kabiku», vídeo de YouTube, 04:23, publicado el 29 de septiembre de 2009, https://www.youtube.com/watch?v=G71-YMHYbQI.

${ }^{47}$ Gras Balaguer, El jardín japonés..., 21.

${ }^{48}$ Gras Balaguer, El jardín japonés..., 505.
} 
en los kami, divinidades que se encarnan en elementos naturales y que pueden proteger o perjudicar las actividades humanas ${ }^{49}$.

Hay que tener en cuenta para tratar de entender el sistema religioso japonés que este es de carácter sincrético, ya que aúna el sintoísmo ${ }^{50}$ tradicional con otras creencias foráneas que fueron introducidas en el archipiélago en distintos momentos históricos: el budismo, el taoísmo ${ }^{51}$ y posteriormente incluso el cristianismo ${ }^{52}$. Para la comprensión del jardín japonés, son de especial relevancia el taoísmo y el budismo (concretamente el budismo zen), que fueron importados desde China, al igual que el propio jardín.

Según Suzuki: «el zen es uno de los resultados del contacto de la mentalidad china con el pensamiento indio, introducido en China en el siglo I d. C. por medio de las enseñanzas budistas» ${ }^{53}$. Además, también absorbió influencias del taoísmo antes de penetrar en Japón entre los siglos XIII y XIV, donde alcanzó un gran desarrollo hasta el punto de que «el zen [...] ha impregnado profundamente todos los aspectos de la vida cultural del pueblo [japonés] $\rangle^{54}$. Esto es comprensible teniendo en cuenta que el budismo zen no se contradice con los aspectos del sintoísmo, religión que se basa únicamente en el culto a la naturaleza. Con respecto a esta, el zen plantea un acercamiento respetuoso, "propone respetar y amar la naturaleza [...]; el zen reconoce que nuestra naturaleza es una con la naturaleza objetiva $[. .$.$] en el sentido de que la naturaleza vive en nosotros y nosotros vivimos en la naturaleza» { }^{55}$.

El jardín japonés es indisociable del pensamiento zen, ya que su propio carácter simbólico se arraiga en el mismo. Como indica Okakura:

El Zen aportó al pensamiento oriental la noción igualitaria establecida entre los asuntos temporales y espirituales. En las relaciones superiores de las cosas no existe diferencia entre lo sencillo y lo complejo, lo grande o lo pequeño: un átomo posee las mismas posibilidades que el Universo. ${ }^{56}$

A grandes rasgos, el zen se fundamenta en la idea de la meditación (generalmente en la postura sentada con las piernas cruzadas) como camino para lograr la iluminación o satori. Para ello se basa en

${ }^{49}$ Gras Balaguer, El jardín japonés..., 505.

${ }^{50} \mathrm{El}$ sintoísmo es una religión tradicional animista en la que se diviniza las fuerzas y elementos de la naturaleza.

${ }^{51}$ El taoísmo es una corriente filosófica de origen chino fundada por Lao-Tsé (siglo vi a. C.) y que se basa en el tao, un concepto abstracto de difícil definición y que deviene en un camino o sendero que permite vivir en armonía con el Universo.

${ }^{52}$ Suzuki, El zen..., 13.

${ }^{53}$ Suzuki, El zen..., 13.

${ }^{54}$ Suzuki, El zen..., 24.

${ }^{55}$ Suzuki, El zen..., 234.

${ }^{56}$ Kakuzo Okakura, El libro del té. La ceremonia del té japonesa (Cha no Yu), trad. de José Javier Fuente del Pilar (Madrid: Miraguano, 2012), 59. 
ciertos principios fundamentales como la sencillez, la dualidad, la contemplación, la abstracción y el vacío; estos principios también se aplican al jardín japonés.

\section{II.1. Principios fundamentales comunes al zen y al jardín japonés}

\section{II.1.1. La contemplación y meditación}

El zen indica que la iluminación no puede alcanzarse sin la concentración adecuada, denominada sammai, que debe dirigirse hacia un solo punto ${ }^{57}$. El jardín zen japonés sirve como vehículo para este estado mental, «tiene por objeto la contemplación y la meditación, [lo que] obedece a una filosofía según la cual el hombre es consciente de su pertenencia a la naturaleza, en la que intenta sumergirse espiritualmentes ${ }^{58}$.

Por esta razón, «los jardines budistas se interpretaban como la plasmación tridimensional de una pintura paisajística $\rangle^{59}$. Así, cobra gran importancia la idea del encuadre en aquellos jardines que no están concebidos para el paseo, especialmente en los karesansui (jardín seco) que estaban diseñados para verse desde el interior del edificio, buscándose el meigakure, «mejor ángulo de observación del jardín» ${ }^{60}$.

De esta forma, el jardín adquiere un carácter pictórico que exterioriza los valores plásticos del zen y que consiste en:

Lograr, mediante un uso económico de los medios, el efecto de no acabamiento, en aplicar los principios [...] de la irregularidad, con la convicción de que con la suma de todos los factores se disponían las bases operativas del camino conducente de la belleza imperfecta a la belleza infinita. ${ }^{61}$

\section{II.1.2. La sencillez y la abstracción}

Uno de los principios básicos del zen es la sencillez, la eliminación de todo lo innecesario para alcanzar la iluminación; como indica Suzuki: «el zen aspira [...] a despojarse de todas las envolturas artificiales que ha inventado la humanidad ${ }^{62}$. Esto se traduce en el wabi ${ }^{63}$, que impregna el jardín

${ }^{57}$ Suzuki, El zen..., 14.

${ }^{58}$ Gras Balaguer, El jardín japonés..., 35.

${ }^{59}$ Vives, Historia y arte..., 213.

${ }^{60}$ Gras Balaguer, El jardín japonés..., 41.

${ }^{61}$ Gras Balaguer, El jardín japonés..., 532.

${ }^{62}$ Suzuki, El zen..., 182.

${ }^{63} \mathrm{El}$ wabi es una categoría estética que hace referencia a la pobreza entendida como austeridad. En un plano espiritual es la no dependencia de las cosas terrenales, estando satisfecho con lo que se tiene y apreciando el valor de 
japonés y otras artes como la ceremonia del té, y que hace referencia a un estado de pobreza o soledad ${ }^{64}$; Gras Balaguer lo define como «el desprendimiento del mundo material, para alcanzar el ideal zen en el camino de la iluminación y conocer la verdad última» ${ }^{65}$. A nivel artístico, es una suerte de austeridad en los materiales o trazos lo que lleva en el jardín japonés a la economía, a veces extrema, de medios denominada kanso ${ }^{66}$, como en Ryōan-ji, jardín de grava en el que solo pueden verse quince piedras en una disposición determinada.

Unido a la sencillez, está la cuestión del rechazo del zen a toda conceptualización, ya que «los conceptos son útiles para definir la verdad de las cosas mas no para conocerlas personalmente» ${ }^{67}$. Esto en el campo artístico deriva en la abstracción y en el jardín japonés en el yügen, la sugerencia, que «vale más que la demostración porque potencia la imaginación» ${ }^{68}$ o según la definición de Nitschke: «una simplicidad elegante y profunda que está acompañada de un simbolismo múltiple» ${ }^{69}$.

Estas ideas se ponen especialmente de manifiesto en los jardines karesansui (secos), que no cuentan ni con vegetación ni agua. En palabras de Gras Balaguer:

Estos «desolados» jardines nos introducen en los secretos interiores de la Naturaleza y de la existencia humana. Su escenario nos eleva a composiciones abstractas de volúmenes, espacios, texturas y ritmos. Las rocas nos despiertan a significados simbólicos de mayor profundidad. ${ }^{70}$

\section{II.1.3. La dualidad y la asimetría}

Otro de los aspectos indisolubles del zen y del arte japonés es la dualidad. El zen indica que «la verdad no puede aprehenderse sino por la unión de los contrarios» ${ }^{71}$. Esta dualidad se revela en el Yin y el Yang, la unión de los opuestos que se complementan pero que aun así conforman una unidad totalitaria ya que «uno de ellos no puede existir sin el otro y $[\ldots]$ se genera una dependencia mutua» ${ }^{72}$. Aplicado al jardín japonés: «el hombre y la naturaleza son dos elementos complementarios, de

aquello que está por encima del tiempo y la posición social. En arte se traduce en una economía de medios, en la idea de que puede llegarse a una alta cota de expresión a través de un número mínimo de elementos.

${ }^{64}$ Suzuki, El zen..., 194.

${ }^{65}$ Gras Balaguer, El jardín japonés..., 31.

${ }^{66}$ Gras Balaguer, El jardín japonés..., 41.

${ }^{67}$ Suzuki, El zen..., 148.

${ }^{68}$ Gras Balaguer, El jardin japonés..., 41.

${ }^{69}$ Nitschke, El jardin japonés..., 104.

${ }^{70}$ Gras Balaguer, El jardín japonés..., 133.

${ }^{71}$ Okakura, El libro del té..., 57.

${ }^{72}$ Gras Balaguer, El jardín japonés..., 342. 
manera que cada uno toma su valor e identidad del otro y donde la ausencia de uno causa defecto en el otro» ${ }^{73}$.

Esta dicotomía se manifiesta en el jardín en tres aspectos: la relación interior/exterior, la asimetría y la unión entre lo temporal (o terrenal) y lo espiritual. En el jardín se busca la conciliación de dos formas de belleza: la perfecta y la imperfecta, la geométrica y la asimétrica; esto se revela tanto en la relación arquitectónica exterior-interior como en la «simbiosis figurativa del ángulo recto y la forma natural» ${ }^{74}$.

La unión entre arquitectura y jardinería en Japón es indisoluble y así lo explica Fahr-Becker:

La versión japonesa de «hogar» es katei, palabra que se escribe con los signos ortográficos correspondientes a «casa» (ka) y «jardín» (tę), lo cual no deja de ser una significativa indicación de la relación indisoluble que existe entre ambos en la mentalidad japonesa. ${ }^{75}$

Esta particular visión de la relación exterior-interior conlleva también la dicotomía entre la aparente naturalidad del jardín y las líneas rectas artificiales de los edificios arquitectónicos; aunque en ambos aspectos se busca la asimetría. En el caso del jardín japonés, la asimetría se empleaba para «obtener un conjunto equilibrado» ${ }^{76}$ debido a la irregularidad natural de las piedras usadas. Esto llevó al uso simbólico de conjuntos impares, generalmente de tres elementos.

El equilibrio dinámico de los números impares, principio latente de la tríada, resulta omnipresente en la cultura japonesa. La tensa configuración de tres elementos, uno grande, uno pequeño y uno mediano, no solo es el principio compositivo fundamental de la jardinería japonesa, sino también del teatro noh y el arte de componer flores, ikebana. ${ }^{77}$

Pero la asimetría no responde solo a una finalidad práctica, sino que cumple una función estética, tal y como lo describe Gras Balaguer: «el jardín japonés alcanzó su expresión con la ausencia de ejes de simetría o con estructuras incompletas que, por medio de la imaginación el observador podía completar $\rangle^{78}$. Esta última afirmación se imbrica directamente con la idea de la ambivalencia, el hecho de que el jardín japonés es una obra de arte que no está completa sin la mirada del espectador, y que esta será cambiante según quien mire.

\footnotetext{
${ }^{73}$ Gras Balaguer, El jardín japonés..., 342.

${ }^{74}$ Cabañas, «Un puente...», 248.

${ }^{75}$ Gabriele Fahr-Becker, Arte asiático, trad. de Ambrosio Berasain Villanueva y otros (Potsdam: Ullman, 2011), 633.

${ }^{76}$ Vives, Historia y arte..., 216.

${ }^{77}$ Nitschke, El jardín japonés..., 25.

${ }^{78}$ Gras Balaguer, El jardín japonés..., 452.
} 
La última manifestación de la dualidad se encuentra en la relación entre lo terrenal y lo espiritual. Ambos principios coexisten en el jardín japonés y es una aportación del zen que sustenta la idea ya comentada del jardín como una representación simbólica:

El Zen aportó al pensamiento oriental la noción igualitaria establecida entre los asuntos temporales y espirituales. En las relaciones superiores de las cosas no existe diferencia entre lo sencillo y lo complejo, lo grande o lo pequeño: un átomo posee las mismas posibilidades que el Universo.

Quien busca la perfección debe hallar en su propia vida el reflejo de la luz interior. ${ }^{79}$

\section{II.1.4. El vacio}

El zen se basa en la idea de la meditación como camino para lograr la iluminación o satori; este camino permite alcanzar el estado de vacío o mu. La «realización de paisajes reducidos a formas-esencia podía llevar a elevar el nivel de abstracción que conviene a la meditación sobre la propia nada» ${ }^{80}$. Este vacío se expresa en los jardines «donde a través de la contemplación de la nada se llega a intuir la inmensidad existente que se sucede tras la naturaleza» ${ }^{81}$.

El vacío es un principio que en el jardín se expresa en plena relación con la idea de la dualidad a través del ma, un «espacio que invoca la dualidad entre vacío y lleno y la interacción o el equilibrio que se genera entre estos opuestos» ${ }^{82}$. Más concretamente, el jardín japonés «es un espacio de representación del cosmos [...] equivalente a un gran vacío -el mar- que se puebla de islas» ${ }^{83}$. Esto se enraíza directamente con el budismo y la «imagen de la montaña cósmica Shumi-sen (la montaña Sumi) en el centro del mundo [...]. Esta cosmología [...] se refleja en el jardín japonés $»^{84}$.

El vacío se interrelaciona con la ambivalencia y la abstracción ya que «alcanza máxima expresión en la búsqueda de la sugerencia. El artista, que no lo dice todo en su obra, permite al espectador integrar su idea [...]. Percibimos un vacío que podemos llenar con nuestros sentimientos

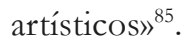

\footnotetext{
${ }^{79}$ Okakura, El libro del té..., 59.

${ }^{80}$ Baridon, Los jardines..., 92.

${ }^{81}$ Gras Balaguer, El jardín japonés..., 430.

${ }^{82}$ Gras Balaguer, El jardin japonés..., 41.

${ }^{83}$ Gras Balaguer, El jardin japonés..., 39.

${ }^{84}$ Nitschke, El jardín japonés..., 22.

${ }^{85}$ Okakura, El libro del té..., 54.
} 


\section{KAIJA SAARIAHO Y SU OBRA: SIX JAPANESE GARDENS}

Kaija Saariaho ${ }^{86}$ es una compositora cuya música desafía la clasificación: «el sonido de Saariaho es único y se gobierna por leyes que son de su propio cuño» ${ }^{87}$. No hay que olvidar que la segunda mitad del siglo xx refleja «una multiplicidad [...] extrema de métodos y enfoques. Desplazando a las ideas de una corriente dominante» ${ }^{88}$; ello dará lugar a un resurgimiento de las personalidades individuales, una redefinición del objeto sonoro y a un cuestionamiento de la tradición «desafiando a la vez los límites establecidos durante tanto tiempo entre las distintas tradiciones musicales, entre la música y otras formas culturales, y entre los compositores y sus públicos» ${ }^{89}$.

Kaija Saariaho nació en Helsinki (Finlandia) en 1952 y se inició en la música a temprana edad estudiando violín y piano, aunque su carrera artística comenzó en las artes visuales al matricularse de Bellas Artes en la Universidad de Arte y Diseño de Helsinki en $1972^{90}$. Quizá de ahí provenga su gusto por las imágenes poéticas reflejadas en su música, como en «Lichthogen (Arco de Luz) [donde el oyente] deberá imaginar los arcos luminosos de la luz nórdica; una de las lunas de Júpiter en $I o ;[\ldots]$ o la contemplación del firmamento estrellado y el microcosmos de una flor que propone Pétals» $\rangle^{11}$.

La música finlandesa de la segunda mitad del siglo xx estaba marcada por el nacionalismo de Jean Sibelius (1865-1957), creador considerado como figura de referencia para los compositores del país. Saariaho no se sustraerá a esta influencia en sus primeros años, pero se verá matizada por la del compositor post-serial Paavo Heininen (1938), con quien estudiará formalmente composición entre 1976 y 1981 en la Academia Sibelius ${ }^{92}$. Esta será una época importante en la formación de la compositora, ya que fundará junto a otros artistas como Magnus Lindberg (1958) el grupo experimental Korvat Auki (Oídos Abiertos).

Posteriormente se trasladará a Friburgo, donde estudiará con Brian Ferneyhough (1943), y finalmente recalará en 1982 en el IRCAM de París, ciudad en la que reside en la actualidad. Este periplo la llevará al abandono de las técnicas contrapuntísticas seriales y volverá su música hacia el espectralismo de compositores como Gerard Grisey (1946-1998) o Tristan Murail (1947), cuya influencia es palpable

${ }^{86}$ Recomendamos la visita a la web de la compositora, donde se explicitan obras, grabaciones, conciertos y otras informaciones de interés: «Kaija Saariaho», Paul Sacher Foundation, acceso el 5 de febrero de 2021, https:// saariaho.org/.

${ }^{87}$ Carlos Barreiro, «La compositora filandesa Kaija Saariaho. Música que llega del frío», Artes, La Revista 7, n. ${ }^{\circ}$ 13 (2007): 45.

${ }^{88}$ Joseph Auner, La música en los siglos XX y XXI, trad. de Juan González-Castelao (Madrid: Akal, 2017), 279.

${ }^{89}$ Auner, La música ..., 80.

${ }^{90}$ Alicia Díaz de la Fuente, «El sonido de Kaija Saariaho», Música. Revista del Real Conservatorio de Música de Madrid 23 (2016): 153.

${ }^{91}$ Barreiro, «La compositora filandesa ...», 45.

${ }^{92}$ Moisala, Kaija Saariaho, 4. 
en las piezas de Saariaho a partir de esta fecha, en la que aumenta su preocupación por el timbre: «su concepción del sonido se volverá cada vez más refinada y personal y el ordenador una valiosa e insustituible herramienta de trabajo, necesaria pero no determinante [...]. De este modo, sus obras denotan un cuidado exquisito del color instrumental» ${ }^{93}$.

Esta importancia concedida al timbre impregnará su concepción compositiva hasta la actualidad; de hecho, de acuerdo con Díaz de la Fuente, «emplea el timbre para crear la forma musical de un modo tal que el timbre ocuparía el lugar de la armonía como elemento progresivo de la música» ${ }^{94}$. Además, emplea elementos como «el timbre, la armonía, el ritmo o el registro, según un juego de oposiciones que permiten crear texturas diversas y ricas» ${ }^{9}$.

Esta idea compositiva es la que subyace en la obra objeto de estudio de este trabajo: Six Japanese Gardens para percusión y electrónica en vivo ${ }^{96}$. Esta pieza, como indica la propia Saariaho, «es una colección de impresiones de los jardines que vi en Kioto durante mi estancia en Japón en el verano de 1993 y mis reflexiones sobre el ritmo en esa época ${ }^{97}$. La obra no emplea una forma preestablecida, sino que la manipulación del material sonoro (que en numerosas ocasiones se basa en un juego de opuestos o de dualidad como se verá), ya sea en su faceta tímbrica, rítmica u otra, será quien la determine. Además, la obra refleja esa manipulación en numerosas ocasiones como una transformación textural con una clara referencia visual poética de los jardines japoneses que la inspiran y un empleo de la electrónica que, si bien es significativo, no resulta imprescindible para conocer y comprender el proceso de la obra.

La obra consta de seis piezas, cada una de las cuales hace referencia a un jardín concreto. Cada pieza emplea una combinación diferente de instrumentos tomados del conjunto general y que se especifican en la siguiente tabla.

${ }^{93}$ Díaz de la Fuente, «El sonido...», 155.

${ }^{94}$ Díaz de la Fuente, «El sonido...», 158.

${ }^{95}$ Díaz de la Fuente, «El sonido...», 158.

${ }^{96}$ La ficha de la obra puede consultarse en la web de la compositora: https://saariaho.org/works/six-japanesegardens/.

${ }^{97}$ is a collection of impressions of the gardens I saw in Kyoto during my stay in Japan in the summer of 1993 and my reflections on rbythm at that time.

Kaija Saariaho, Six Japanese Gardens [partitura] (Londres: Chester Music LTD, 1994), notas a la partitura, s. p. 
Tabla 1. Instrumentación general y combinaciones empleadas en cada pieza de la obra

Triángulo

Placa de metal

Caja china

Tambor de hendidura

Piedras

Plato suspendido pequeño

Tres crótalos (no afinados) suspendidos

Platos zen

2 gongs

Crótalos afinados (1 octava)

Tambor chino

Pandereta

3 timbales

Tamtam

Electrónica

$\begin{array}{cccccc}\text { Pieza I } & \text { Pieza II } & \text { Pieza III } & \text { Pieza IV } & \text { Pieza V } & \text { Pieza VI } \\ \mathrm{X} & & & & \mathrm{X} & \mathrm{X} \\ & \mathrm{X} & & & & \mathrm{X} \\ \mathrm{X} & & & & & \mathrm{X} \\ \mathrm{X} & & & \mathrm{X} & & \mathrm{X} \\ & & & & \\ \mathrm{X} & & \mathrm{X} & & \mathrm{X}\end{array}$

$\begin{array}{cccccc}\text { Pieza I } & \text { Pieza II } & \text { Pieza III } & \text { Pieza IV } & \text { Pieza V } & \text { Pieza VI } \\ \text { X } & & \mathrm{X} & \mathrm{X} & & \mathrm{X} \\ \mathrm{X} & & & & \mathrm{X} & \mathrm{X} \\ & & & & & \mathrm{X} \\ \mathrm{X} & & & & \mathrm{X} & \mathrm{X} \\ \mathrm{X} & \mathrm{X} & \mathrm{X} & & & \mathrm{X} \\ & & \mathrm{X} & \mathrm{X} & & \\ \mathrm{X} & \mathrm{X} & \mathrm{X} & \mathrm{X} & \mathrm{X} & \mathrm{X}\end{array}$

Es preciso aclarar que en dos piezas algunos instrumentos no se especifican, sino que se deja su elección a criterio del intérprete: en la pieza III se pide madera, parche y piedra (altura indeterminada) y en la pieza $V$ se pide madera, metal y piedra.

El equipo requerido para la parte de electrónica en vivo es el siguiente:

- Mackintosh con Digidesign Soundtools o ProTools II.

- Interface Midi.

- Yamaha SPX1000.

- Lexicon LXP15.

- Pedal de sustain.

- Micrófonos direccionales, el número depende del espacio elegido para la interpretación.

- PA mixer.

- Amplificación estéreo de buena calidad.

Para el presente texto, se tendrá en cuenta no solo la partitura original de la obra sino también la grabación de la misma realizada por el percusionista Thierry Miroglio y publicada en 2002 por INA-GRA ${ }^{98}$.

${ }^{98}$ Kaija Saariaho, Kaija Saariaho. Oeuvres dédiées. Thierry Miroglio, percusión. INA-GRM, 2002, CD. 


\section{III.1. Análisis de las piezas individuales ${ }^{99}$}

\section{III.1.1. Tenju-an garden of Nanzen-ji Temple}

Esta pieza inaugural de Six Japanese Gardens se inspira en uno de los jardines del monasterio budista zen de Nanzen-ji, uno de los cinco templos principales situados en Kioto ${ }^{100}$. Este jardín se construye en la era Edo (1603-1868) ${ }^{101}$, época en la que proliferarán los jardines en los patios de los edificios monacales, especialmente anexos a la residencia del prior, como es este caso; estamos pues, ante un jardín karesansui o seco, aunque no exento de elementos verdes como el musgo y los árboles, cuya finalidad es focalizar la meditación. El jardín es atribuido a uno de los considerados mayores maestros jardineros en la historia del jardín japonés y renovador del estilo: Kobori Enshū (1579-1647), y resulta, en comparación con otros jardines del mismo estilo, más natural, menos severo ${ }^{102}$.

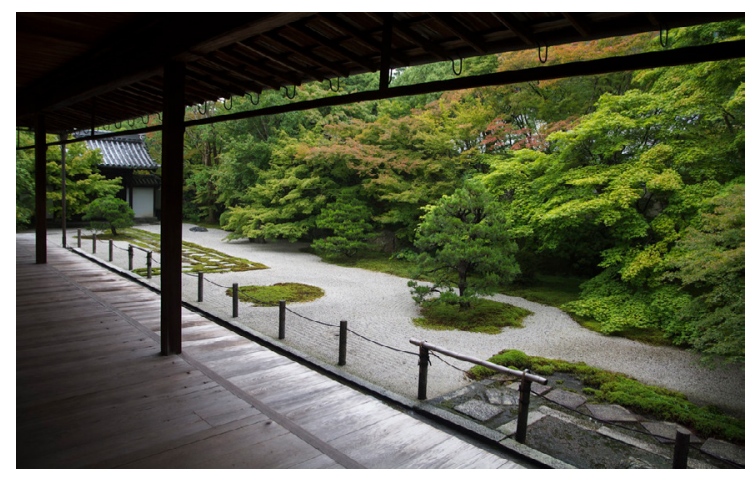

Imagen 3. Vista de Tenju-an desde la residencia del prior ${ }^{103}$

${ }^{99}$ Puede escucharse la obra completa de forma gratuita en YouTube interpretada por Florent Jodelet en Wellesz Opus, «Kaija Saariaho: Six Japanese Gardens (1994)», vídeo de YouTube, 18:53, publicado el 7 de febrero de 2015, https:// www.youtube.com/watch?v=bQLA4cUv1IQ. También por Shane Jones en Shane Jones, «Six Japanese Gardens - Kaija Saariaho», vídeo de YouTube, 15:58, publicado el 26 de enero de 2017, https://www.youtube.com/watch?v=x7t-n3EDqpM.

${ }^{100}$ Vives, Historia y arte..., 136. Puede encontrarse información e imágenes de este templo y su jardín en: «Japan-Guide», Stefan Schauwecker, acceso el 7 de febrero de 2021, https://www.japan-guide.com/e/e3905.html.

${ }^{101}$ La historia de Japón de subdivide hasta 1868 en periodos en base a determinados acontecimientos de singular importancia y las fechas pueden variar según la fuente. A partir de 1868, estos periodos o eras coinciden con el reinado de cada emperador. Vives, Historia y arte..., 246.

Puede ampliarse la información al respecto en: «Nippon.com. Una ventana a Japón», Nippon.com, acceso el 7 de febrero de 2021, https://www.nippon.com/es/in-depth/a05403/. También en «Superprof», Equipo Superprof, acceso el 7 de febrero de 2021, https://www.superprof.es/blog/cronologia-historia-japon/.

${ }^{102}$ Fariello, La arquitectura..., 302.

${ }^{103}$ Patrick Vierthaler. «Tenju-an». Flicker.com, 26 de julio, 2016. https://www.flickr.com/photos/pv9007/28080264813/. 
Es un jardín de gran contundencia visual, que incluye arbustos y árboles de gran tamaño en consonancia con el paisaje exterior que lo completa y puede verse por encima de los muros que lo circundan. Como indica Vives: «Las cubiertas de otros edificios del templo, algunos árboles y, finalmente, la frondosa montaña vecina completan la creación de un ambiente impresionante en su conjunto, pero majestuoso y sereno» ${ }^{104}$.

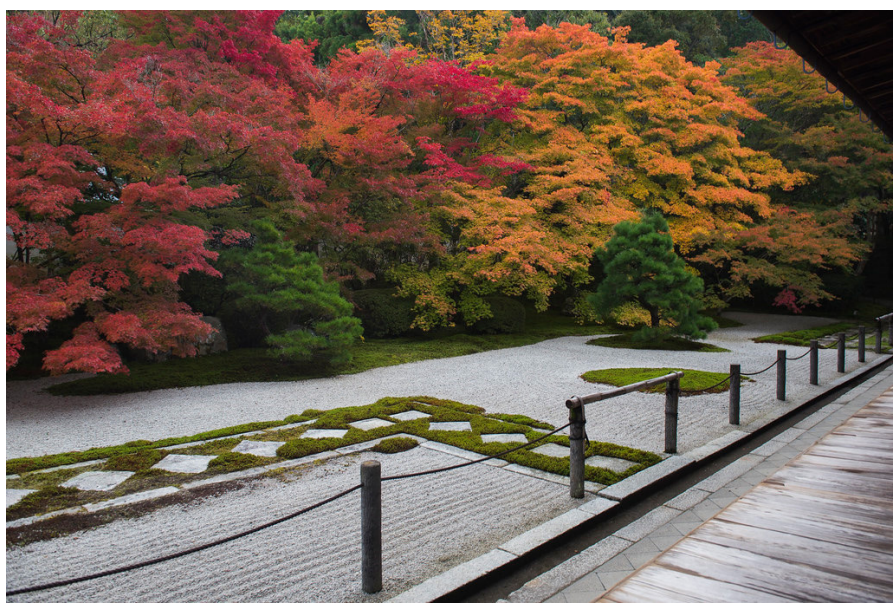

Imagen 4. Vista de Tenju-an en otoño ${ }^{105}$

Además, hay que destacar que el jardín juega con la perspectiva (recurso que después se reflejará en la música de Saariaho): al acceder por la galería puede verse una gran concentración de arbustos y rocas de gran tamaño que van decreciendo conforme se aleja la vista entre las que destaca un pino de altura media ${ }^{106}$. Lo mismo ocurre con el musgo, que se va estrechando; todo ello "parece ser empujado hacia la valla de cierre por un mar de gravilla rastrillada» ${ }^{107}$.

${ }^{104}$ Vives, Historia y arte..., 138-139.

${ }^{105}$ Patrick Vierthaler. «Tenju-an in Autumn». Flickr.com. 10 de noviembre de 2016. https://www.flickr.com/ photos/pv9007/30259219434/sizes/1/.

${ }^{106} \mathrm{El}$ pino es un árbol muy apreciado en Japón, símbolo de fuerza y resistencia, y «símbolo también de los hombres que han sabido conservar intactos sus pensamientos». Chevalier, Diccionario..., 836.

${ }^{107}$ Vives, Historia y arte..., 137. 


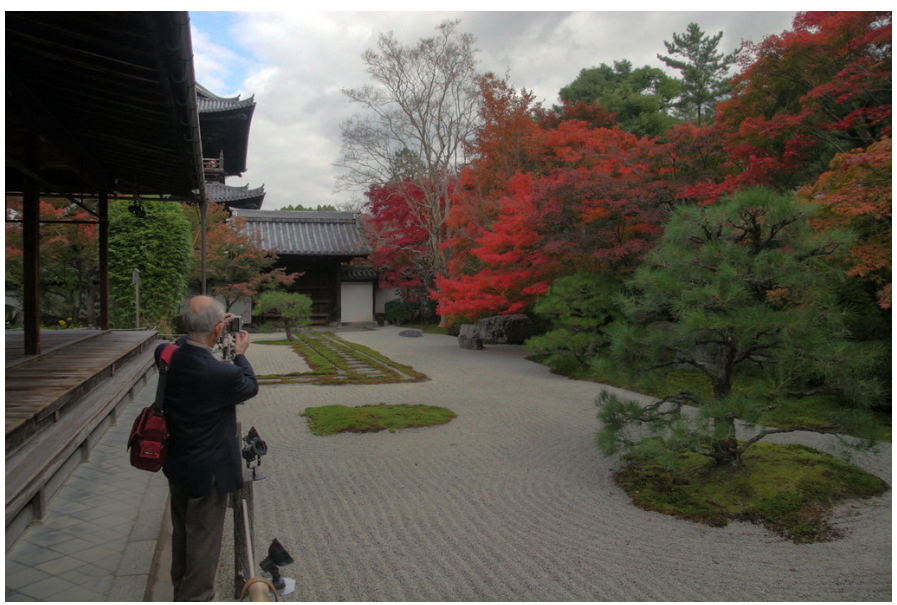

Imagen 5. Vista de Tenju-an desde el propio jardín ${ }^{108}$

III.1.1.1. La pieza

Tabla 2. Generalidad de la pieza I

$\begin{array}{ll}\text { Pieza } & \text { I. Tenju-an garden of Nanzen-ji Temple } \\ \text { Duración } & 03: 10 \\ \text { Instrumentación } & \text { Triángulo, plato suspendido, caja china, pandereta, tambor de hendidura y dos gongs } \\ & \text { Crótalos y timbales } \\ & \text { Electrónica } \\ \text { Tempo/Carácter } & \text { Molto calmo }\end{array}$

Esta obra inicial comienza presentando desde su inicio la orientación que tomará la aplicación de los principios y fundamentos del jardín japonés a lo largo de la composición. La unión de naturaleza y artificiosidad, el principio de lo natural y el ángulo recto forjado por la mano del hombre como una unidad indisoluble, está presente en la electrónica: sonidos naturales manipulados en el estudio. En el caso de Tenju-an, además, se emplean dos objetos sonoros muy concretos: grillos y una voz filtrada, la naturaleza encarnada en el canto del grillo, y el ser humano encarnado en la voz. Ambos objetos se funden en perfecta simbiosis hasta el punto de ser casi indistinguibles el uno del otro.

\section{sizes $/ 1 /$.}

${ }_{108}$ joevare. «Tenju-an 04». Flickr.com. 15 de noviembre de 2010. https://www.flickr.com/photos/joevare/5216603418/ 


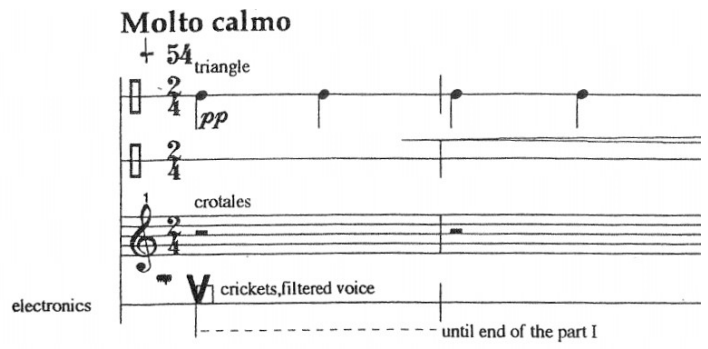

Imagen 6. Inicio de la pieza $I^{109}$

Su sonoridad a pulso constante evidencia una «impresión de ritual idealizado» ${ }^{110}$ en fuerte consonancia con la idea espiritual de la meditación como medio de alcanzar el satori en el budismo zen. Los principios de sencillez y vacío también se manifiestan de una forma evidente con el empleo de un material sumamente simple (la percusión constante a pulso de negra), que apenas ocupa espacio temporal (no existe subdivisión alguna de la figuración en corcheas, semicorcheas, etc.), y con una densidad instrumental baja.

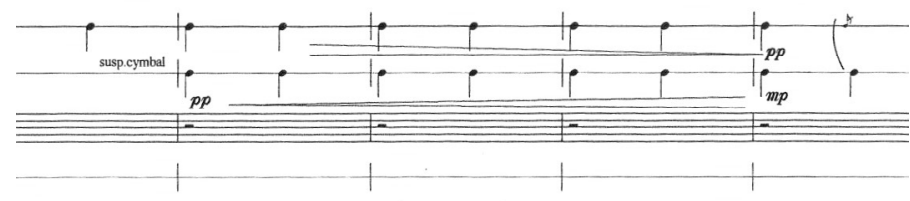

Imagen 7. Ejemplo de la percusión constante a pulso de negra en la pieza I y de la densidad instrumental baja (compases 13 a 17)

Los elementos del jardín encuentran su reflejo en la elección instrumental que guía la atención del oyente como si paseara la vista de derecha a izquierda: la arena y la piedra se plasman a través de los pequeños instrumentos metálicos (triángulo, crótalos, plato suspendido), estos se entremezclan con el musgo (pandereta) que sirve de base a los arbustos (caja china y tambor de hendidura), para finalmente reposar la vista en los árboles (timbales). Los gongs, nexo de unión entre el tambor de hendidura y los timbales, remiten a una llamada a los monjes que tienen que terminar así su meditación, dejando

${ }^{109}$ Todas las imágenes de la partitura proceden de la partitura original de Six Japanese Gardens: Kaija Saariaho, Six Japanese Gardens...

${ }^{110}$ Aracil, Música y..., 203. 
vagar la vista por los últimos rincones del jardín antes de entrar a sus quehaceres en los pabellones del monasterio.

Tabla 3. Asociaciones instrumentales en la pieza I

\begin{tabular}{|c|c|c|c|c|}
\hline Componentes & Instrumentos & Elementos & Color & Simbología \\
\hline Arena y piedra & $\begin{array}{l}\text { Triángulo, crótalos y } \\
\text { plato suspendido }\end{array}$ & Metal (Agua) & Gris & Lo inmaterial \\
\hline Musgo & Pandereta & Tierra & Amarillo & $\begin{array}{c}\text { Mediador entre el cielo y } \\
\text { la tierra }\end{array}$ \\
\hline Arbustos & $\begin{array}{l}\text { Caja china y tambor } \\
\text { de hendidura }\end{array}$ & Madera & Verde & Materia \\
\hline Árboles & Timbales & Fuego & $\begin{array}{c}\text { Rosáceo (cerezos, } \\
\text { ciruelos) y rojo } \\
\text { (arces) }\end{array}$ & Materia - Vida y Felicidad \\
\hline
\end{tabular}

La elección instrumental alude a los cinco elementos de la filosofía china: tierra, madera, fuego, metal y agua ${ }^{111}$. Triángulo, crótalos y plato suspendido aúnan el metal y el agua, asociados al color blanco y negro respectivamente y que se mezclan en el gris de la arena. La pandereta (musgo), empleada como tambor por su «carácter mediador entre el cielo y la tierra» ${ }^{112}$, alude a la tierra, cuyo color es el amarillo. La madera en la caja china y el tambor de hendidura aparecen a continuación, asociados al verde. Y finalmente, los timbales con los tonos rojos y rosáceos de la floración de los árboles culminan en el fuego.

La elección del tipo de instrumento es una expresión simbólica musical de los elementos del jardín e incluso de su color. La arena gris simboliza el agua y se asocia a los instrumentos de metal (esta asociación será recurrente en toda la obra). El musgo se evidencia en una sonoridad mate, la de la pandereta, que remite al sonido amortiguado de los pasos sobre el mismo (no en vano gran parte de los jardines, incluso los más pequeños, están concebidos para poder ser recorridos a pie; son la expresión del Tao, el camino). Los arbustos se encarnan en los pequeños instrumentos de madera y los grandes árboles (ciruelos, cerezos y arces, en tonos que van desde el rosáceo al rojo en flores y hojas) cierran la pieza con la profundidad del sonido de los parches de los timbales. Todo ello puede apreciarse en la tabla 3.

La instrumentación evidencia que lo inmaterial, lo espiritual, representado por los instrumentos de metal, puede alcanzarse en el plano de lo material o terrenal (madera y fuego como símbolos de la

\footnotetext{
${ }^{111}$ En la filosofía tradicional china se encuentran cinco elementos y colores: tierra (centro-amarillo), madera (este-verde), fuego (sur-rojo), metal (oeste-blanco) y agua (norte-negro). Nitschke, El jardín japonés..., 109.

${ }^{112}$ Juan Eduardo Cirlot, Diccionario de símbolos (Barcelona: Labor, 1992), 424.
} 
materia y lo viviente, según Chevalier) ${ }^{113}$ a través de una mediación encarnada en la pandereta. Esta pieza presenta las principales asociaciones que se emplearán en toda la obra y que serán descritas en las siguientes páginas.

Además de lo comentado, el juego de perspectiva se plasma en la parte musical, no solamente direccionando la «mirada» del visitante de derecha a izquierda sino que, al final, los timbales realizan un proceso descendente acentuado por la posición de las alturas: mi-solb-fa (un juego de semitonos que será recurrente en toda la obra, pero subiendo de octava el mi inicial) ${ }^{114}$ así como por el diminuendo.

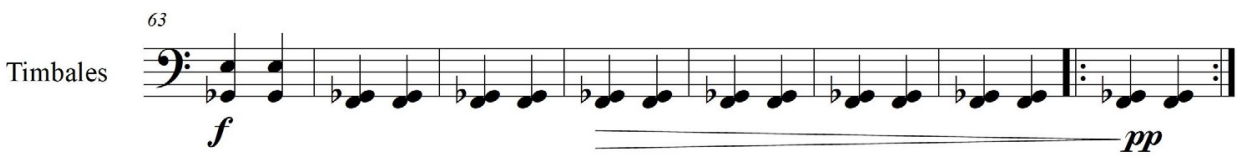

Imagen 8. Reducción del proceso de diminuendo y descenso de los timbales en la pieza I (compases 63 a 70)

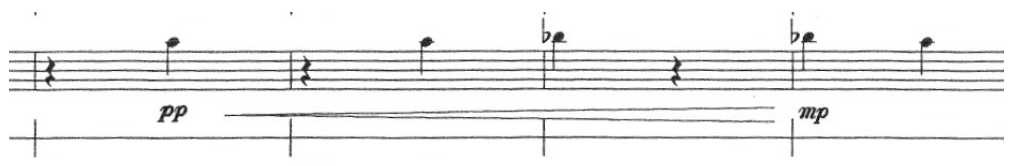

Imagen 9. Parte de los crótalos en los compases 6 a 9 de la pieza I

\section{III.1.2. Many pleasures (Garden of the Kinkaku-ji) ${ }^{115}$}

La segunda pieza de esta obra no hace referencia a un jardín karesansui o seco, sino a un jardín de retiro, es decir, un jardín proyectado como lugar de descanso en la villa de un noble; en concreto, esta villa perteneció al shogun ${ }^{116}$ Ashikaga Yoshimitsu (1358-1408), que fue el principal impulsor de la expansión del budismo zen en Japón durante la era Muromachi (1336-1573). Este jardín es ampliamente conocido dentro y fuera de Japón por su pabellón, el Kinkaku, un edificio de tres plantas de las cuales

${ }^{113}$ Chevalier, Diccionario..., 511 y 673.

${ }^{114}$ El uso de semitonos en los instrumentos afinados será recurrente. Los crótalos se moverán en torno al la (ver compás 6 en la imagen 9) y la afinación inicial de los timbales se mantendrá a lo largo de las tres primeras piezas, cambiando solo para la última (en las piezas IV y V no se utiliza).

${ }^{115}$ Puede encontrarse información de este templo en: «Japonpedia», Kyoko y Jesús, acceso el 8 de febrero de 2021, https://japonpedia.com/templo-dorado-kioto-kinkakuji/.

${ }^{116}$ Shogun es un título militar otorgado a un comandante. En la práctica, los shogunes se convirtieron en dictados militares en la época medieval superando en poder incluso al propio emperador. 
las dos superiores «están recubiertas con láminas de oro puro» ${ }^{117}$. Este pabellón es la base de la historia de la novela El pabellón de oro (1956) de Yukio Mishima, que narra el incendio a manos de un monje enajenado que lo destruyó en 1950, aunque fue reconstruido en $1955^{118}$.

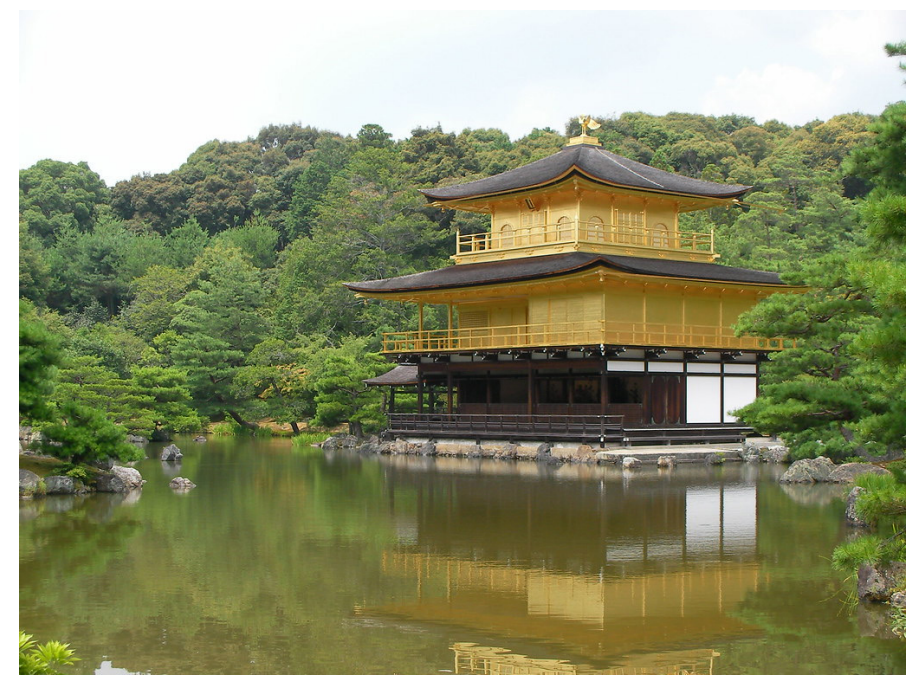

Imagen 10. Vista del pabellón Kinkakư ${ }^{119}$

Este jardín, cuenta con un gran lago (Kyöko-chi o «espejo de agua») frente al pabellón con «numerosas islas y piedras que representan la historia de la creación budista» ${ }^{120}$; varios senderos circundan el lago, pero no es un jardín concebido para ser recorrido a pie, sino que es uno de los pocos que ha de recorrerse en barca (aunque en la actualidad no está permitido, solo puede pasearse por los senderos).

${ }^{117}$ Palacios, «Patrimonio y ...», 8.

${ }^{118}$ Vives, Historia y arte..., 70.

119 Mikel Lizarralde. «Kinkaku-ji». Flickr.com. 1 de agosto de 2008. https://www.flickr.com/photos/ mikeltxo/2730848083/.

${ }^{120}$ Palacios, «Patrimonio y ...»,10. 


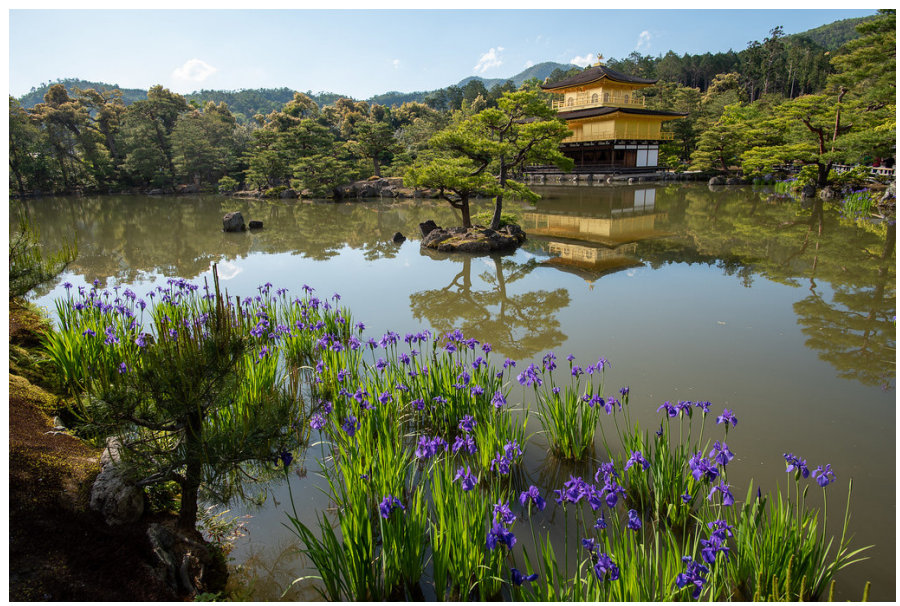

Imagen 11. Vista del lago Kyöko-chi desde el sendero ${ }^{121}$

El Kinkaku-ji cuenta también con un juego de perspectiva al igual que el jardín Tenju-an; la idea es que el lago pareciera de mayores dimensiones, para lo que «se colocaron los elementos de manera que los menores estuvieran más alejados que los mayores» ${ }^{122}$. Cómo puede apreciarse el jardín recorriéndolo por el sendero es descrito gráficamente por Vives en base a estratos:

En primer término, el margen del estanque bordeado por piedras. En el centro, el mayor de los islotes divide la lámina de agua en dos franjas [...]. A su derecha, una península [...]. A continuación emergen algunas rocas frente al pabellón. Y como insuperable telón de fondo de todo el conjunto, las montañas lejanas. Finalmente $[\ldots]$ puede descubrirse una cascada $[\ldots]$, que cae por entre un grupo de piedras. ${ }^{123}$

121 Patrick Vierthaler. «Kinkaku». Flickr.com. 9 de mayo, 2019. https://www.flickr.com/photos/ pv9007/49878060117/sizes/1/.

${ }^{122}$ Vives, Historia y arte..., 68.

${ }^{123}$ Vives, Historia y arte..., 68-69. 


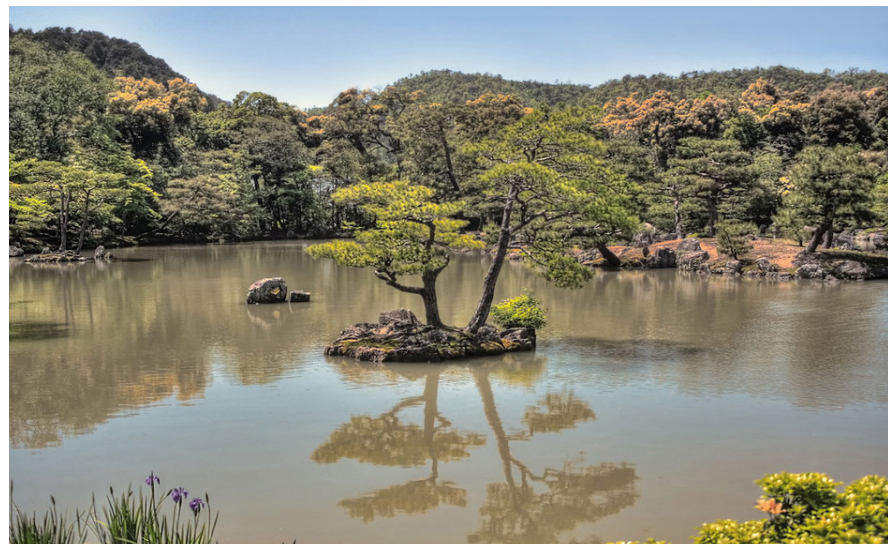

Imagen 12. Vista del estanque donde se aprecia el islote mayor y la península ${ }^{124}$

III.1.2.1. La pieza

Tabla 4. Generalidad de la pieza II

\begin{tabular}{ll} 
Pieza & II. Many pleasures (Garden of the Kinkaku-ji) \\
\hline Duración & $01: 18$ \\
Instrumentación & Tres crótalos (no afinados) suspendidos y placa de metal \\
& Timbales \\
& Electrónica \\
& Intenso, dolce
\end{tabular}

En esta segunda pieza, hay que destacar en primer lugar que el lago que ocupa la mayor parte del jardín se ve reflejado en un empleo mayoritario de instrumentos metálicos, incluso en la parte electrónica (compuesta por cantos budistas y crótalos). Este lago, denominado «el Espejo del Océano» ${ }^{125}$, refleja el preeminente color dorado del propio pabellón.

El agua se encarna por un lado en los tres crótalos suspendidos, cuya presencia es casi constante a lo largo de la pieza. La placa de metal («metal plate») también aparece asociada al agua, pero con un timbre menos cristalino, más opaco; y su unión en determinados puntos (véase imagen 13) con los timbales (asociados simbólicamente a los árboles como explicamos en la primera pieza), en un timbre mixto y resonante, parece representar a los islotes que salpican el agua del estanque.

${ }^{124}$ Daniel Mennerich. «Kyoto J - Kinkaku-ji - Great Pond». Flickr.com. 5 de mayo de 2015. https://www.flickr. com/photos/danielmennerich/24549139674/.

${ }^{125}$ Gras Balaguer, El jardín japonés..., 451. 


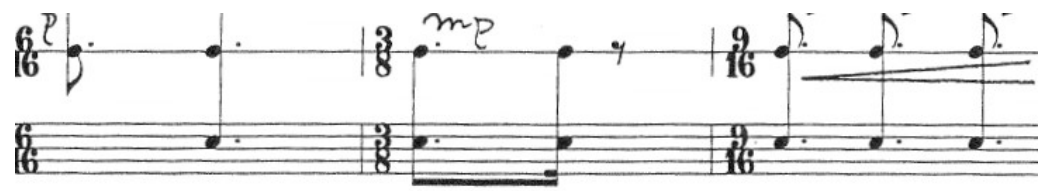

Imagen 13. Timbre mixto formado por el timbal y la placa metálica en la pieza II (compases 14 a 16)

El juego de estratos al que aludía Vives en su descripción es evidente en los procesos asimétricos de evolución de las diferentes líneas. En primer lugar, la línea de los tres crótalos comienza con un diseño habitual de tres semicorcheas ascendentes (véase imagen 14) que, poco a poco, va evaporándose y decelerando en su figuración en un proceso escalonado hasta el compás 27, como puede apreciarse en la imagen 15. A continuación, esta línea recupera el ritmo inicial, para encarar nuevamente el mismo proceso hasta el compás 52 y, a continuación, retrogradarlo hasta el final.

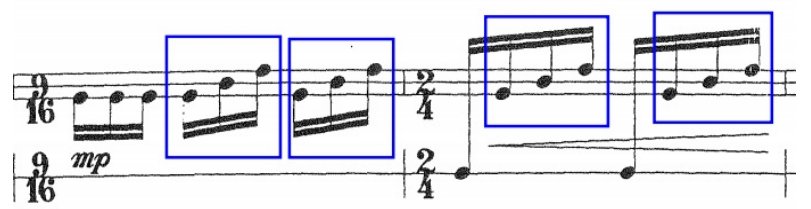

Imagen 14. Ejemplo del diseño de tres semicorcheas de los crótalos en la pieza II (compases 3-4)

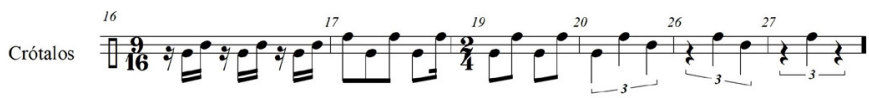

Imagen 15. Reducción del proceso de evaporación y deceleración figurativa de los crótalos en la pieza II entre los compases 16 y 27

La línea de la placa metálica, si bien es más estable, también realiza dos procesos de deceleración figurativa y evaporación: uno de ellos se inicia en el compás 19 y culmina en el compás 28, y el segundo comienza en el compás 47, culmina en el compás 51 y retrograda el proceso para estabilizarse nuevamente en corcheas.

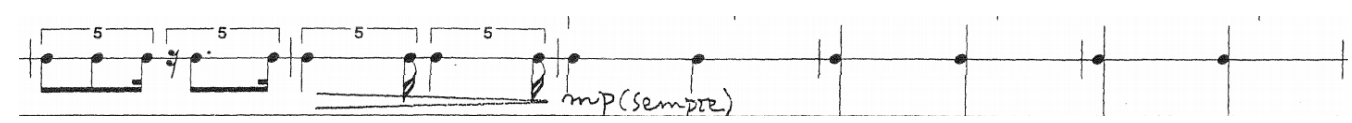

Imagen 16. Proceso de la placa metálica entre los compases 47 y 51 
Los procesos de ambas líneas y su carácter asimétrico pueden apreciarse mejor en la siguiente tabla:

Tabla 5. Evolución asimétrica de las dos líneas superiores en la pieza II

\begin{tabular}{|c|c|c|c|c|c|c|c|c|c|c|}
\hline \multirow[t]{2}{*}{ Instrumentos } & \multicolumn{10}{|c|}{ Compases } \\
\hline & 10 & 19 & 27 & 28 & 37 & 47 & 51 & 52 & 53 & 59 \\
\hline Crótalos & \multicolumn{8}{|c|}{$\begin{array}{l}\text { Deceleración y } \\
\text { Evaporación }\end{array}$} & \multicolumn{2}{|c|}{ Retrogradación } \\
\hline Placa metálica & \multicolumn{5}{|c|}{ Deceleración y Evaporación } & $\begin{array}{l}\text { De } \\
\text { Eve }\end{array}$ & $\begin{array}{l}\text { ación } \\
\text { ción }\end{array}$ & \multicolumn{3}{|c|}{ Retrogradación } \\
\hline
\end{tabular}

Los timbales, por su parte, con la misma afinación que en la pieza I, tienen una aparición puntual en tres formas diferentes: en un timbre mixto con ataque a la vez que la placa de metal (compases 14-16, compases 25-28 y compases 50-51), sustituyendo a la placa metálica en la polirritmia ${ }^{126}$ creada desde el compás 34 con los crótalos a partir del compás 46, y alternando con la placa en los compases 55-57 (imagen 17). El número 3 (tanto en los modos de utilización de los timbales como en el número de crótalos empleados) alude a la representación triádica de Buda y sus ayudantes que se guarda en el Pabellón: la denominada Tríada Shaka.

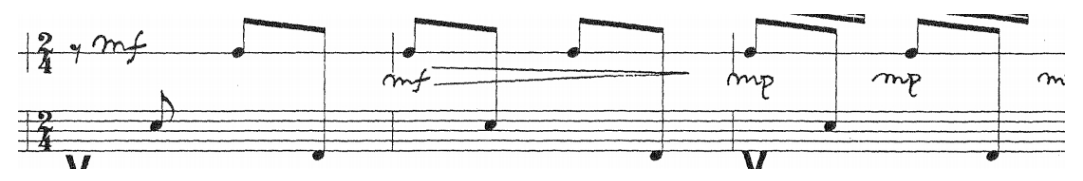

Imagen 17. Alternancia de la placa metálica con los timbales en los compases 55 a 57

La electrónica, a su vez, es un fiel reflejo del sentido espiritual del jardín en una doble vertiente ya que, aunque originariamente el jardín y el pabellón fueron propiedad de un shogun, a su muerte se convirtieron en templo budista zen. Como ocurriera en la primera pieza, Saariaho aúna lo natural y lo artificial, en este caso, el paisaje con la presencia humana a través de los cantos.

Además de lo anteriormente explicado, la elección instrumental también alude al propio Pabellón de Oro. Este consta de tres plantas, las dos superiores recubiertas de pan de oro y la inferior «es básicamente una gran habitación rodeada por una veranda» ${ }^{127}$. Este contraste arquitectónico se plasma en los dos pentagramas superiores con los instrumentos de metal (plantas doradas) y en el pentagrama inferior con los timbales (planta baja) en claro contraste tímbrico.

${ }^{126}$ La polirritmia es la superposición de varias líneas o esquemas rítmicos encontrados, como el cinquillo inicial de los crótalos superpuesto a las corcheas del grupo percusivo inferior.

${ }^{127}$ Palacios, «Patrimonio y...», 8. 
Por último, hay que comentar que todos los elementos emanan el carácter espiritual del jardín. Siguiendo a Chevalier, el agua simboliza el origen de la vida, las islas un centro espiritual y los árboles la vida en proceso, como camino de ascenso ${ }^{128}$. Las repeticiones de carácter ritualista, las líneas en constante evolución, la elección instrumental y los cantos budistas son la respuesta de Saariaho a esta espiritualidad; a ello, hay que añadirle el predominio del reflejo dorado del pabellón en el lago. El oro, como indica Chevalier, «tiene el brillo de la luz», es «el símbolo del conocimiento», «es la inmortalidad $»^{129}$. Instrumentalmente, esto se manifiesta en el predominio metálico, incluso en la parte electrónica.

Tabla 6. Asociaciones instrumentales en la pieza II

\begin{tabular}{|c|c|c|c|c|}
\hline Componentes & Instrumentos & Elementos & Color & Simbología \\
\hline Agua & $\begin{array}{l}\text { Crótalos y placa } \\
\text { metálica }\end{array}$ & Metal (agua) & $\begin{array}{l}\text { Dorado (como } \\
\text { reflejo) }\end{array}$ & $\begin{array}{l}\text { Lo inmaterial - Origen de } \\
\text { la vida }\end{array}$ \\
\hline Islotes & $\begin{array}{l}\text { Placa } \\
\text { metálica+timbales }\end{array}$ & Tierra y madera & Amarillo y verde & Centro espiritual \\
\hline Árboles & Timbales & Madera & Verde & $\begin{array}{c}\text { Evolución - Ascenso al } \\
\text { cielo }\end{array}$ \\
\hline
\end{tabular}

\section{III.1.3. Dry mountain stream}

El jardín Tenryūji es un caso de jardín de retiro (de una villa imperial) como el precedente Kinkaku-ji reutilizado como templo, aunque con una reforma encargada por el shogun Ashikaga Tadayoshi (1306-1352) al que sería el futuro prior, Musō Soseki (1275-1351). Este jardín era originalmente un jardín de agua, con un estanque en el que se podía pescar; Soseki lo innovará incluyendo composiciones de piedra que lo convertirán en un jardín para ser contemplado ${ }^{130}$.

Tenryü-ji se compone de tres estratos que Vives describe desde el punto de vista de un observador situado en las dependencias del abad. En el primer estrato estaría el estanque original rodeado de vegetación y algunas rocas, separado del propio edificio por arena; además, «una península surge de su margen derecho [del estanque] apuntando a un peñasco aislado en el agua. Un poco más allá, surge un islote con un pino y un arce» ${ }^{131}$.

\footnotetext{
${ }^{128}$ Chevalier, Diccionario..., 52.

${ }^{129}$ Chevalier, Diccionario..., 174.

${ }^{130}$ Vives, Historia y arte..., 62-63.

${ }^{131}$ Vives, Historia y arte..., 63.
} 


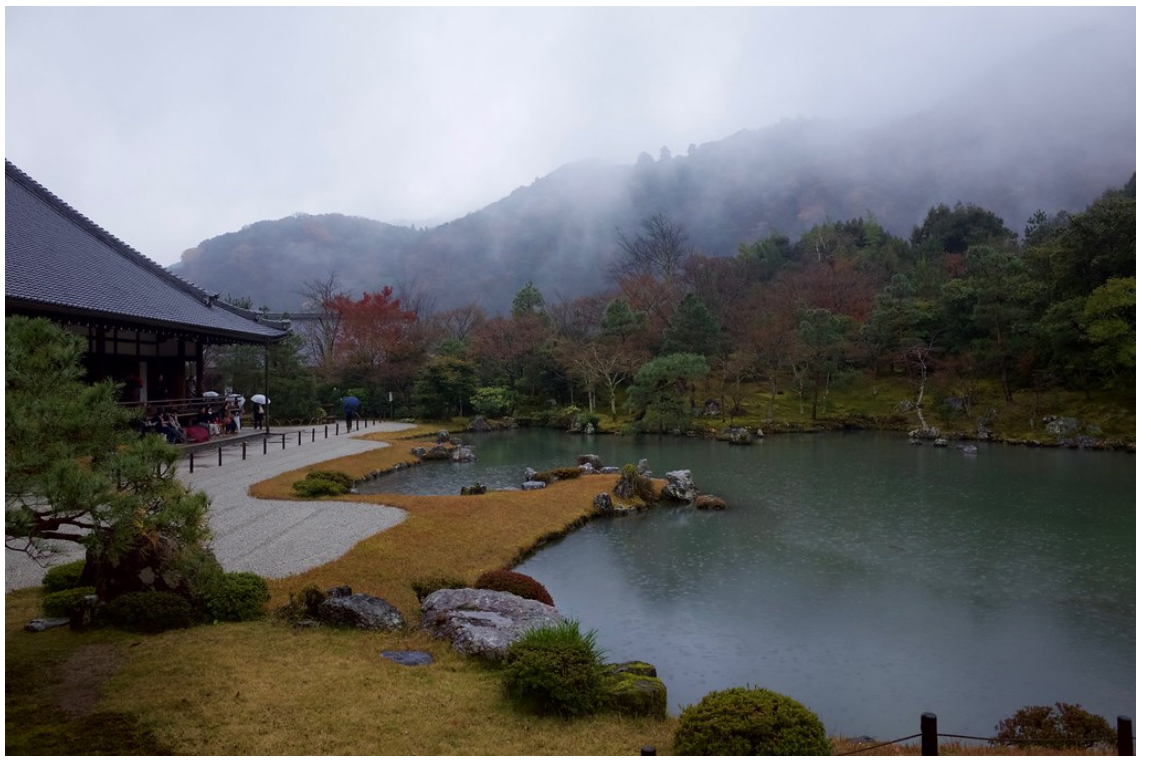

Imagen 18. Estanque original de Tenryü-ji $i^{132}$

El segundo nivel es el compuesto por rocas y añadido por Soseki. En el centro hay una cascada de rocas cuyo inicio permanece oculto entre los árboles. En medio de esta cascada se sitúa una piedra alargada que alude a una carpa, símbolo de perseverancia. En la parte inferior tres rocas asemejan un puente ${ }^{133}$; a la derecha, otras piedras simbolizan los míticos montes Sumeru y Hōrai1 ${ }^{134}$; a la izquierda, más rocas recuerdan a un embarcadero (en total este nivel tiene a su vez otros tres estratos).

132 tablexxnx. «Tenryū-ji». Flickr.com. 13 de diciembre de 2016. https://www.flickr.com/photos/ tablexxnx/31080795863/.

${ }^{133}$ Cabañas, «Un puente ...», 245.

${ }^{134} \mathrm{El}$ monte o isla Hōrai es un símbolo de la Isla de los Bienaventurados. Esta idea deriva de la reducción a una sola isla de la creencia mitológica china en «cinco islas donde los hombres han alcanzado la inmortalidad y conviven en eterna armonía [...]. Los inmortales vuelan alrededor de la cumbre de la montaña montados en grullas. Las islas se asientan sobre el caparazón de una gigantesca tortuga acuática». Nitschke, El jardín japonés..., 23. De aquí nace también la adopción de la grulla y la tortuga como símbolos de la longevidad. 
M. ${ }^{a}$ DOLORES ROMERO ORTIZ. EL JARDÍN JAPONÉS EN SIX...

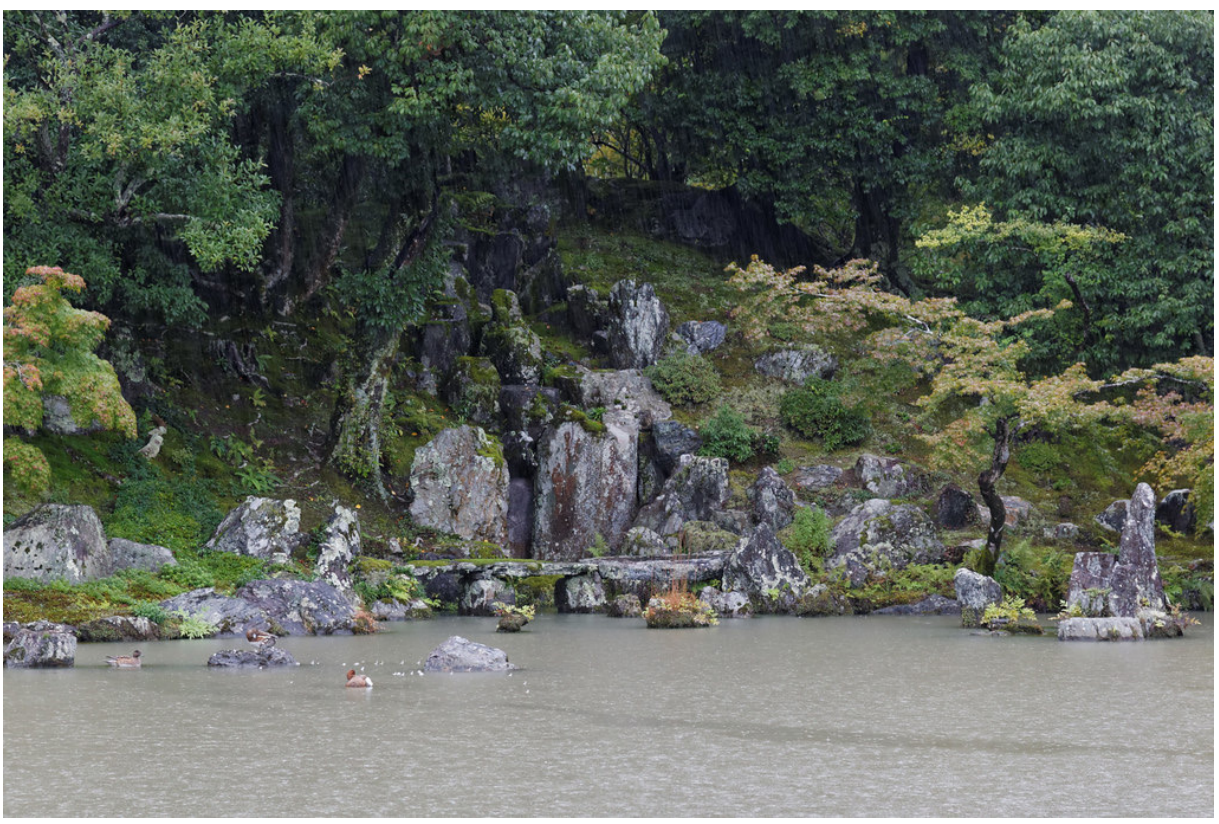

Imagen 19. Segundo nivel de Tenryü-jï ${ }^{135}$

El último nivel está compuesto por las montañas, las cuales no aparecen separadas del jardín por ningún tipo de valla o muro, sino que se integran en la composición en una emulación de la pintura paisajística china de la dinastía Song (960-1279), conocida por Soseki, y en la que habitualmente «predomina la verticalidad, [...] donde a menudo se representan cumbres de formas redondeadas semiocultas por nubes y niebla» ${ }^{136}$.

${ }_{135}$ Kimon Berlin. «Tenryū-ji». Flicker.com. 25 de octubre de 2013. https://www.flickr.com/photos/ kimon/11096331744/.

${ }^{136}$ Vives, Historia y arte..., 63. 


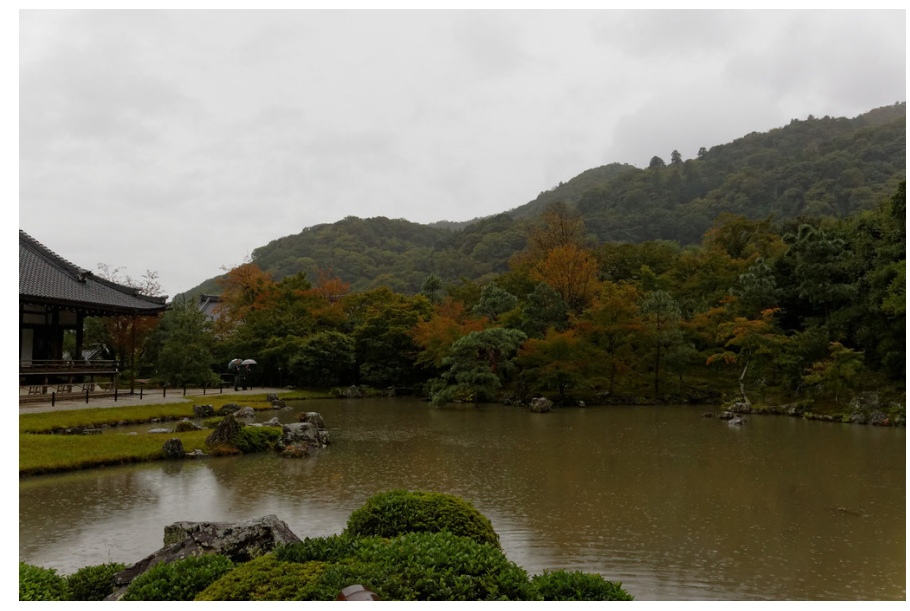

Imagen 20. Último nivel de Tenryü-ji $i^{137}$

III.1.3.1. La pieza

Tabla 7. Generalidad de la pieza III

\begin{tabular}{ll} 
Pieza & III. Dry mountain stream \\
\hline Duración & 03:02 \\
Instrumentación & Madera, parche y piedra (altura indeterminada) \\
& Tam-tam, gong \\
& Timbales \\
& Electrónica \\
& Sempre energico
\end{tabular}

Lo que más llama la atención en esta pieza es la referencia constante al número 3, fiel reflejo de la doble composición tripartita del jardín. Este número tres, símbolo de lo asimétrico, aparece en primer lugar reflejado en la instrumentación, donde el primer grupo está compuesto de tres instrumentos a elegir por el intérprete de madera, parche y piedra; pero sobre todo, aparece evidenciado una y otra vez en el material musical. Este constantemente se compone de diseños de tres elementos o de repeticiones en múltiplos de tres. Para ilustrarlo, en el siguiente ejemplo (imagen 21) se reproducen los compases 20 a 22, donde las alturas del timbal se agrupan en tres (fa-sol-mib) y se repiten tres veces, igual que el

${ }^{137}$ Kimon Berlin. «Tenryūji». Flickr.com. 25 de octubre de 2013. https://www.flickr.com/photos/ kimon/11096238195/sizes/1/. 
diseño del primer grupo percusivo y la figura combinatoria de gong y fa de timbal. Un golpe de gong rompe la simetría del conjunto.

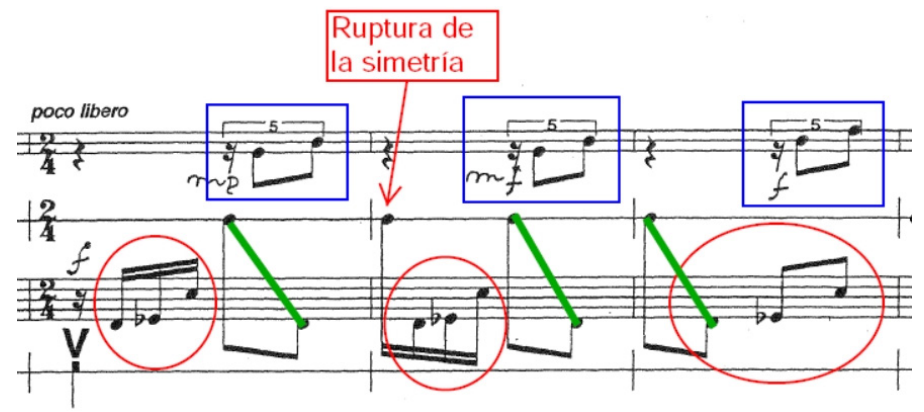

Imagen 21. Referencias al número 3 en los compases 20-22 en la pieza III

Por otro lado, nuevamente Saariaho parece dirigir la mirada del espectador, en este caso al oyente, desde las montañas lejanas hasta el estanque y de regreso a las montañas: la pieza comienza con un diseño que visualmente parece ascender y luego descender, apoyado por la dinámica que crece hasta el forte en el compás 8 y posteriormente decrece al mp en el compás 11 en una evocación de la montaña (imagen 22); a continuación, se nos dirige hacia la cascada de piedra en dos violentos diminuendi desde el ff a partir del compás 31 y, un diseño de carácter descendente entre el primer grupo percusivo y el fa del timbal (imagen 23).
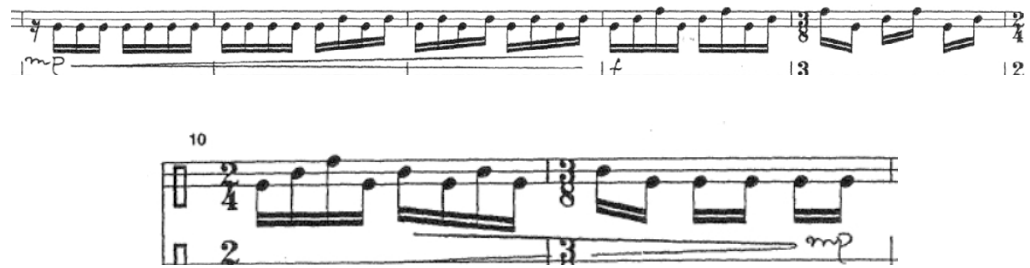

Imagen 22. Evocación de la montaña (madera, parche y piedra en los compases 5 a 11) en la pieza III

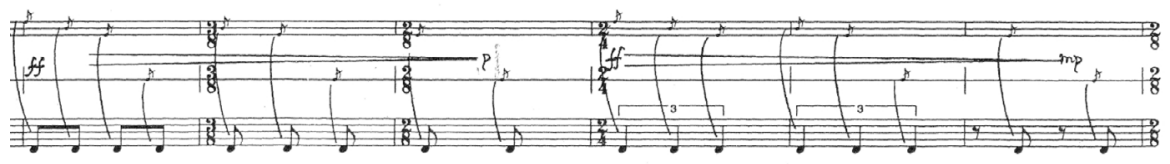




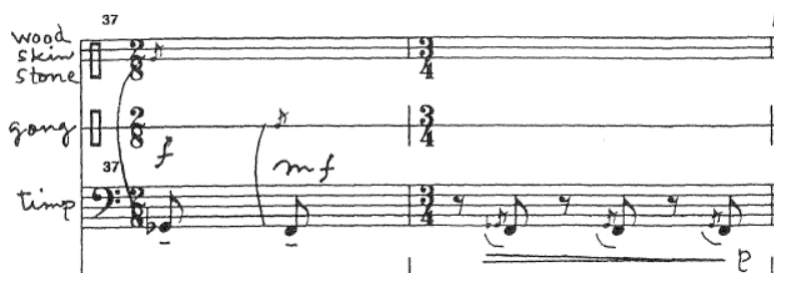

Imagen 23. Cascada de piedra (primer grupo percusivo y timbal en los compases 31 a 38) en la pieza III

La segunda página es una parte que entremezcla momentos polirrítmicos (compases 39-41 y compases 63, 65 y 67, ver imagen 24) con un recuerdo de la cascada de piedra (compases 51-57), todo ello junto a la constante alusión al número 3 , en referencia al segundo estrato del jardín donde aparecen el embarcadero, la cascada y las rocas de las islas de los inmortales.

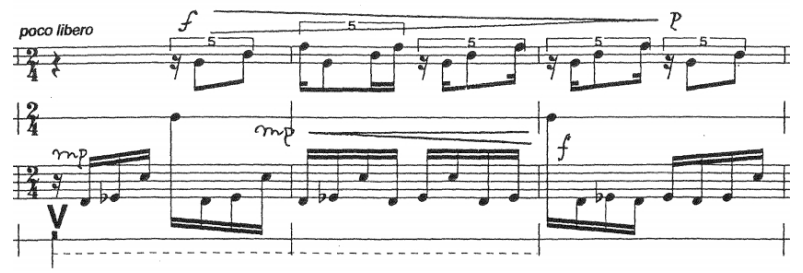

Imagen 24. Ejemplo de polirritmia (compases 39-41) en la pieza III

Todo ello lleva a la tercera página, donde el gong, insinuación del agua del estanque (y en ocasiones el timbal) tiene una presencia constante (alusión también a la perseverancia de la carpa) junto al diseño de cinquillo del primer grupo percusivo, en alegoría de la presencia de los restantes elementos del jardín (imagen 25); finalmente, a partir de la cuarta página, el material vuelve a regularizarse recordando el inicial y llevándonos de vuelta a las montañas lejanas (imagen 26). La electrónica únicamente refuerza la sonoridad metálica de la pieza.

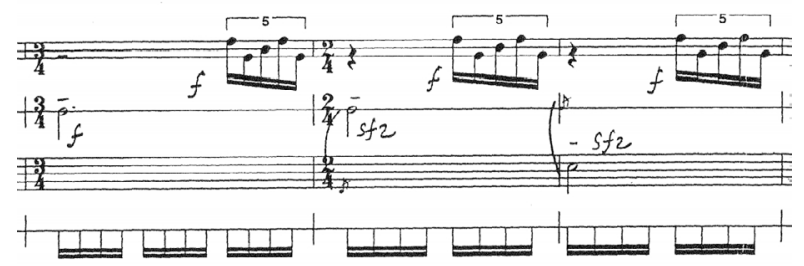

Imagen 25. Compases 87 a 89 en la pieza III 


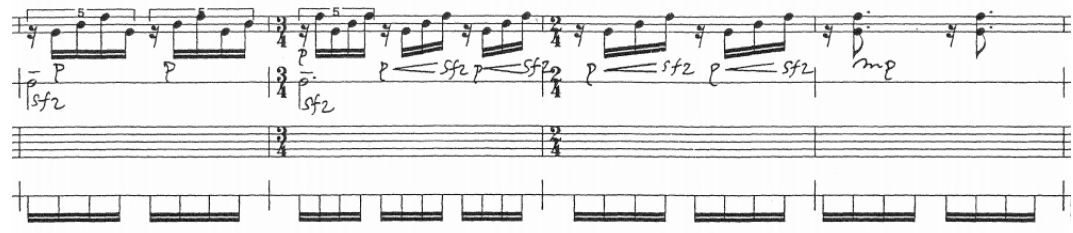

Imagen 26. Compases 103 a 106 en la pieza III

En cuanto a la simbología de la elección instrumental, esta continúa remitiendo a los cinco elementos de la filosofía china clásica y al carácter espiritual del jardín japonés: el agua se sitúa como origen de la vida ${ }^{138}$ tanto en su versión real (estanque) como metafórica (cascada de piedras); la resistencia y la perseverancia están presentes también en la figura de la carpa y en el pino; la montaña, manifestada en el primer grupo percusivo, representa «el encuentro del cielo y la tierra, la morada de los dioses y el término de la ascensión humana» ${ }^{139}$. Si se aúnan los símbolos de las familias instrumentales de este grupo se encuentra: la madera como materia, punto de comienzo de la ascensión ${ }^{140}$; el parche (originalmente, la piel) como símbolo de nacimiento y renacimiento ${ }^{141}$ mientras que la piedra es la unión y la fuerza ${ }^{142}$; todo ello conforma en su conjunto la unión de lo humano y lo divino a la que se aludía, en la figura de la montaña, al camino de ascenso desde la materia, a través de la fuerza y la perseverancia, para alcanzar un renacimiento espiritual.

Tabla 8. Asociaciones instrumentales en la pieza III

\begin{tabular}{|c|c|c|c|c|}
\hline Componentes & Instrumentos & Elementos & Color & Simbología \\
\hline $\begin{array}{c}\text { Árboles, vegetación y } \\
\text { arena }\end{array}$ & $\begin{array}{c}\text { Madera, parche y } \\
\text { piedra }\end{array}$ & Madera y fuego & $\begin{array}{l}\text { Verde y rojo (pino y } \\
\text { arce), verde y gris }\end{array}$ & $\begin{array}{l}\text { Montaña } \\
\text { Resistencia }\end{array}$ \\
\hline Agua & Tam-tam y gong & Metal (agua) & $\begin{array}{c}\text { Reflejo de los } \\
\text { demás, rojo (carpa) }\end{array}$ & $\begin{array}{l}\text { Origen de la vida } \\
\text { Perseverancia }\end{array}$ \\
\hline Grandes piedras & Timbales & Agua & Gris & Origen de la vida \\
\hline
\end{tabular}

${ }^{138}$ Chevalier, Diccionario..., 53.

${ }^{139}$ Chevalier, Diccionario..., 722.

${ }^{140}$ Chevalier, Diccionario..., 673.

${ }^{141}$ Cirlot, Diccionario..., 363.

${ }^{142}$ Cirlot, Diccionario..., 362. 


\section{III.1.4. Rock garden of Ryōan-ji}

Ryōan-ji es quizá uno de los jardines japoneses más célebres ${ }^{143}$ y que más interpretaciones ha suscitado entre estudiosos y artistas. Como indica Cabañas:

Ryōanji, el «templo del dragón apacible», al noreste de Kyoto es quizá el ejemplo más emblemático por su pureza: ningún elemento acuático, ningún arbusto ni árbol, y posee un rasgo constante en la estética japonesa: la simbiosis figurativa del ángulo recto y la forma natural. ${ }^{144}$

Este jardín de un templo de Kioto, que data de 1459, es un jardín puramente seco, construido ex profeso como herramienta de meditación en el marco del budismo zen, «con una fuerte carga psicológica cuyo aislamiento y quietud respecto a todo incita a la introspección» ${ }^{145}$; de hecho, «el escritor francés Paul Claudel dijo que la entrada a este recinto solitario pone al visitante en presencia de la eternidad ${ }^{146}$.

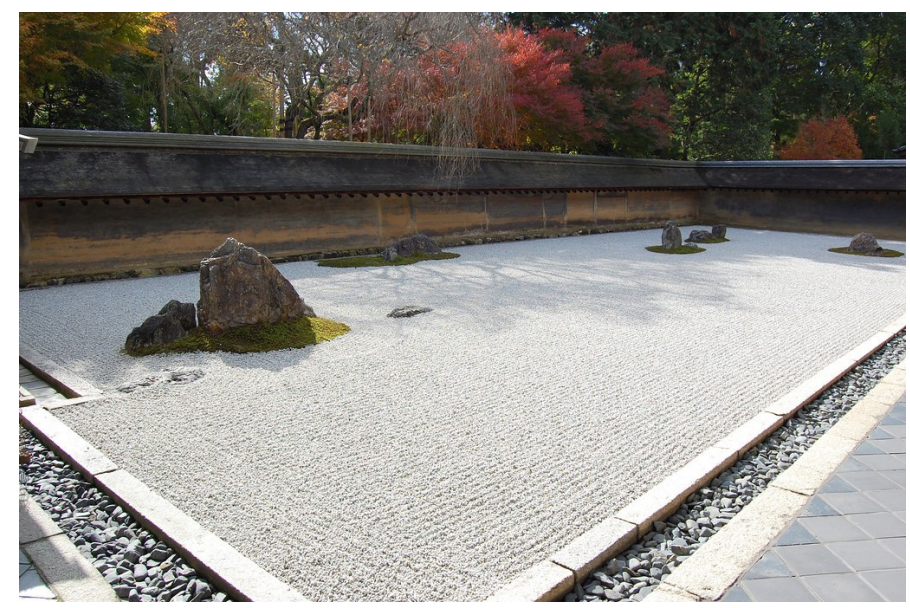

Imagen 27. Vista de Ryōan-ji ${ }^{147}$

${ }^{143}$ Puede obtenerse información a través de su página web oficial: «Ryoanji», Ryoanji Temple, acceso el 8 de febrero de 2021, http://www.ryoanji.jp/smph/eng/.

${ }^{144}$ Cabañas, «Un puente ...», 248.

${ }^{145}$ Francesc Pedragosa, «Interior/exterior en el espacio arquitectónico japonés», DPA: Documents de Projectes d'Arquitectura 13 (1997): 4.

${ }^{146}$ Fariello, La arquitectura..., 293.

147 clio1789. «Ryōan-ji». Flickr.com. 21 de noviembre de 2012. https://www.flickr.com/photos/ clio1789/8240124400/. 
Ryōan-ji es un modesto recinto rectangular de 24 x 9 metros encuadrado por dos lados por el propio monasterio y por los otros dos por un muro. Todo el suelo está cubierto de arena blanca en surcos con «un diseño general de líneas rectilíneas y paralelas a la galería del edificio y otro de surcos concéntricos que rodean a los grupos [de piedras] $\rangle^{148}$. Sobre este suelo destacan 15 piedras, repartidas según Fariello ${ }^{149}$ y Vives ${ }^{150}$ en cinco grupos y según otros autores en tres grupos de dos, tres y cinco, o bien de siete, cinco y tres ${ }^{151}$, en una composición asimétrica. Curiosamente «tiene la particularidad de que, desde cualquier punto, la visión nunca abarca más de catorce piedras, ya que la decimoquinta siempre queda oculta por alguna de las otras» ${ }^{152}$. El único elemento vegetal que encontramos es el musgo que recubre parcialmente algunas rocas y las cerca.

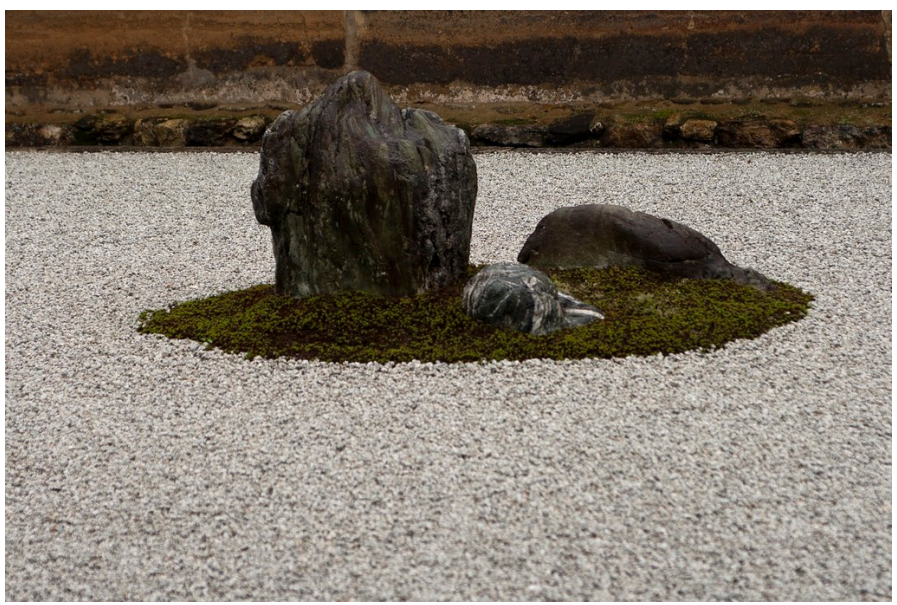

Imagen 28. Detalle de grupo de tres piedras y musgo de Ryōan-ji $i^{153}$

Como era comentado más arriba, este jardín ha sido interpretado de numerosas formas: un mar con sus islas, picos de montaña, o, según una leyenda china, tigres atravesando un valle ${ }^{154}$. En todo caso, tal como afirma Cabañas:

${ }^{148}$ Vives, Historia y arte..., 78.

${ }^{149}$ Fariello, La arquitectura..., 293.

${ }^{150}$ Vives, Historia y arte..., 78.

${ }^{151}$ Cabañas, «Un puente ...», 249; y Nitschke, El jardín japonés..., 90.

${ }^{152}$ Fariello, La arquitectura..., 293.

${ }^{153}$ mattlucht. «Ryoanji Temple zen garden (2)». Flickr.com. 5 de octubre de 2011. https://www.flickr.com/ photos/mattlucht/6213863279/.

${ }^{154}$ Fariello, La arquitectura..., 293. 
Esto tiene mucha relación con el mundo del arte contemporáneo, donde el artista deja abierta la obra a la interpretación del espectador, negándole incluso, al no facilitar un título o referirse a ella como composición, cualquier pista para ayudarle a acercarse a la obra con libertad y sin ningún tipo de condicionamiento, pues de lo que se trata es de que el espectador proyecte su interioridad sobre la obra y dé su propia interpretación, teniendo valor incluso independientemente de lo que el artista haya querido plasmar en su creación. ${ }^{155}$

Vives realiza una interesante comparación entre la composición de los grupos de piedras y una obra musical con introducción, desarrollo y conclusión. A continuación, aparece íntegramente reproducida:

Comenzando por la derecha, el primer grupo es el que está más próximo a la galería. Tiene tres rocas y una de ellas es de gran tamaño. Ese inicio parece una llamada de atención. Los tres conjuntos siguientes son los que están más alejados. La relación entre sus respectivos números de piedras forma un esquema simétrico 2-3-2, mientras que su distancia respecto al edificio crea una cadencia B-A-C. Entre ambos ritmos se genera una polifonía muy variada, con un fuerte acento vertical en el grupo central que puede entenderse como el clímax de una abstracta exposición narrativa. El interludio de ese desarrollo lo personifican las dos rocas más alejadas de todas, su discreta presencia rememora un pianissimo musical. El desenlace llega con la última agrupación de cinco piedras. Como corresponde a una conclusión, su volumen global supera al del resto. En él participan no solo el peñasco mayor de los quince del jardín, sino otros dos que lo arropan ayudándole en su presencia afirmativa y una pareja, algo más alejada, que actúa como el eco de un acorde en fortissimo. ${ }^{156}$

\section{III.1.4.1. La pieza}

Tabla 9. Generalidad de la pieza IV

\begin{tabular}{ll} 
Pieza & IV. Rock garden of Ryōan-ji \\
\hline Duración & $02: 18$ \\
Instrumentación & Plato pequeño, gong y tambor de hendidura \\
& Platos zen y tam-tam \\
& Electrónica \\
Tempo/Carácter & Misterioso, Sempre poco rubato
\end{tabular}

Esta cuarta pieza se construye en sintonía con el jardín que representa: en primer lugar, la ausencia de vegetación se traduce en una elección instrumental sin alturas determinadas, donde las

${ }^{155}$ Cabañas, «Un puente ...», 249-250.

${ }^{156}$ Vives, Historia y arte..., 79-80. 
piedras de la composición paisajística se representan en los propios instrumentos en «un juego de granulosas texturas $\rangle^{157}$. La arena como base continua queda personificada por la electrónica, en la cual vuelven a aparecer las voces de los monjes budistas, acentuando el carácter espiritual de la obra.

La pieza sigue el esquema detallado anteriormente por Vives. Una introducción de cinco compases (compases 2 a 6) trae el primer grupo de tres piedras. La primera, de mayor tamaño, se confía a partir de ahora a un $s f z$ de los platos zen cuya resonancia continúa tocándolos ligeramente (compás 2); las otras dos aparecen como golpe de tam-tam y plato pequeño respectivamente. Este último, en redoble (compás 6), sirve para entrar en la parte de desarrollo (compases 7-33).

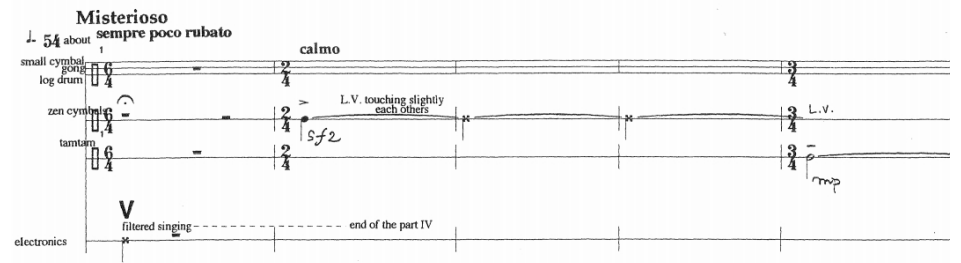

Imagen 29. Inicio de la cuarta pieza (compases 1 a 5)

El desarrollo se divide a su vez en tres partes, la cadencia B-A-C mencionada por Vives y aludida gracias al carácter de cada fragmento: calmo-espressivo (cc. 7-13), poco furioso (cc. 14-17) y calmo-poco a poco più agitato (cc. 18-33). La primera parte, un grupo de dos rocas, se divide en el continuo de gong y plato pequeño (primera roca) puntuado por el tambor de hendidura (segunda roca) con un accelerando de la figuración (imagen 30).
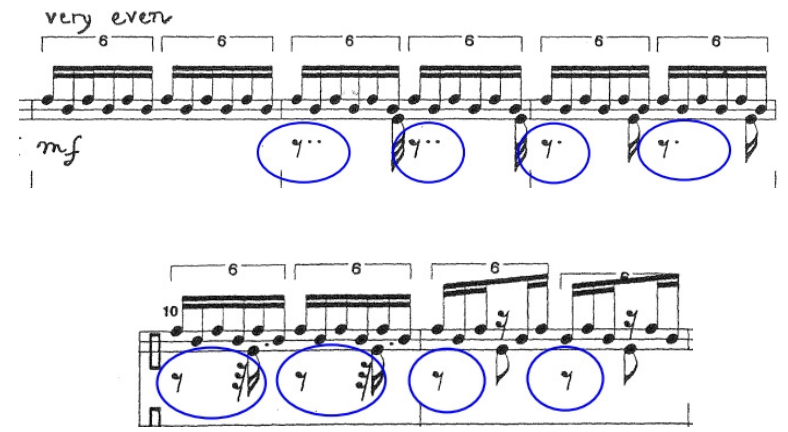

Imagen 30. Accelerando del primer grupo de rocas del desarrollo (compases 8 a 11) en la pieza IV

${ }^{157}$ Aracil, Música y..., 204. 
En la segunda parte (compases 14 a 17), poco furioso, se encuentra el «acento vertical del grupo central» de Vives ${ }^{158}$, nuevamente personificado en un golpe sfz de platos zen.

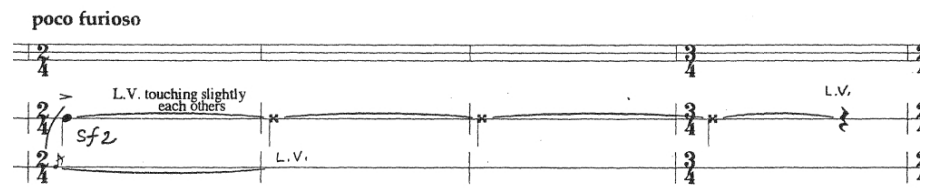

Imagen 31. Parte de los platos zen entre los compases 14 y 17 en la pieza IV

El último fragmento del desarrollo (a partir del compás 18), con el último y más alejado grupo de dos piedras, comienza precisamente con un diseño de dos golpes alternos en $p$ entre el gong y el tambor de hendidura. Este diseño acaba combinado en polirritmia cuando el poco a poco più agitato en el compás 20 conduce hacia la resolución de la pieza (imagen 32).

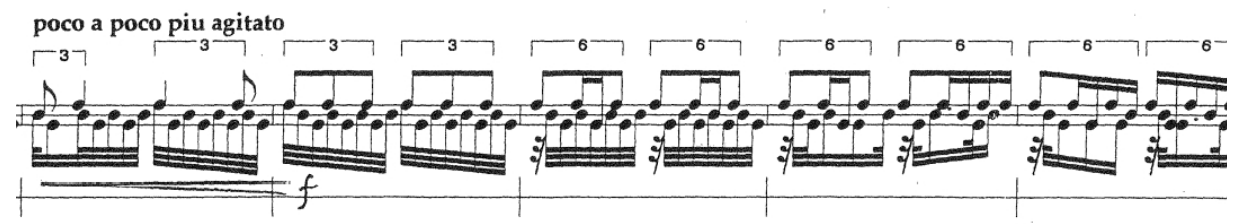

Imagen 32. Polirritmia del desarrollo (compases 20 a 24) en la pieza IV

El final del desarrollo crece incorporando el tam-tam y los platos zen entre los compases 29 y 32, acercándose a la conclusión final precedida de «la discreta presencia» de las dos últimas rocas en $p p$ (gong y tambor de hendidura al final del compás 33, ver imagen 33).

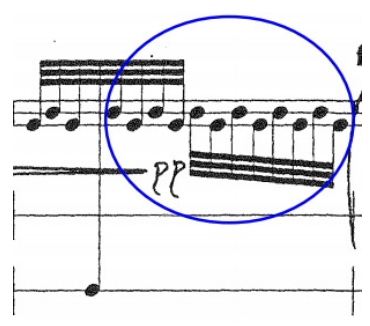

Imagen 33. Interludio entre el desarrollo y la conclusión (final del compás 33) en la pieza IV

${ }^{158}$ Vives, Historia y arte..., 79. 
Para concluir, aparece el último grupo de cinco piedras: la principal representada por los platos zen, las dos piedras circundantes en el tam-tam y el tambor de hendidura, las dos más alejadas en el gong y el plato pequeño (ver imagen 34).

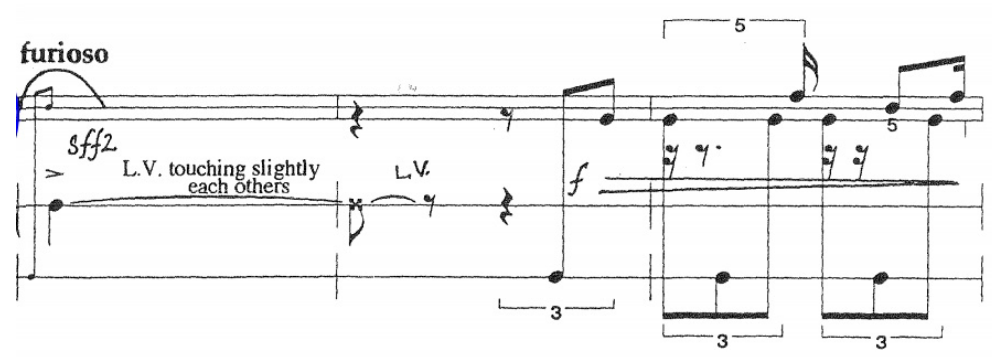

Imagen 34. Último grupo de rocas (compases 34 a 36) en la pieza IV

A continuación, aparece una tabla comparativa entre la estructura musical propuesta por Vives y la pieza de Saariaho.

Tabla 10. Comparativa de estructuras en la pieza IV

\begin{tabular}{|c|c|c|c|c|c|}
\hline \multicolumn{4}{|c|}{ Estructura de Vives } & \multicolumn{2}{|c|}{ Estructura de Saariaho } \\
\hline \multirow{5}{*}{ Inicio } & \multirow{4}{*}{3 rocas } & Roca de gran & \multirow{5}{*}{$\begin{array}{l}\text { Introducción } \\
\text { (cc. 2-6) }\end{array}$} & Sf₹ $\mathrm{pl}$ & \\
\hline & & & & & \\
\hline & & Roca & & Tan & \\
\hline & & Roca & & \multicolumn{2}{|c|}{ Plato pequeño } \\
\hline & B & Roca & & $\begin{array}{l}\text { Calmo espressivo } \\
\text { (cc. } 7-13 \text { ) }\end{array}$ & $\begin{array}{l}\text { Gong y plato } \\
\text { pequeño }\end{array}$ \\
\hline \multirow[t]{6}{*}{ Exposición } & \multirow{4}{*}{$\mathrm{A}$} & & \multirow{4}{*}{$\begin{array}{c}\text { Desarrollo (cc. } \\
7-33)\end{array}$} & \multirow{4}{*}{$\begin{array}{l}\text { Poco furioso } \\
\text { (cc. 14-17) }\end{array}$} & $\begin{array}{l}\text { Tambor de } \\
\text { hendidura }\end{array}$ \\
\hline & & Roca & & & Sfz platos zen \\
\hline & & Roca & & & \\
\hline & & Roca & & & \\
\hline & \multirow[t]{2}{*}{$\mathrm{C}$} & Roca & & \multirow{2}{*}{$\begin{array}{l}\text { Calmo poco a poco più } \\
\text { agitato (cc. 18-33) }\end{array}$} & Gong \\
\hline & & Roca & & & $\begin{array}{l}\text { Tambor de } \\
\text { hendidura }\end{array}$ \\
\hline
\end{tabular}




\begin{tabular}{|c|c|c|c|c|}
\hline \multicolumn{4}{|c|}{ Estructura de Vives } & Estructura de Saariaho \\
\hline & Dos rocas & Roca & Interludio & Gong \\
\hline Interludio & alejadas & Roca & (final c. 33) & Tambor de hendidura \\
\hline Desenlace & 5 rocas & $\begin{array}{l}3 \text { rocas }(f f) \\
2 \text { rocas }(e c o)\end{array}$ & $\begin{array}{c}\text { Conclusión } \\
\text { (cc. 34-40) }\end{array}$ & $\begin{array}{c}\text { Platos zen, tam-tam y tambor de hendidura } \\
\text { Gong y plato pequeño }\end{array}$ \\
\hline
\end{tabular}

Añadido a todo lo anterior es de destacar la importancia atribuida al número 3: este aparece representado en la elección tripartita del primer grupo percusivo (plato pequeño, gong y tambor de hendidura) así como en los tres golpes con los que se inicia la pieza (platos zen, tam-tam y plato pequeño en los compases 2 a 6 ) y con los tres con los que se cierra (platos zen en los compases 33 a 40). Además en las figuraciones irregulares predomina claramente el tresillo y el seisillo, y no será hasta la última parte cuando aparezca una figura diferente: el cinquillo.

Desde el punto de vista de la simbología de la elección instrumental, todos son instrumentos metálicos, aludiendo a la roca y al agua, a excepción del tambor de hendidura, elemento de ruptura que encarna el musgo. Por otro lado, es la primera y única vez que la electrónica forma parte de este juego simbólico, es la arena que sustenta el jardín.

Tabla 11. Asociaciones instrumentales en la pieza IV

\begin{tabular}{|lllll} 
Componentes & Instrumentos & Elementos & Color & Simbología \\
\hline Piedras & $\begin{array}{l}\text { Plato pequeño, gong, } \\
\text { platos zen y tam-tam }\end{array}$ & Metal & Gris (blanco y negro) & Lo inmaterial \\
Musgo & Tambor de hendidura & Madera y tierra & Verde y amarillo & La materia \\
Arena & Electrónica & Agua & Gris & Origen de la vida
\end{tabular}

Además, el vacío juega en esta pieza un importante papel. La textura aireada que inaugura cada una de las partes de la pieza evidencia un rol estructural único en esta parte de la obra.

\section{III.1.5. Moss garden of the Saiho-ji}

Esta quinta pieza de Six Japanese Gardens se inspira en el jardín seco del templo budista zen de Saiho-ji, situado en Kioto ${ }^{159}$. Este jardín es conocido por su sobrenombre koko-dera, es decir, «templo del musgo», ya que casi todo el terreno se encuentra cubierto de más de cien variedades de musgo. Saibo-ji es uno de los jardines más antiguos que se conservan en Japón y fue construido por el maestro

${ }^{159}$ Puede visitarse la página oficial en inglés del templo en la dirección: «Saihoji», SAIHOJI, acceso el 9 de febrero de 2021, http://saihoji-kokedera.com/en/top.html. 
de jardines Musō Soseki, «padre del tipo karesansui»» ${ }^{160}$ entre los años 1339 y 1344 (era Muromachi). El templo ya existía anteriormente con un jardín-paraíso ${ }^{161}$ de la secta de la Tierra Pura, pero fue destruido a principios del siglo XIV y se le encargó a Soseki su reconstrucción como templo zen.

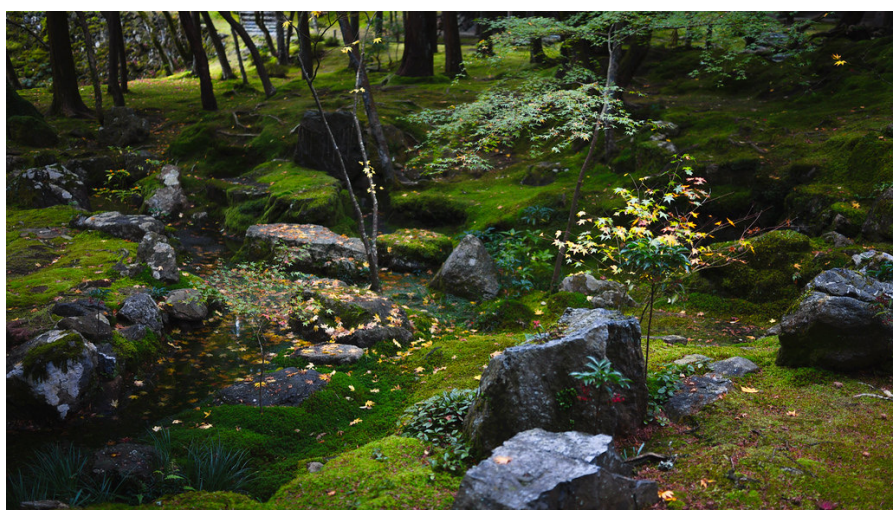

Imagen 35. Vista de Saiho-ji ${ }^{162}$

En realidad, el jardín consta de «dos zonas de atmósfera muy diferente: la baja con un lago y la alta donde domina una gran composición de rocas» ${ }^{163}$. La zona baja se corresponde con el antiguo jardín-paraíso, cuyo estanque Soseki agranda construyendo un embarcadero y además un sendero que lo recorre, convirtiéndolo en un jardín de paseo ${ }^{164}$, género que después se hará popular en el siglo XVII y cuyo ejemplo más representativo será la villa imperial de Katsura. Esta zona está completamente cubierta por el musgo que le da diferentes tonalidades de verde al conjunto y le otorga una cualidad de «espacio encantado» ${ }^{165}$.

${ }^{160}$ Cabañas, «Un puente ...», 244.

${ }^{161}$ Durante la era Heian (794-1185) la secta budista Jodo-kyo (Escuela de la Tierra Pura) representaba el Paraíso a través de jardines alrededor de los edificios y seguía «literalmente los dibujos y descripciones escritas de la Tierra Pura, en los que se representa al Buda Amida en el centro de un edificio con estilo de palacio y frente a un jardín con estanque». Carmen Gracia, «La Tierra Pura, el fin del Dharma y la mirada al paisaje: Una introducción a los orígenes del jardín japonés», Saitabi. Revista de la Facultad de Geografía e Historia 57 (2007): 127.

162 [cipher]. «Saiho-ji temple». Flickr.com. 19 de noviembre de 2015. https://www.flickr.com/photos/ $\underline{\mathrm{h} 4 \mathrm{ck} / 23182107986 / .}$

${ }^{163}$ Vives, Historia y arte..., 59.

${ }^{164}$ Estos jardines no estaban diseñados para ser vistos desde un solo punto fijo concreto, sino para andar a través de ellos y así «el paisaje iba cambiando constantemente a medida que se avanzaba por él». Terao, «El jardín japonés...», 237.

${ }^{165}$ Vives, Historia y arte..., 60. 
M. ${ }^{a}$ DOLORES ROMERO ORTIZ. EL JARDÍN JAPONÉS EN SIX...

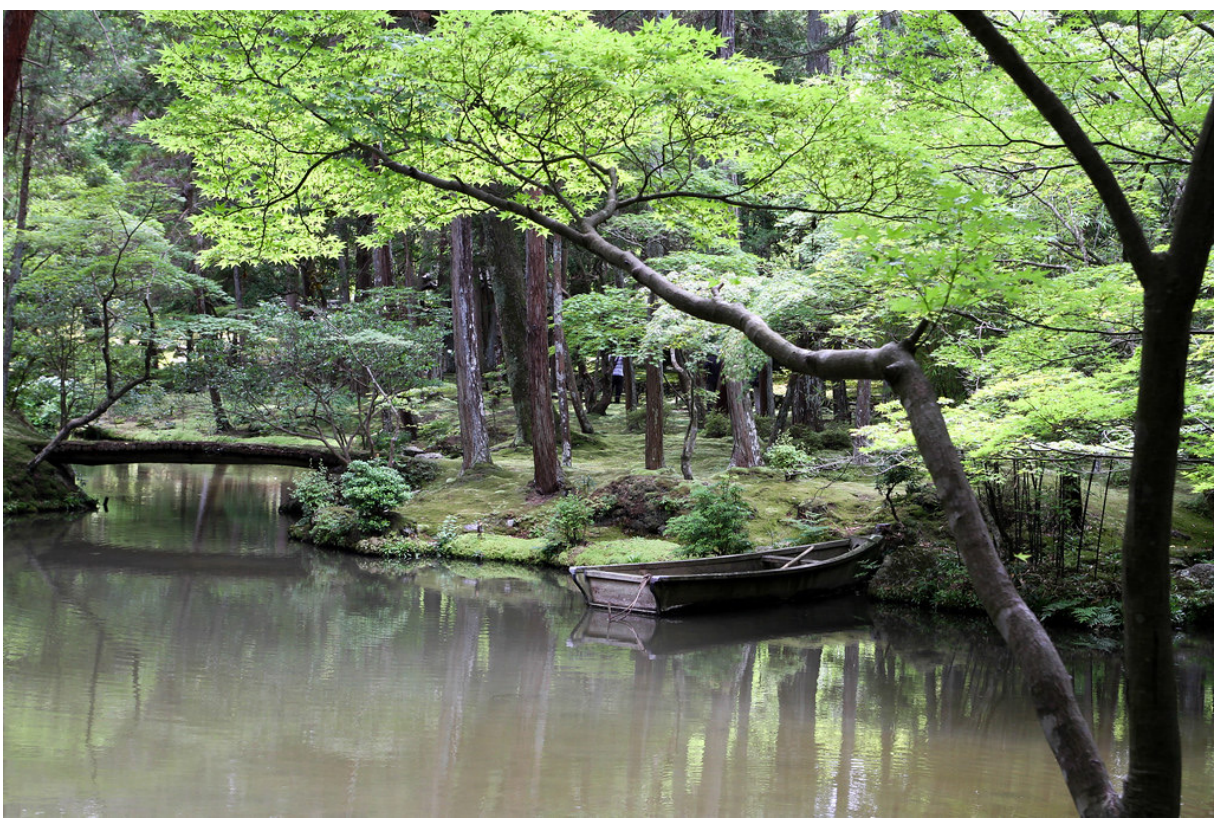

Imagen 36. Embarcadero de la zona baja de Saibo-ji $i^{166}$

Los árboles filtran la luz dejando pasar solo la imprescindible. Las texturas y tonos ondulados del tapiz de musgo varían constantemente; incluso los pequeños puentes, que conducen a las islas, están cubiertos por su esponjoso manto. Su espléndido tono verde alcanza el máximo esplendor a principios de verano inundando todo el ambiente; pero cuando llega el otoño, su relajante color acoge con gusto el rojizo contrapunto de unos pocos arces, proporcionando un auténtico placer visual al caminante. Semejante entorno, ayudado por el eco del silencio y los dorados rayos de sol, se transfigura imperceptiblemente convirtiéndose en un espacio encantado ${ }^{167}$.

\footnotetext{
${ }^{166}$ Eric T. «In Saiho-ji». Flickr.com. 26 de julio de 2013. https://www.flickr.com/photos/ericts/9371229593/.

${ }^{167}$ Vives, Historia y arte..., 60.
} 
M. ${ }^{a}$ DOLORES ROMERO ORTIZ. EL JARDÍN JAPONÉS EN SIX...



Imagen 37. Zona baja de Saiho-ji en otoño ${ }^{168}$

Al norte del estanque, una puerta permite el acceso a la zona alta del jardín tras subir una escalera de piedras; allí, aprovechando la pendiente del terreno, se ha colocado un conjunto de rocas (cubiertas de liquen) que asemeja a una cascada de casi 20 metros sin ninguna presencia real de agua. En realidad, las rocas se agrupan en dos conjuntos denominados La isla de la tortuga (por tener dicha apariencia) y Cascada pétrea ${ }^{169}$ respectivamente. Además, como indica Cabañas: «todas están dispuestas para que el campo visual se estreche de abajo hacia arriba y produzca un efecto de mayor profundidad ${ }^{170}$.

${ }^{168}$ Annie Guilloret. «Kyoto Kokodera Saiho-ji Temple de mousses». Flickr.com. Diciembre de 2013. https:// www.flickr.com/photos/nahemaparis/21723315679/.

${ }^{169}$ Vives, Historia y arte..., 61.

${ }^{170}$ Cabañas, «Un puente...», 244-245. 


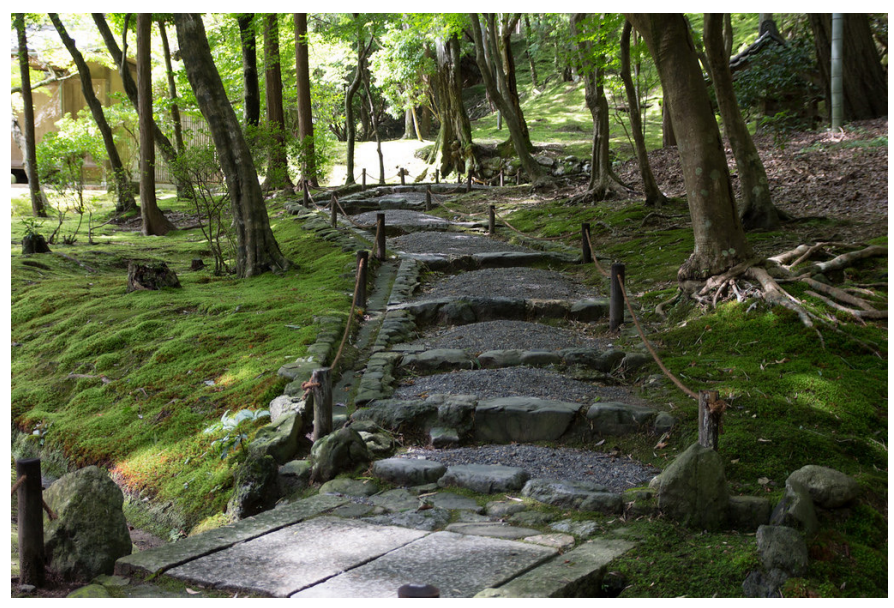

Imagen 38. Escalera de piedras para acceder a la zona alta de Saiho-ji ${ }^{171}$

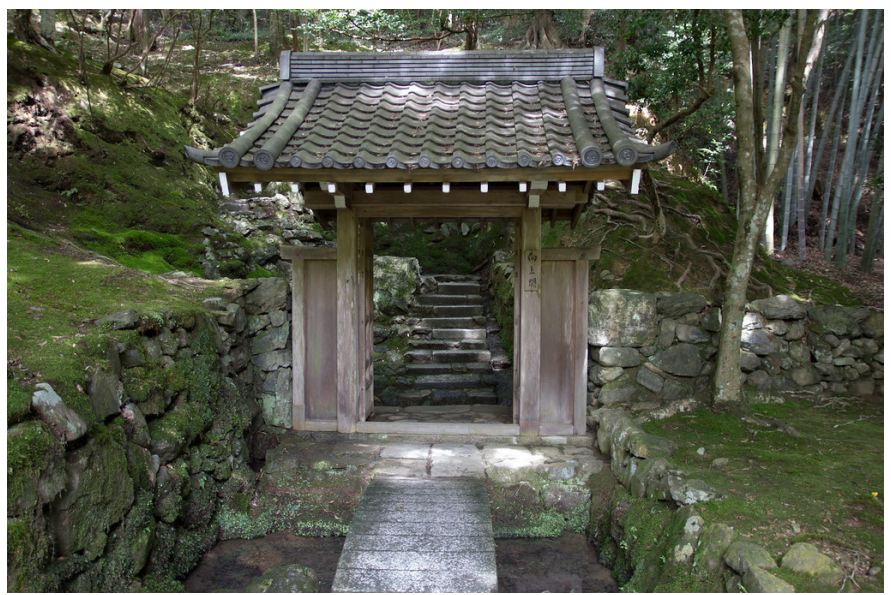

Imagen 39. Puerta de acceso a la zona alta de Saiho-ji $i^{172}$

${ }^{171}$ Christian Kaden. «Kokedera - the Temple of Moss». Flickr.com. 10 de septiembre de 2012. https://www. flickr.com/photos/satorinihon/8015672117/.

${ }^{172}$ Christian Kaden. «Kokedera - the Temple of Moss». Flickr.com. 10 de septiembre de 2012. https://www. flickr.com/photos/satorinihon/8015679032/. 


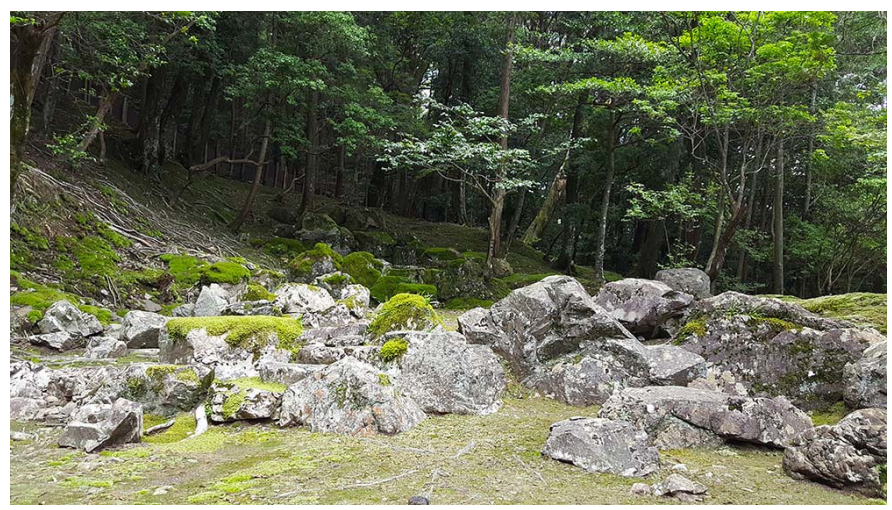

Imagen 40. Cascada de piedra de la zona alta de Saibo-ji ${ }^{173}$

III.1.5.1. La pieza

Tabla 12. Generalidad de la pieza V

\begin{tabular}{|l|l|}
\hline Pieza & V. Moss garden of the Saibo-ji \\
\hline Duración & $02: 47$ \\
Instrumentación & Crótalos, triángulo y pandereta \\
& Madera, metal y piedra \\
& Electrónica \\
Tempo/Carácter & Espressivo
\end{tabular}

En primer lugar, los dos ambientes claramente diferenciados de Saiho-ji aparecen reflejados en la instrumentación y en el material asociado a cada conjunto percusivo: por un lado, tenemos los crótalos junto al triángulo y la pandereta —en un diseño de cinquillos casi perenne que se diluye al final - y por otro el conjunto de madera, metal y piedra (tres instrumentos a elección del intérprete dentro de las familias indicadas) — que comienzan con un diseño de corcheas que acelerará hasta el seisillo de semicorcheas-. La diferenciación de ambientes también se produce gracias a la afinación de los crótalos, resultando así un conjunto de altura determinada en contraposición al trío de madera, metal y piedra (conjunto de altura indeterminada).

${ }^{173}$ Mihoyo Fuji. «Saihoji kokedera karesansui2». Flickr.com. 11 de julio, 2017. https://www.flickr.com/ photos/157604126@N05/36514366805/ 


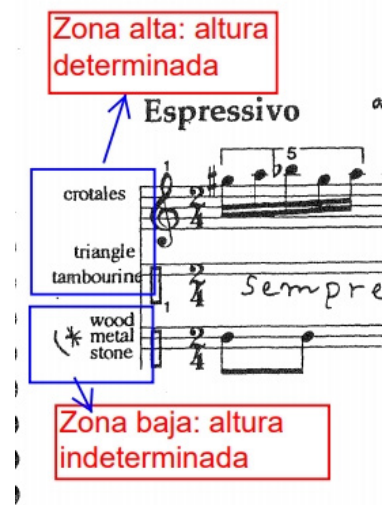

Imagen 41. Contraposición de grupos percusivos en la pieza V

La zona alta está representada por los crótalos, triángulo y pandereta. La nota la se sitúa como centro de la composición a semejanza del motivo central en los jardines japoneses.

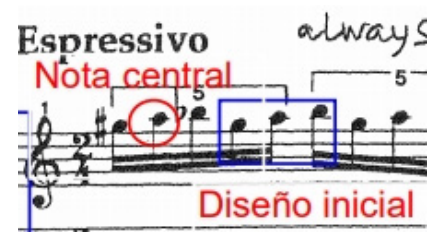

Imagen 42. Pentagrama superior: nota central y diseño inicial (pieza V)

Como se ha indicado más arriba, las piedras en cascada se disponen de tal manera que se produzca un estrechamiento al elevar la mirada o viceversa; así, esta parte comienza en el agudo, con los crótalos en un diseño de semitonos (sol\#-la-sib) que, a partir del compás 3, se verá interrumpido por la pandereta y el triángulo en determinados puntos. En este momento, comienzan dos procesos diferentes: el primero de ellos, un descenso, en alegoría de la cascada que desciende; mientras el la permanece constante en el agudo, el si bemol desaparece, y el resto de alturas comienzan un suave descenso (tomando como referencia la nota inicial de cada grupo) en forma semejante a pequeñas plataformas (ver imagen 43) hasta el compás 11: fa\#-sol (2 veces), re\#-mi (2 veces), do\#, do\#-re, sido, si, si-do, sol\#, sol-lab, fa\#-sol, fa-solb, fa. 


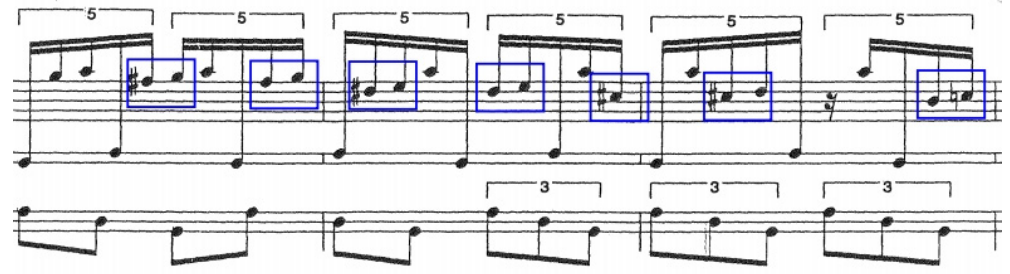

Imagen 43. Fragmento (compases 4 a 6) del descenso en plataformas (pieza V)

El segundo proceso es un vaciado que comienza con el silencio de semicorchea del compás 6 y que, mediante el alargamiento de figuras, irá creando el vacío entre el la del crótalo y el golpe de pandereta, tal como si el oyente abarcara de un vistazo la totalidad de la cascada de piedra, hasta fijarse en un ritmo constante de corcheas.

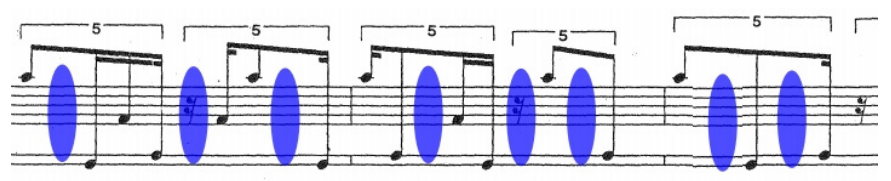

Imagen 44. Fragmento del proceso de vaciado (compases 11 a 13) en la pieza $\mathrm{V}$

Es de destacar que en el grupo la pandereta sea el único instrumento no metálico, lo que hace despuntar su sonoridad más mate, en referencia al musgo por el que es famoso el jardín.

La zona baja simboliza mediante la instrumentación los elementos del jardín: la madera de los pabellones y el embarcadero, el metal del estanque y la piedra de los caminos. La línea de estos instrumentos sufre una aceleración contraria a la del conjunto superior, comenzando en corcheas que acelerarán progresivamente a tresillos de corcheas, semicorcheas y seisillos de semicorcheas (que a su vez sufrirá un proceso de aceleración mediante su figuración interna), como se aprecia en la reducción de la imagen 45. Esta presencia de carácter más constante evoca los pasos del caminante que deambula por los senderos del jardín inferior. 
El conjunto sonoro, gracias a la polirritmia y la polimétrica ${ }^{174}$, crea una sensación auditiva que remite al ruido del agua, a gotas que golpean diferentes superficies, con una técnica que se relaciona automáticamente a la estocástica ${ }^{175}$ de Xenakis.

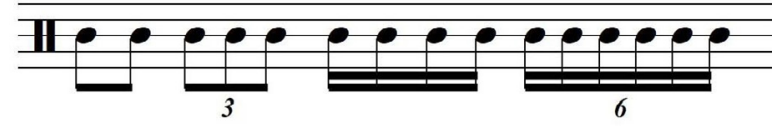

Imagen 45. Reducción del proceso de aceleración en el pentagrama inferior de la pieza $\mathrm{V}$

Por último, se debe aludir a la perseverancia sonora del instrumental que, junto a la electrónica, nos remite al proceso de reiteración como medio para lograr la meditación.

Tabla 13. Asociaciones instrumentales en la pieza $\mathrm{V}$

$\begin{array}{cccccc}\text { Zonas } & \text { Componentes } & \text { Instrumentos } & \text { Elementos } & \text { Color } & \text { Simbología } \\ \text { Alta } & \text { Piedras } & \begin{array}{c}\text { Crótalos y } \\ \text { triángulo }\end{array} & \text { Metal-agua } & \begin{array}{c}\text { Gris (blanco y } \\ \text { negro) }\end{array} & \text { Lo inmaterial } \\ & \text { Musgo } & \text { Pandereta } & \text { Tierra } & \text { Amarillo } & \begin{array}{c}\text { Mediador entre el } \\ \text { cielo y la tierra }\end{array} \\ & \text { Embarcadero } & \text { Madera } & \text { Madera } & \text { Verde } & \text { La materia } \\ \text { Baja } & \text { Agua-estanque } & \text { Metal } & \text { Metal-agua } & \begin{array}{c}\text { Blanco y } \\ \text { negro }\end{array} & \text { Origen de la vida } \\ & \text { Caminos } & \text { Piedra } & \text { Tierra } & \text { Amarillo } & \text { Asociada al alma }\end{array}$

Con respecto a la simbología de la elección instrumental, es significativa la división entre las zonas alta y baja. La zona alta, en la que se determinan los instrumentos a emplear, utiliza asociaciones ya explotadas anteriormente: instrumentos de metal como agua (lo inmaterial, lo espiritual) y la pandereta como la tierra (mediador entre lo celeste y lo terreno); en cambio, la zona baja parece contextualizar al hombre, lo matérico. Siguiendo a Chevalier ${ }^{176}$, la madera es símbolo de la materia y la piedra aparece en estrecha relación con el alma humana; si a esto aunamos el agua como origen de la

${ }^{174}$ La polimetría es la superposición de esquemas métricos de acentuaciones diferentes, como al inicio de la pieza donde la acentuación del motivo inicial (sol\#-la-sib) en los crótalos se superpone a la acentuación del grupo percusivo inferior.

${ }^{175}$ La música estocástica es aquella que, entre otras técnicas, emplea las leyes de probabilidad matemática para recrear fenómenos naturales como la lluvia. En este caso, no se han utilizado leyes matemáticas, pero la distribución de los puntos de sonido genera una sensación auditiva semejante.

${ }^{176}$ Chevalier, Diccionario..., 673 y 827. 
vida, queda claro que este conjunto instrumental se opone simbólicamente al superior: su indefinición frente a la determinación, la no-altura frente a la altura.

\section{III.1.6. Stone Bridges}

Esta última pieza que cierra la obra recrea Daisen-in, el jardín karesansui de un templo budista zen de Kioto construido en el siglo XvI, solo algunos años después de Ryōan-ji ${ }^{177}$. La peculiaridad de este jardín es que en realidad son cuatro escenas, cada una de ellas en las respectivas cuatro fachadas de la residencia del abad, y que «puede interpretarse como una sola narración continua, semejante a una pintura en rollo» ${ }^{178}$.

Esta narración comienza en un espacio en forma de L entre los patios de la fachada norte y la fachada este: aquí se asiste al nacimiento de un río seco que se bifurcará en dos. Un grupo de grandes rocas simboliza los barrancos por los que cae el agua (encarnada en unas simples vetas blancas en las rocas); la gravilla representa el agua del torrente sobre el que una gran roca hace las veces de puente ${ }^{179}$; la bifurcación hacia el oeste y el sur se escenifica mediante arena rastrillada.

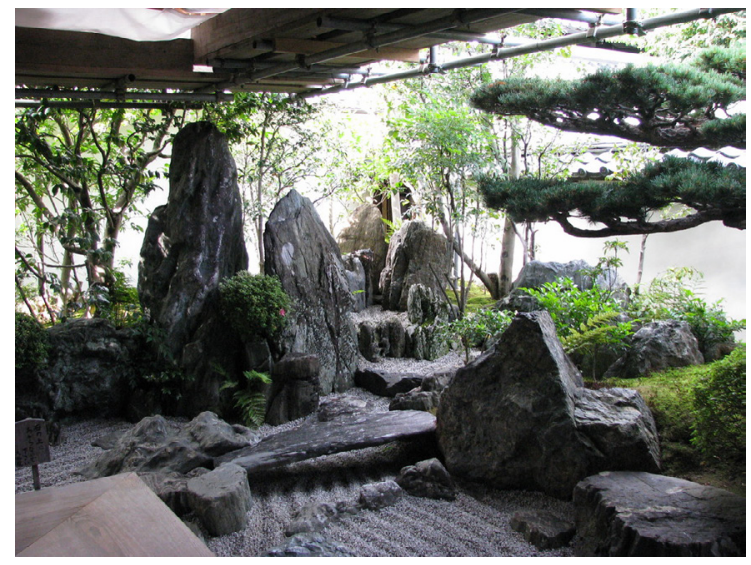

Imagen 46. Nacimiento del río en Daisen-in ${ }^{180}$

Avanzando hacia el oeste, la fachada norte comienza con un grupo de piedras y gravilla de formas variadas que, tras pasar por debajo de una galería que divide el patio en dos, se ensancha

${ }^{177}$ Fariello, La arquitectura..., 293.

${ }^{178}$ Vives, Historia y arte..., 84.

${ }^{179}$ Vives, Historia y arte..., 85.

${ }^{180}$ Wilson Loo Kok Wee. «Kyoto. Daisen-in». Flickr.com. 29 de junio de 2008. https://www.flickr.com/ photos/kwloo/3788055824/. 
transformándose en «un tranquilo lago seco» ${ }^{181}$ con una camelia (que simboliza el monte Hōrai) y dos grupos de dos y tres rocas respectivamente.

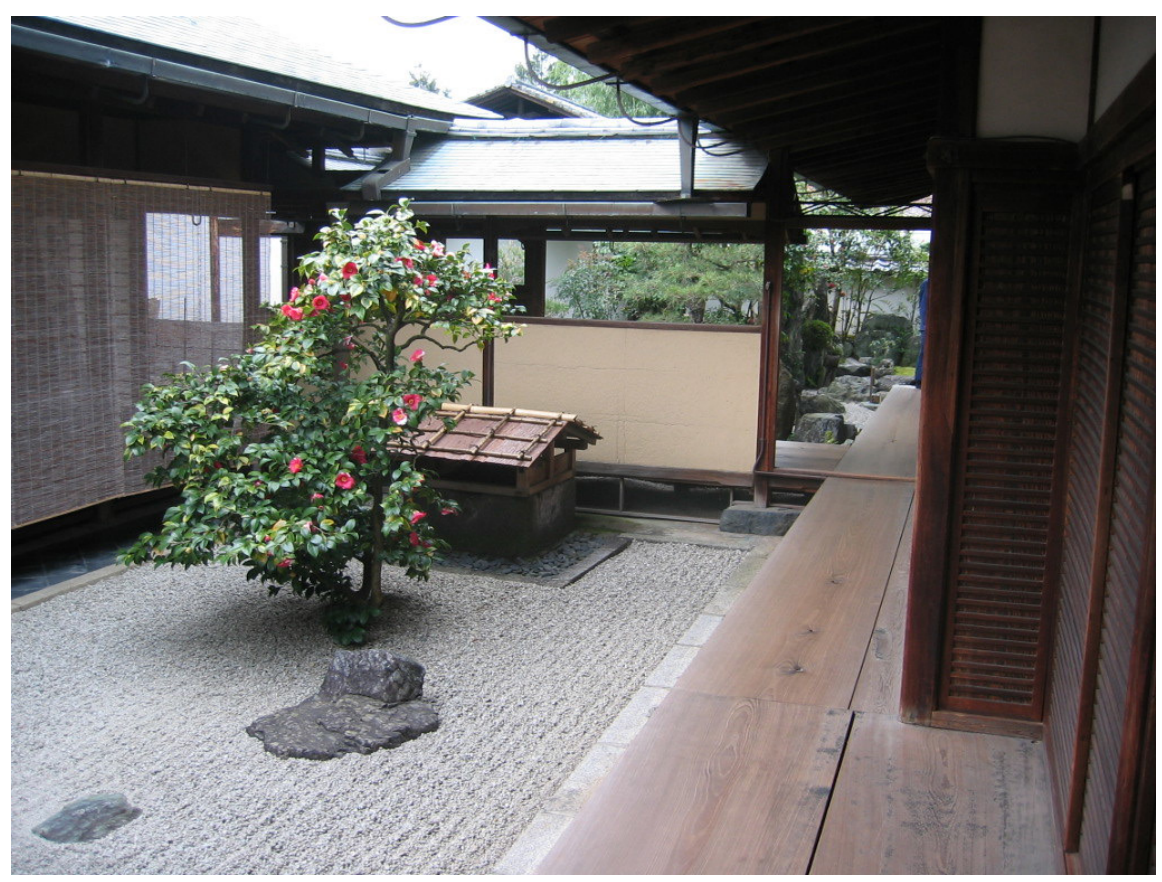

Imagen 47. Lago seco con camelia en Daisen-in ${ }^{182}$

Retrocediendo al nacimiento del río y continuando en dirección sur, se encuentra el patio de la fachada este. En el río de gravilla, algunas rocas se sitúan representando una tortuga y una grulla (símbolos de longevidad). Tras un pequeño salto, como ocurriera en la fachada norte, el río se ensancha y aparece una gran roca con forma de barcaza ${ }^{183}$.

${ }^{181}$ Vives, Historia y arte..., 85.

182 tiarescott. «Japan-Kyoto-Daitoku-ji-zen-buddhist-temple-Daisen-in-Japan-Inland-Sea-April-2004». Flickr. com. 2 de abril de 2004. https://www.flickr.com/photos/tiarescott/33507966.

${ }^{183}$ Vives, Historia y arte..., 86. 
M. ${ }^{a}$ DOLORES ROMERO ORTIZ. EL JARDÍN JAPONÉS EN SIX...

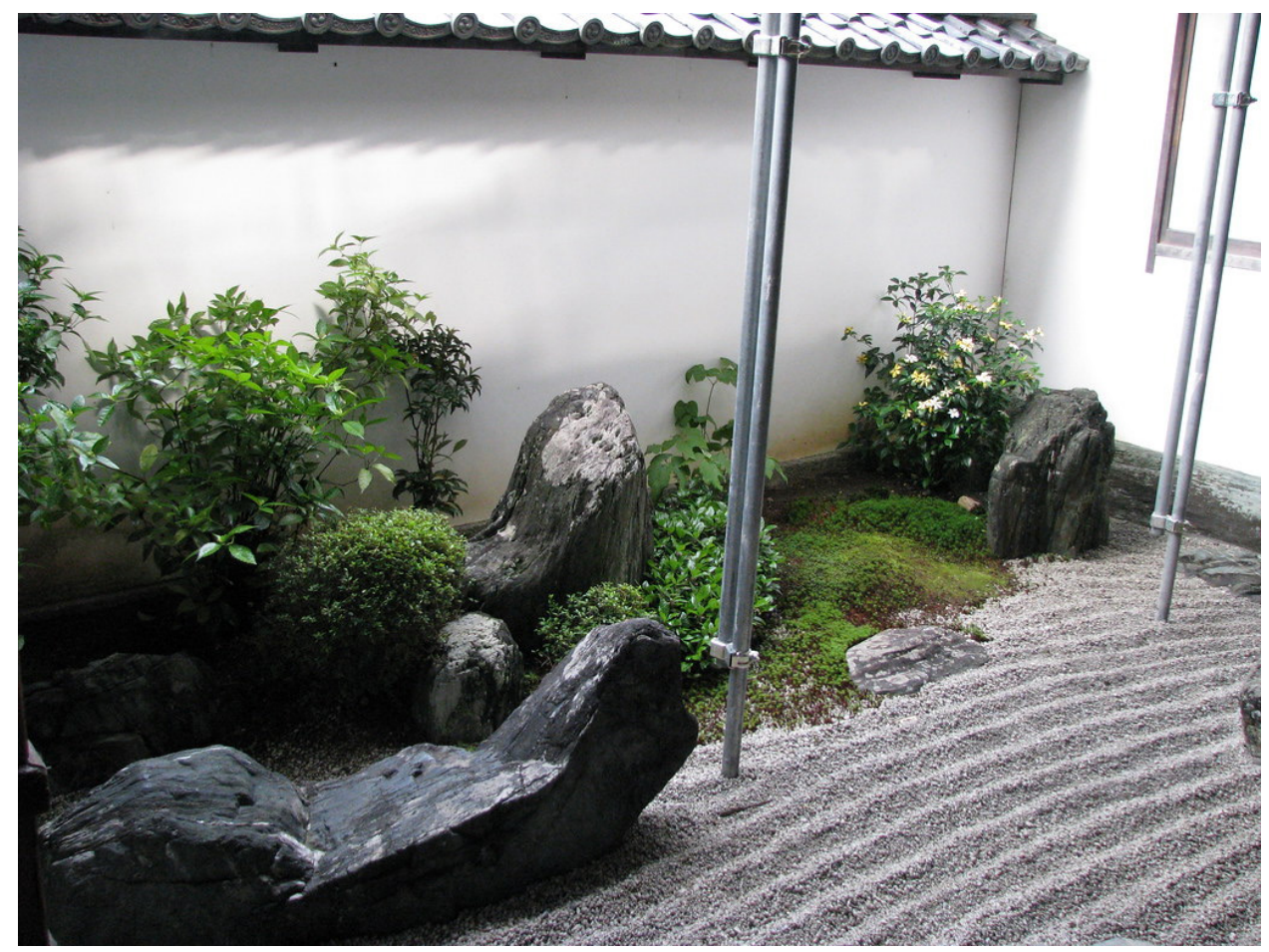

Imagen 48. Roca en forma de barcaza en Daisen-in ${ }^{184}$

Esta parte acaba tal como si desembocara en el mar en la fachada sur, cuya «superficie está cubierta de un impoluto lecho de gravilla rastrillada en ondas paralelas» ${ }^{185}$. En esta superficie aparecen dos conos de piedra que «son levantados para que la divinidad se pose cuando viene a visitar el templo» ${ }^{186}$.

La fachada oeste es un área vacía.

${ }^{184}$ Wilson Loo Kok Wee. «Kyoto. Daisen-in». Flickr.com. 29 de junio de 2008. https://www.flickr.com/ photos/kwloo/3788059402/.

${ }^{185}$ Vives, Historia y arte..., 88 .

${ }^{186}$ Cabañas, «Un puente...», 247. 


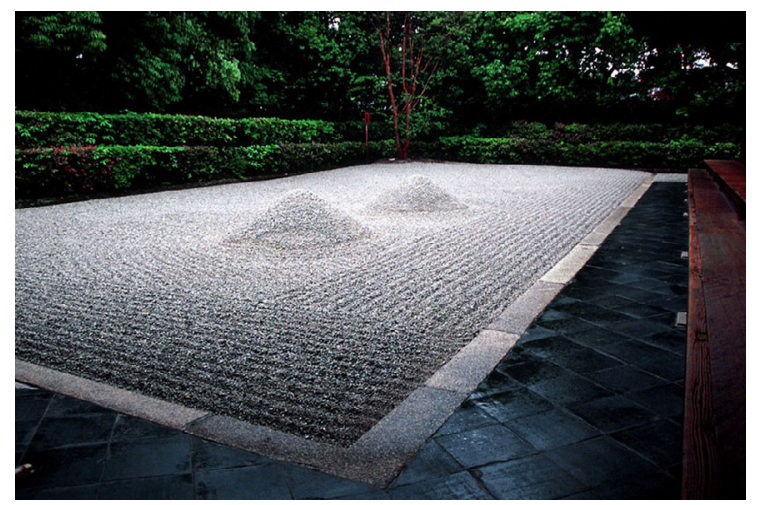

Imagen 49. Conos en la fachada sur en Daisen-in ${ }^{187}$

III.1.6.1. La pieza

Tabla 14. Generalidad de la pieza VI

\begin{tabular}{ll}
\hline Pieza & VI. Stone bridges \\
\hline Duración & $03: 18$ \\
Instrumentación & Placa de metal y caja china \\
& Tambor de hendidura, tambor chino y triángulo \\
& Gongs (2), pandereta y plato suspendido \\
& Timbales y crótalos \\
& Electrónica \\
Tempo/Carácter & Furioso
\end{tabular}

Tal como enuncia el título de la pieza, esta composición se inspira en la idea de puentes tendidos entre diversas escenas. Stone Bridges se divide en seis paisajes, cada uno de los cuales (a excepción del primero) deriva del material anterior (ver imagen 50) tras la interrupción de un golpe en sfź, el cual fluctúa tímbricamente cada vez entre diversos instrumentos (tambor de hendidura, gong, tambor de hendidura, tambor chino y crótalo) junto al punto de inicio de las frases de la electrónica; de esta forma, se encarna musicalmente la importancia de los puentes pétreos como elementos separadores contrastantes que «interrumpen» el flujo de la corriente acuática (continuo percusivo), que retoma su curso tras «pasan» por debajo del puente o galería.

${ }^{187}$ Brad Micklea. «Daisen-in_Zen_Garden». Flickr.com. 1 de noviembre de 2014. https://www.flickr.com/ photos/bradmicklea/15659472876/. 


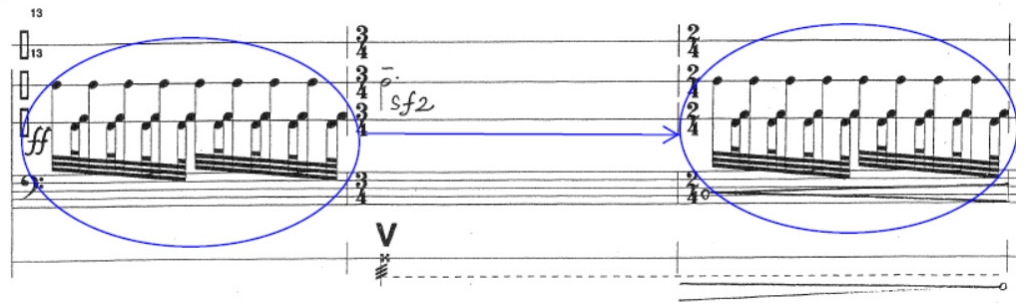

Imagen 50. Ejemplo de continuación del material (compases 13 a 15) de la pieza VI

Cada uno de los puentes aparece representado por diversos instrumentos: el primero de ellos en el compás 14 con el tambor de hendidura es el puente inicial, el situado en el origen del agua en la L formada entre los patios norte y este; el segundo puente inaugura la entrada en el patio norte en el compás 24 con el gong; la música continúa atravesando la galería que divide dicha escena (tambor de hendidura, compás 32). La entrada en el patio este comienza con el ataque en sfź de tambor chino - en el compás 44 al que sigue el continuo percusivo, el cual tras superar un breve salto (nuevamente con el tambor chino pero esta vez en poco sfźp para distinguirlo de los puentes en el compás 54), avanza hasta «desembocar» en el gran mar en la fachada sur con el crótalo en el compás 61.

A continuación se expone un esquema de la pieza:

Tabla 15. Esquema comparativo estructural de la pieza VI

\begin{tabular}{|c|c|c|}
\hline \multirow{3}{*}{$\begin{array}{l}\text { Esquina en } L \\
\quad \text { (cc. 1-23) }\end{array}$} & Nacimiento del agua & Continuo percusivo \\
\hline & Puente de piedra & Sfz Tambor de hendidura \\
\hline & Flujo de agua (arena rastrillada) & Continuo percusivo \\
\hline \multirow{4}{*}{$\begin{array}{l}\text { Patio norte } \\
\text { (cc. 24-43) }\end{array}$} & Puente de piedra & Sfž Gong \\
\hline & Flujo de agua (piedras variadas) & Continuo percusivo \\
\hline & Galería & Sfz Tambor de hendidura \\
\hline & Río seco y camelia & Continuo percusivo \\
\hline \multirow{4}{*}{$\begin{array}{l}\text { Patio este } \\
\text { (cc. 44-60) }\end{array}$} & Puente de piedra & Sfz Tambor chino \\
\hline & Flujo de agua (arena y rocas) & Continuo percusivo \\
\hline & Salto & Poco sfž Tambor chino \\
\hline & Barcaza & Continuo percusivo \\
\hline \multirow{3}{*}{$\begin{array}{l}\text { Patio sur } \\
\text { (cc. 61-70) }\end{array}$} & Puente de piedra & Mf Crótalo (afinado) \\
\hline & Mar & Continuo metálico \\
\hline & Dos conos & Dos golpes de triángulo \\
\hline
\end{tabular}




\section{III.1.6.1.1. Esquina en L (compases 1-23)}

El punto de inicio está marcado por el nacimiento del agua. En la pieza, la música «nace» de un redoble de timbal que crece desde al niente en el compás 2 hasta el fortissimo en el compás 4 . Poco a poco este material se deslizará, en alusión a la cascada representada en las vetas blancas de las rocas, mediante sutiles glissandi de un sol bemol hacia un la, y desde el fa más grave hacia el sol, trasladando así el clúster del timbal fa-sol-sib hasta sol-la-sib; todo ello en figuras ascendentes en duodecillos (ver imagen 51) que a partir del compás 8 continúan deslizándose hacia los instrumentos no afinados: el sol del timbal se desliza hacia los gongs (primero uno y luego ambos alternos) y el la hacia el tambor de hendidura (compás 10). El timbal decrece en dinámica rápidamente (mientras gongs y tambor crecen hasta el ff) hasta que finalmente desaparece en el compás 13.

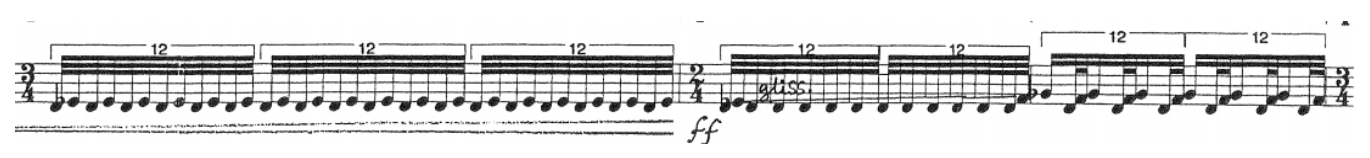

Imagen 51. Timbales en los compases 3-5 de la pieza VI

El primer puente de piedra irrumpe en el compás 14 con el tambor de hendidura y la electrónica; al compás siguiente, el continuo percusivo retoma la figura anterior y prosigue su evolución en crescendo (como el arroyo de arena rastrillada) incluyendo la placa de metal que sustituye al tambor de hendidura en ciertos puntos (compases 18, 20, 21 y 22). El continuo se cierra en el compás 23 en una rápida alternancia entre los dos gongs para dirigir al oyente hacia el patio norte.

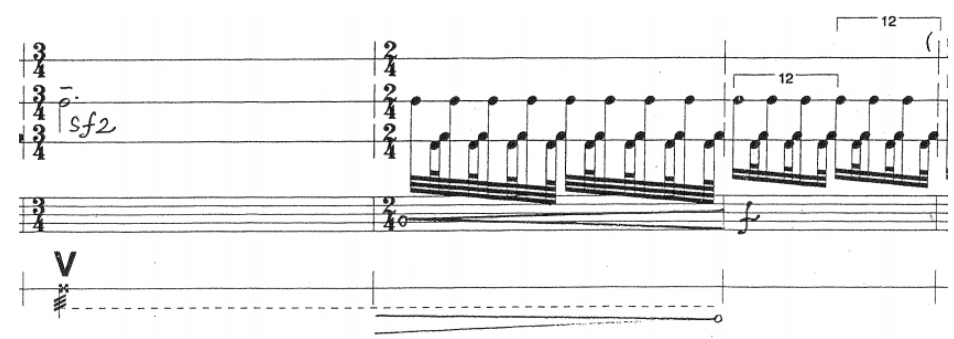

Imagen 52. Inicio del primer puente de piedra en la pieza VI (compases 14 a 16)

III.1.6.1.2. Patio norte (compases 24-43)

Un nuevo puente de piedra (sfz del gong) abre el viaje por el patio norte. El continuo (que retoma la figura del compás 23), algo más tranquilo ahora (la dinámica solo crece hasta el $m f$ y la figuración se ralentiza), se transforma al desaparecer los gongs en el compás 27. A partir de este 
momento, el tambor de hendidura y la placa de metal se alternan hasta que, en el compás 30, la pandereta se une al conjunto en crescendo hasta la interrupción de la galería (compás 32, sfź del tambor de hendidura). Un continuo percusivo plano en dinámica (en ff) simboliza el río seco con la camelia: lo inician la placa de metal y la pandereta a las que se añade en el compás 34 el tambor chino; este finalmente desaparece para dejar su sitio a la caja china en el compás 43.

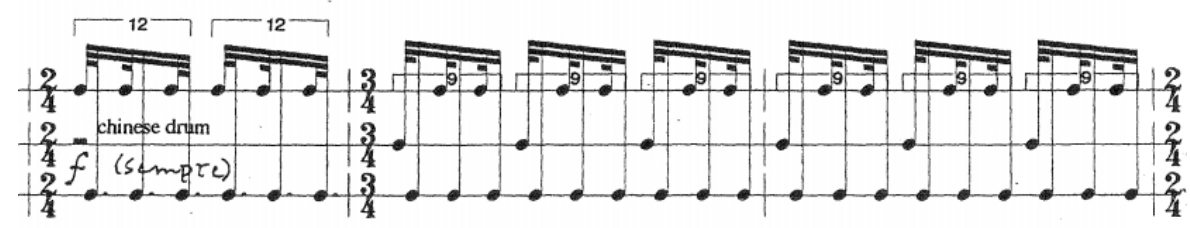

Imagen 53. Continuo percusivo de placa de metal, pandereta y tambor chino entre los compases 33 y 35 en la pieza VI

\section{III.1.6.1.3. Patio este (compases 44-60)}

El patio este comienza con un diferente puente de piedra: en el sfz del tambor chino en el compás 44. Al igual que ocurriera más atrás, este patio presenta un continuo relativamente estable (la dinámica se mantiene en $f$ sempre hasta el diminuendo que preludia la entrada de los crótalos); se retoma la figura del compás 43 , en la que desaparece la pandereta en el compás 47 para ceder su sitio al plato suspendido (primer paso hacia la sonoridad de metal del patio sur) en el compás 49. A continuación, la caja china se evapora y los crótalos irrumpen brevemente en el compás 53, preparando el salto de agua en el compás 54 con el tambor chino en sfź; la barcaza de piedra se desliza desde el compás 55 hasta el compás 60 en crescendo-decrescendo, donde el tambor chino desaparece en favor del plato suspendido y los crótalos, a distancia de segunda menor.

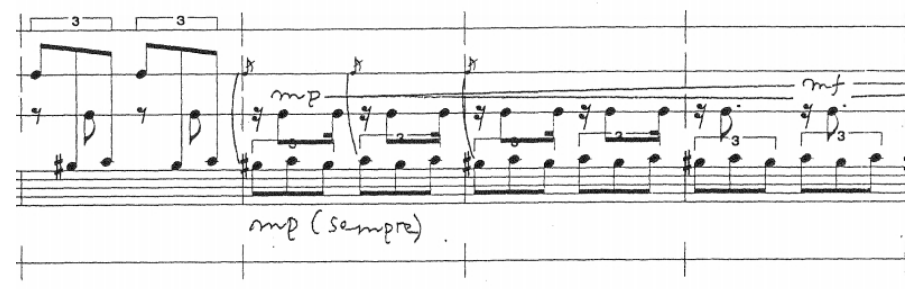




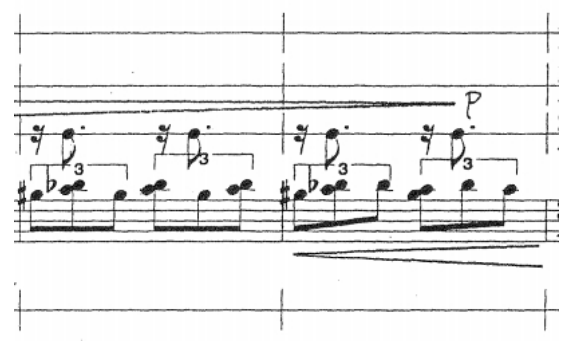

Imagen 54. Compases 55 a 60 de la pieza VI

III.1.6.1.4. Patio sur (compases 61-70)

Tabla 16. Evolución instrumental de la pieza VI

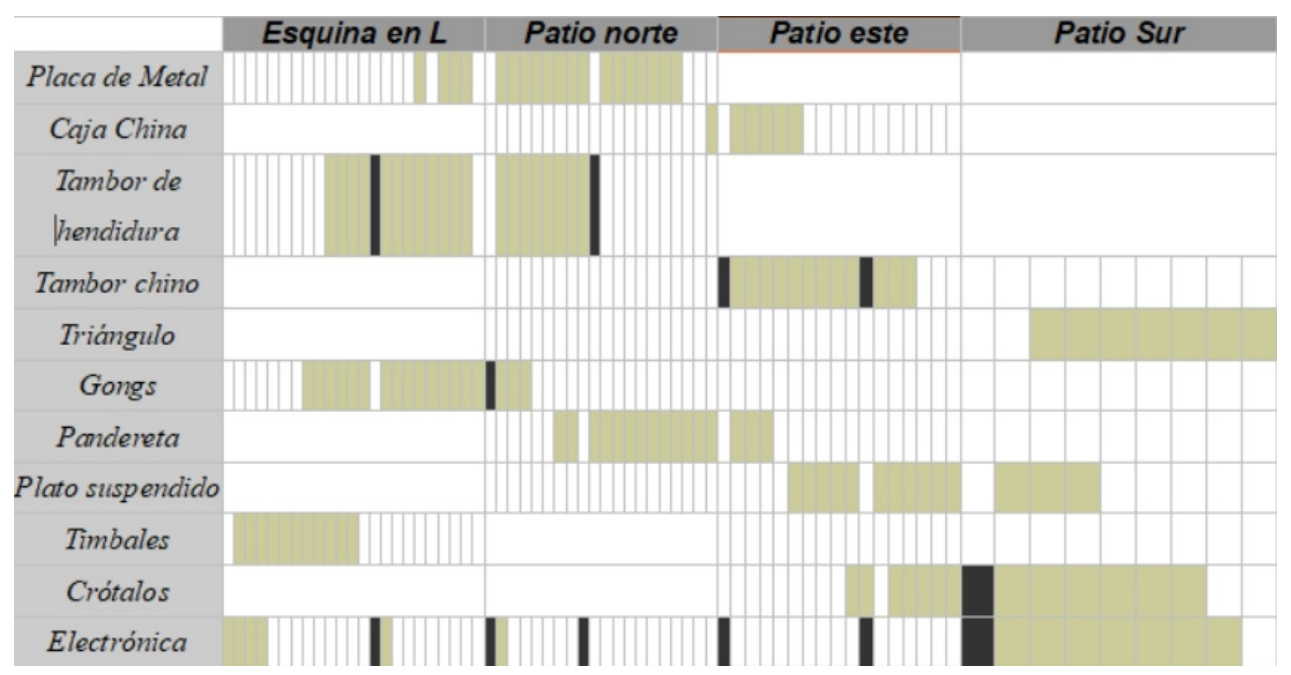

Finalmente, la pieza se diluye en el gran mar con el sonido metálico de crótalos, plato suspendido y triángulo. El plato suspendido se ralentiza hasta desaparecer mientras que los crótalos experimentan una evaporación progresiva. La obra acaba con golpes de triángulo regulares, los dos últimos — que representan los dos conos de piedra del jardín - en bucle hasta desaparecer al niente; la electrónica acompaña continuamente a los sfz y se mantiene durante unos compases hasta que finalmente también finaliza al niente. 


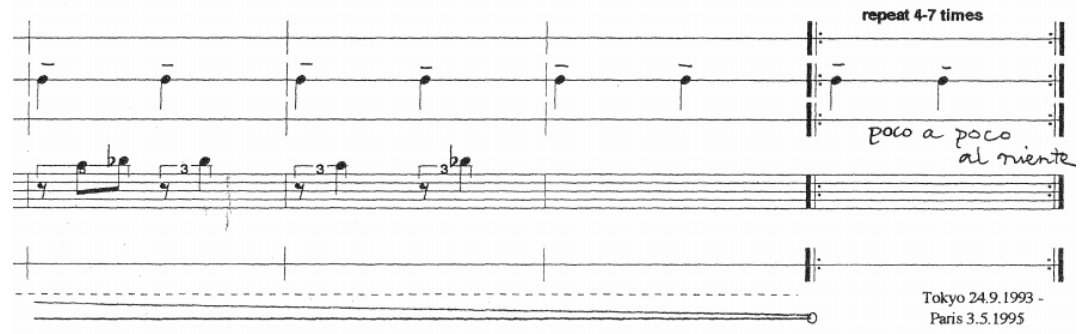

Imagen 55. Compases finales de la pieza 6

Toda la pieza es una gran sonoridad continua, furiosa, como el agua que se precipita (los cambios instrumentales se exponen visualmente en la tabla precedente), siempre cambiante mediante sutiles entradas y salidas de instrumentos del continuo, que se interrumpe con los sfz-los puentes de piedra del título - para continuar seguidamente en el punto donde lo dejó, hasta finalmente desembocar en el mar, representado en el sonido del metal. Triángulo, plato suspendido y crótalos, como puede verse en la tabla 17 , encarnan la vuelta a lo inmaterial: la obra se cierra centrándose en lo espiritual.

Tabla 17. Asociaciones instrumentales del final de la pieza VI

$\begin{array}{ccccc}\text { Componentes } & \text { Instrumentos } & \text { Elementos } & \text { Color } & \text { Simbología } \\ \text { Piedrasy Arena } & \text { Triángulo, plato } & \text { Metal (agua) } & \text { Gris (blanco y } & \text { Lo inmaterial } \\ & \text { suspendido y crótalos } & & \text { negro) } & \end{array}$

\section{Conclusiones}

El presente trabajo de investigación partía de una pregunta: ¿cómo se materializa el concepto de jardín japonés, sus principios y elementos, en la obra Six Japanese Gardens de la compositora Kaija Saariaho?

Tras llevar a cabo la lectura bibliográfica y la aplicación de los diferentes análisis a las piezas integrantes de la obra, es posible afirmar que los elementos y principios que caracterizan el objeto artístico conocido como jardín japonés tienen una traducción musical en la composición de la autora finlandesa. En este apartado conclusivo, se determina a continuación cómo se concretan el concepto y principios del jardín japonés así como sus fundamentos estéticos y simbólicos; al mismo tiempo, se ofrece cómo dichos principios artísticos afectan al trabajo técnico compositivo. 
Como se comentó al inicio de esta investigación, el jardín japonés es un microcosmos, una representación simbólica que nace a partir del concepto de mitate, de metáfora, como vía espiritual para alcanzar la iluminación en un marco fuertemente influenciado por el budismo zen; las seis piezas integrantes de la obra de Saariaho son a su vez un fiel reflejo de esta idea: cada una de ellas es la representación de un jardín concreto, el cual es interpretado musicalmente a través de analogías simbólicas que se vierten bien en determinados tratamientos paramétricos, trabajo técnico compositivo o en elecciones musicales.

En primer lugar, el carácter casi ritual de las piezas responde a la búsqueda de la concentración para la meditación: el tratamiento de los materiales musicales se imbrica en una sonoridad continua donde la repetición no literal, sino evolutiva, es un principio generador; los pulsos son percutidos, incluso en aquellas secciones basadas en la polirritmia, en la búsqueda de esa sonoridad general que si bien es constante en su percepción — a macronivel — cambia continuamente de manera interna —a micronivel - bien por el tratamiento del material (como en la segunda pieza) o por el propio timbre instrumental (recuérdense los cambios instrumentales descritos en la última pieza).

Los principios de sencillez y abstracción también recorren el armazón de la obra; los materiales empleados en todo momento son extraordinariamente sencillos: iteraciones cambiantes en figuraciones más o menos constantes, sin complejidad rítmica o textural. Además la obra no es unívoca en su interpretación, tanto por parte del ejecutante como del oyente. Hay determinados parámetros que quedan a la elección del percusionista como los instrumentos cuando únicamente se indica piedra o metal en las piezas III y V, por ejemplo. Pero también su definición conceptual queda a cargo del oyente: el significado de la combinación tímbrica o la numerología no tiene por qué ser conocido de antemano, la obra es susceptible de ser apreciada sin dicho conocimiento y que el oyente llegue a sus propias conclusiones; es decir, la abstracción conceptual es parte de la obra artística que solo se completa cuando el receptor desprende su significado, el cual no tiene por qué coincidir con la idea original de la autora.

Todo lo anterior se conecta con el vacío, aspecto indisoluble del zen y que como se ha visto fue puesto en valor dentro de la música por autores como John Cage en forma de silencio. El vacío no es evidente en la obra de Saariaho, no hay grandes espacios de silencio dentro del continuum musical; pero sí que se encuentra un fundamento de menos es más, es decir, del empleo de timbres reducidos, materiales generadores limitados y muy pocas alturas definidas, todo ello en un contexto textural con baja densidad (independientemente del hecho físico de contar con un solo intérprete) incluso en la parte electrónica. Aquí entra asimismo la falta de complejidad rítmica y un continuo sonoro que no busca la saturación acústica.

Los principios de dualidad y asimetría se enraízan ya directamente en el carácter simbólico de la música; la unión de contrarios está presente en toda la obra en tres líneas: la dualidad instrumental, 
la unión entre lo temporal y lo espiritual y la unión entre el hombre y la naturaleza. Esta última línea es la que menos se manifiesta en la obra: solo en algunos lugares puntuales como la electrónica en la primera pieza (grillos y voces humanas). La dualidad instrumental y la unión entre lo temporal, o matérico, y lo espiritual, están en cambio presentes constantemente. La dualidad instrumental se manifiesta en la oposición entre instrumentos de altura determinada y de altura indeterminada, como en la pieza dedicada al jardín de Saiho-ji (pieza V), pero esencialmente en la separación según su material de construcción en consonancia con su simbología elemental: metal (como el triángulo o los platos), madera (como la caja china) o parche (como la pandereta o el timbal); la dualidad material/espiritual se inserta en la interpretación simbólica.

Los instrumentos simbolizan tanto elementos del jardín (puentes, piedras, islas, etc.) como los cinco elementos y colores de la filosofía tradicional china: en este sentido es de destacar que la asociación simbólica no se mantiene constante en todas las piezas, sino que hay pequeños cambios debido a la configuración de los propios jardines.

La principal asociación que puede establecerse es la del agua con los instrumentos de metal: el agua, tanto si está presente en el jardín de manera real como figurada a través de la piedra y/o la arena, se expresa con instrumentos metálicos en todas las piezas a excepción de la cuarta, donde Saariaho elige la electrónica. Esta ruptura del patrón resulta altamente significativa, ya que el jardín de Ryōan-ji es el único compuesto únicamente por arena y piedra (y algo de musgo) y la única pieza donde no se emplean alturas determinadas ni instrumentos de parche y sí aparecen los platos zen. El jardín más relevante desde el punto de vista del zen, y la pieza más insólita de la obra, no ocupa el cuarto lugar de un grupo de seis por casualidad: esto obedece a la búsqueda de la ruptura de la simetría en la estructura de la obra.

El agua y el metal van pues unidos así como los colores negro y blanco que representan (asociados en el gris de la arena) y encarnan el origen de la vida y lo inmaterial; esta dualidad resulta una cualidad generadora del vacío a nivel instrumental. Los instrumentos de metal siempre son representaciones del elemento agua y, por tanto, presentan una unidad indisoluble que contiene dos principios opuestos: el metal que se asocia al color blanco y al vacío, y el agua que se asocia al color negro; de esta forma, el empleo de los instrumentos de metal deviene en una alusión constante al principio del vacío.

El elemento tierra no siempre aparece y además es cambiante: cuando está, es representado por la pandereta al simbolizar la mediación entre lo terrenal y lo espiritual, o bien es representado por el tambor de hendidura o el timbal si va unido al elemento madera.

El elemento de la madera generalmente se asocia con los instrumentos construidos de este material, como el tambor de hendidura o la caja china. Este elemento y, por ende, los instrumentos que 
lo simbolizan encarnan la contraposición simbólica de lo inmaterial en el agua y el metal; su uso se basa en dicha contraposición en las piezas I, IV y V.

Por último, el fuego solo aparece puntualmente en las piezas I y III encarnado en el timbal (que casi siempre aparece asociado a los árboles) como personificación de arces y cerezos. En la siguiente tabla pueden visualizarse las principales asociaciones instrumentales descritas:

Tabla 18. Asociaciones simbólicas instrumentales predominantes en la obra

\begin{tabular}{|c|c|c|c|}
\hline Instrumentos & Elemento & Color & Simbología \\
\hline \multicolumn{4}{|l|}{ Triángulo } \\
\hline \multicolumn{4}{|l|}{ Plato metálico } \\
\hline \multicolumn{4}{|l|}{$\begin{array}{l}\text { Plato suspendido } \\
\text { Plato suspendido pequeño }\end{array}$} \\
\hline Plato suspendido pequeño & Agua - Metal & Gris (blanco y negro) & Lo inmaterial \\
\hline \multicolumn{4}{|l|}{ Crótalos (no afinados) } \\
\hline \multicolumn{4}{|l|}{ suspendidos } \\
\hline \multicolumn{4}{|l|}{ Platos zen } \\
\hline \multicolumn{4}{|l|}{ Gongs } \\
\hline \multicolumn{4}{|l|}{ Crótalos (afinados) } \\
\hline \multicolumn{4}{|l|}{ Tam-tam } \\
\hline \multicolumn{4}{|l|}{ Caja cbina } \\
\hline Tambor de bendidura & Madera & Verde & Lo material \\
\hline \multicolumn{4}{|l|}{ Tambor chino } \\
\hline Pandereta & Tierra & Amarillo & Mediador entre el cielo y la tierra \\
\hline \multicolumn{4}{|l|}{ Piedras } \\
\hline Timbales & Fuego y Madera & Rojo y Verde & Lo material \\
\hline
\end{tabular}

Cerrando los principios de la dualidad y la simbología, hay que hacer especial mención al concepto de asimetría como principio de equilibrio: este se traduce en la música de Saariaho en ciertos procesos como los descritos en la pieza $\mathrm{V}$ y a nivel estructural con la realización tan particular de la pieza número cuatro. Pero sobre todo, tiene una dimensión numerológica: el número tres es tomado como referencia constructiva en prácticamente toda la obra, desde el número de instrumentos en las agrupaciones hasta el número de figuras que conforman las células motívicas, el número de repeticiones de un elemento o la elección de las figuras de valor irregular.

Para cerrar esta investigación, solo resta enumerar posibles vías de indagación para el futuro; como prospectiva para este trabajo es de reconocer que han quedado numerosas direcciones sin explorar; por ejemplo, solamente la simbología es un terreno interpretativo fácilmente tendente al infinito. La obra de Saariaho está dedicada al compositor japonés Toru Takemitsu, autor que cuenta con su propia simbología inserta en su universo musical; una interesante vía de trabajo sería el establecimiento de los lugares de contacto y divergencia entre los puntos de vista y técnicas de ambos 
compositores. Incluso sin salir del ámbito de la obra de la propia compositora finlandesa, esta cuenta con otras piezas basadas en jardines: a partir de aquí se abren direcciones ignotas, como la comparativa entre la visión musical de un jardín oriental y uno occidental o la inserción de estas obras en el marco de su producción y evolución estilística.

En definitiva, este trabajo trata de establecer un punto de partida que abra la investigación de obras concretas de la creación de Kaija Saariho así como la visión contemporánea de la hibridación de estéticas y técnicas japonesas y occidentales.

\section{REFERENCIAS}

Aracil, Alfredo, ed. Música y Jardines. Granada: Archivo Manuel de Falla, 2003.

Auner, Joseph. La música en los siglos XX y XXI. Traducción de Juan González Castelao. Madrid: Akal, 2017.

Baridon, Michel. Los jardines. Paisajistas, jardineros, poetas. Traducción de Juan Calatrava. Madrid: Abada, 2004.

Barreiro, Carlos. «La compositora filandesa Kaija Saariaho. Música que llega del frío». Artes, La Revista 13, n. ${ }^{\circ} 7$ (2007): 44-50. https://dialnet.unirioja.es/descarga/articulo/2365699.pdf.

Berlin, Kimon. «Tenryūji». Flickr.com. 25 de octubre de 2013. https://www.flickr.com/photos/ kimon/11096238195/sizes/1/.

. «Tenryū-ji». Flickr.com. 25 de octubre de 2013. https://www.flickr.com/photos/ kimon/11096331744/.

Cabañas de Moreno, Pilar. «Un puente entre la tradición y el arte contemporáneo. El jardín japonés». Anales de Historia del Arte 12 (2002): 239-257. revistas.ucm.es/index.php/ANHA/article/ viewFile/ANHA0202110239A/31316.

Chevalier, Jean, dir. Diccionario de los simbolos. Traducción de Manuel Silvar y Arturo Rodríguez. Barcelona: Herder, 1986.

[cipher]. «Saiho-ji temple». Flickr.com. 19 de noviembre de 2015. https://www.flickr.com/photos/ h4ck/23182107986/.

Cirlot, Juan Eduardo. Diccionario de simbolos. Barcelona: Labor, 1992. 
clio1789. «Ryōan-ji». Flickr.com. 21 de noviembre de 2012. https://www.flickr.com/photos/ clio1789/8240124400/.

Cohen, Elizabeth R. «Kaija Saariaho. Six Japanese gardens». INART55 (2004). http://www.personal.psu. edu/meb26/INART55/pastpapers/sixjapgdns.pdf.

Colás, Ma Pilar y Leonor Buendía. Investigación Educativa. Sevilla: Alfar, 1998.

De los Ríos, Ángel. «Ryōan-ji». Flickr.com. 13 de octubre de 2019. https://www.flickr.com/photos/ diocrio/49477285897.

Di Santo, Jean-Louis. «Six Japanese gardens by K. Saariaho: eastern and western temporalities». Proceedings of the Electroacoustic Music Studies Network Conference (EMS17) (2017). http://www. ems-network.org/IMG/pdf EMS17 DiSanto.pdf.

Díaz de la Fuente, Alicia. «El sonido de Kaija Saariaho». Música. Revista del Real Conservatorio de Música de Madrid 23 (2016): 153-164. https:rcsmm.eu/general/files/revista/revista23.pdf.

Ensemble Musikfabrik. «John Cage. Ryoanji». Vídeo de YouTube, 23:48. Publicado el 21 de agosto de 2014. https://www.youtube.com/watch?v=TNP3kuu9xvw.

Equipo Superprof. «Superprof». Acceso el 7 de febrero de 2021. https://www.superprof.es/blog/ cronologia-historia-japon/.

Eric'T. «InSaiho-ji».Flickr.com.26 de julio de 2013.https://www.flickr.com/photos/ericts/9371229593/.

Fahr-Becker, Gabriele. Arte asiático. Traducción de Ambrosio Berasain Villanueva, Alejandra Carretón Schreppel, Maria Dolors Gonzálvez Playà y Ramon Monton i Lara. AmPotsdam: Ullman, 2011.

Fariello, Francesco. La arquitectura de los jardines. De la Antigüedad al siglo XX. Traducción de Jorge Sainz. Barcelona: Reverte, 2004.

Fuji, Mihoyo. «Saihoji kokedera karesansui2». Flickr.com. 11 de julio de 2017. https://www.flickr.com/ photos/157604126@N05/36514366805/.

Fundació Joan Miró. «Fundació Joan Miró». Acceso el 10 de febrero de 2021. https://www.fmirobcn. org/es/.

Gracia, Carmen. «La Tierra Pura, el fin del Dharma y la mirada al paisaje: Una introducción a los orígenes del jardín japonés». Saitabi. Revista de la Facultad de Geografía e Historia 57 (2007): 127147. https://ojs.uv.es/index.php/saitabi/article/view/6217/5974. 
Gras, Menene, dir. El jardín japonés: qué es y qué no es entre la espacialidad y la temporalidad del paisaje. Madrid: Tecnos, 2015.

Guilloret, Annie. «Kyoto Kokodera Saiho-ji Temple de mousses». Flickr.com. Diciembre de 2013. https://www.flickr.com/photos/nahemaparis/21723315679/.

Howell, Tim, ed. Kaija Saariaho: Visions, Narratives, Dialogues. Oxford: Routledge, 2011.

joevare. «Tenju-an 04». Flickr.com. 15 de noviembre de 2010. https://www.flickr.com/photos/ joevare/5216603418/sizes/1/.

Kaden, Christian. «Kokedera - the Temple of Moss». Flickr.com. 10 de septiembre de 2012. https:// www.flickr.com/photos/satorinihon/8015672117/.

. «Kokedera - the Temple of Moss». Flickr.com. 10 de septiembre de 2012. https://www.flickr. com/photos/satorinihon/8015679032/.

Kyoko y Jesús. «Japonpedia». Acceso el 8 de febrero de 2021. https://japonpedia.com/templo-doradokioto-kinkakuji/.

Lizarralde, Mikel. «Kinkaku-ji». Flick.r.com. 1 de agosto de 2008. https://www.flickr.com/photos/ mikeltxo/2730848083/

mattlucht. «Ryoanji Temple zen garden (2)». Flickr.com. 5 de octubre de 2011. https://www.flickr.com/ photos/mattlucht/6213863279/.

Mennerich, Daniel. «Kyoto J - Kinkaku-ji - Great Pond». Flickr.com. 5 de mayo de 2015. https://www. flickr.com/photos/danielmennerich/24549139674/

Meyer, Bardley Edward. «Six Japanese Gardens and Trois Rivières: Delta: An analysis of Kaija Saariaho’s two major works for solo percussion and electronics». Tesis doctoral. Universidad de Kentucky, 2011. https:/ / uknowledge.uky.edu/cgi/viewcontent.cgi?article $=1188 \&$ context $=$ music etds.

Michel, Pierre; Ivanka Stoïanova y Damiel Pousset. Kaija Saariaho. París: IRCAM, 2014.

Micklea, Brad. «Daisen-in_Zen_Garden». Flickr.com. 1 de noviembre de 2014. https://www.flickr. com/photos/bradmicklea/15659472876/.

Moisala, Pirkko. Kaija Saariaho. Cahmpaign, IL: University of lllinois Press, 2009.

Montavion, Alexia. «Torii, Itsukushima-jinja». Flickr.com. 20 de julio de 2015. https://www.flickr.com/ photos/alan736/28086495464. 
Nippon.com. «Nippon.com. Una ventana a Japón». Acceso el 7 de febrero de 2021. https://www. nippon.com/es/in-depth/a05403/.

Nitschke, Gunter. El jardín japonés. El ángulo recto y la forma natural. Traducción de Carmen Sánchez Rodríguez. Koln: Taschen, 2003.

Okakura, Kakuzo. El libro del té. La ceremonia del té japonesa (Cha no Yu). Traducción de José Javier Fuente del Pilar. Madrid: Miraguano, 2012.

Palacios, $\mathrm{M}^{a}$ Dolores. «Patrimonio y paisaje en Japón». Axa. Una revista de Arte y Arquitectura 7 (2015): 1-15. https://revistas.uax.es/index.php/axa/article/view/1141/935.

Paul Sacher Foundation. «Kaija Saariaho». Acceso el 5 de febrero de 2021. https://saariaho.org/.

Pedragosa, Francesc. «Interior/exterior en el espacio arquitectónico japonés». DPA: Documents de Projectes d'A Arquitectura, 13 (1997): 16-21. https://upcommons.upc.edu/handle/2099/12157.

Quintanal, José y Begoña García Domingo, coords. Fundamentos Básicos de Metodología de Investigación Educativa. Madrid: editorial CCS, 2012.

Ryoanji Temple. «Ryoanji». Acceso el 8 de febrero de 2021. http://www.ryoanji.jp/smph/eng/.

Saariaho, Kaija. Six Japanese Gardens [partitura]. Londres: Chester Music LTD, 1994. . Kaija Saariaho. Oewvres dédiées. Thierry Miroglio, percusión. INA-GRM, 2002, CD.

SAIHOJI. «Saihoji». Acceso el 9 de febrero de 2021. http://saihoji-kokedera.com/en/top.html.

Schauwecker, Stefan. «Japan-Guide». Acceso el 7 de febrero de 2021. https://www.japan-guide. com/e/e3905.html.

Shane Jones. «Six Japanese Gardens - Kaija Saariaho». Vídeo de YouTube, 15:58. Publicado el 26 de enero de 2017. https://www.youtube.com/watch?v=x7t-n3EDqpM.

Suzuki, Daisetz. El zen y la cultura japonesa. Traducción de María Tabuyo y Agustín López. Barcelona: Paidós, 1996.

tablexxnx. «Tenryū-ji». Flickr.com. 13 de diciembre de 2016. https://www. Alickr.com/photos/ tablexxnx/31080795863/.

Terao, Eriko. «El jardín japonés como microcosmos. Lo invisible en el jardín japonés». Galicia y Japón: del sol naciente al sol poniente. IX Encuentros internacionales de filosofía en el Camino de Santiago (2009): 229-240. https://ruc.udc.es/dspace/handle/2183/12904. 
tiarescott. «Japan-Kyoto-Daitoku-ji-zen-buddhist-temple-Daisen-in-Japan-Inland-Sea-April-2004». Flickr.com. 2 de abril de 2004. https://www.flickr.com/photos/tiarescott/33507966/.

UNESCO en español. «El teatro Kabiku». Vídeo de YouTube, 04:23. Publicado el 29 de septiembre de 2009. https://www.youtube.com/watch?v $=$ G71-YMHYbQI.

Vierthaler, Patrick. «Tenju-an». Flickr.com, 26 de julio de 2016. https://www. pv9007/28080264813/.

. «Tenju-an in Autumn». Flickr.com. 10 de noviembre de 2016. https://www.flickr.com/photos/ pv9007/30259219434/sizes/1/.

.«Kinkaku».Flickr.com. 9 de mayo, 2019. https://www.flickr.com/photos/pv9007/49878060117/ sizes $/ 1 /$.

Vives, Javier. Historia y arte del jardín japonés. Gijón: Satori Ediciones, 2014.

Wellesz Opus. «Kaija Saariaho: Six Japanese Gardens (1994)». Vídeo de YouTube, 18:53. Publicado el 7 de febrero de 2015. https://www.youtube.com/watch?v=bQLA4cUv1IQ.

Wilson Loo Kok Wee. «Kyoto. Daisen-in». Flickr.com. 29 de junio de 2008. https://www.flickr.com/ photos/kwloo/3788055824/.

- «Kyoto. Daisen-in». Flickr.com. 29 de junio de 2008. https://www. flickr.com/photos/ kwloo/3788059402/.

Winterfeldt, Susanne, ed. Kaija Saariaho. Berlín: Musikfrauen, 1991. 